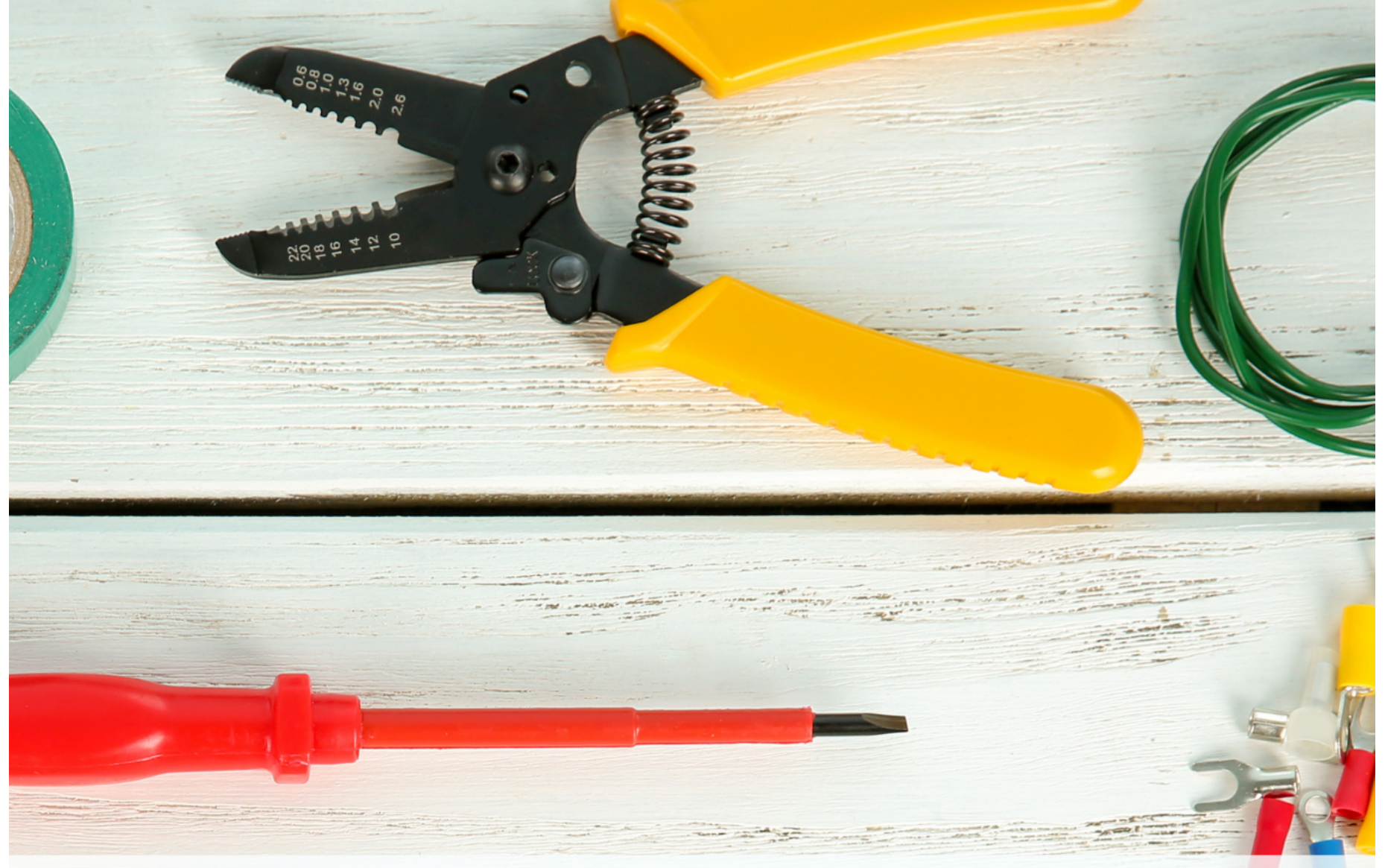

\title{
TÓPICOS EM ENGENHARIA
}

\section{ELÉTRICA E ELETRÔNICA}

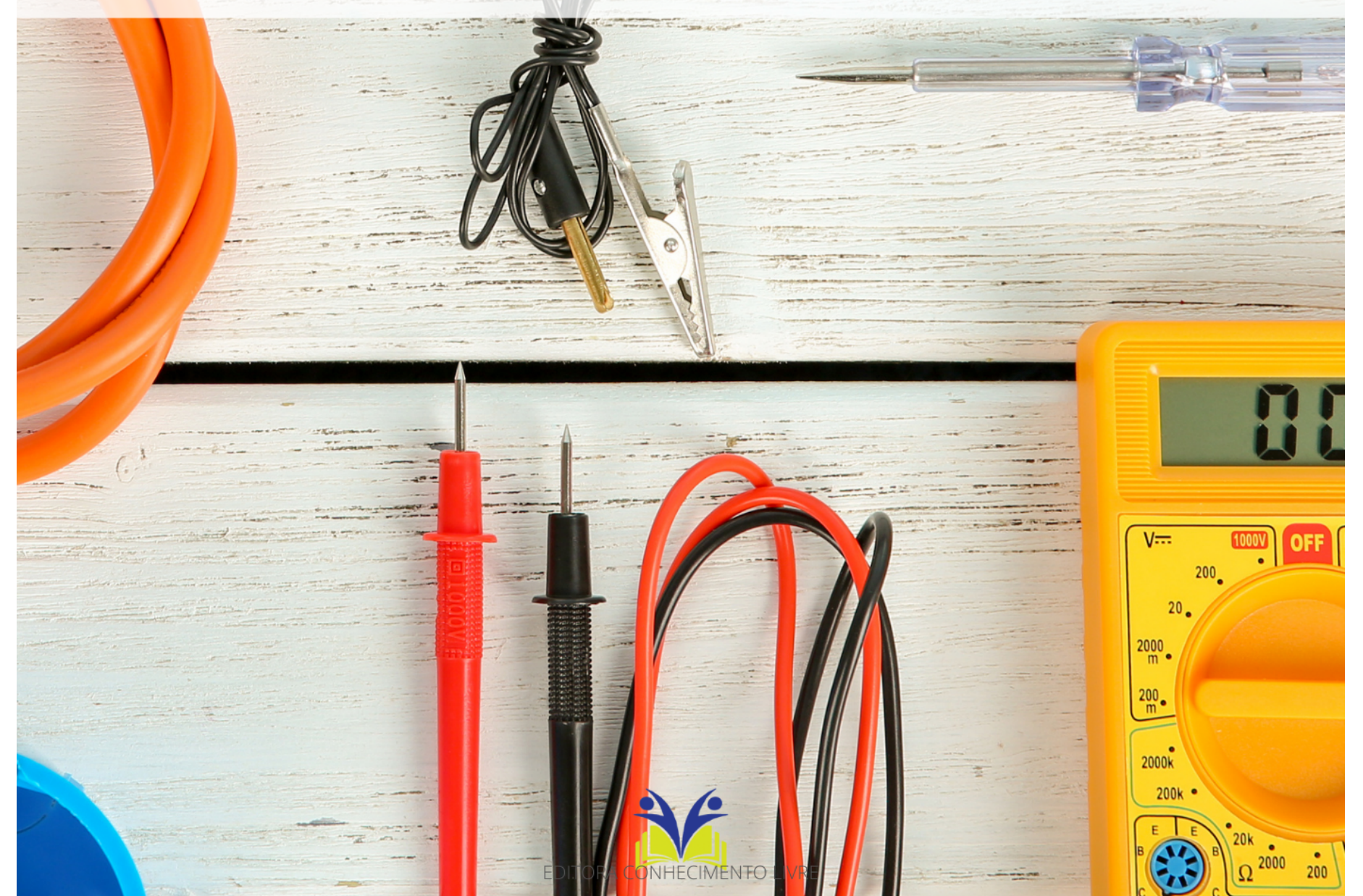


Frederico Celestino Barbosa

Tópicos em engenharia elétrica e eletrônica

$1^{\text {a }}$ ed.

Piracanjuba-GO

Editora Conhecimento Livre

Piracanjuba-GO 
$1^{\mathrm{a}} \mathrm{ed}$

\section{Dados Internacionais de Catalogação na Publicação (CIP)}

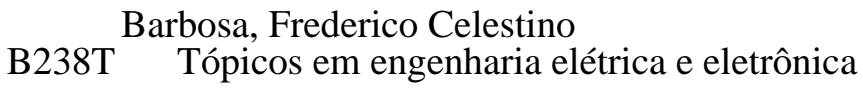

/ Frederico Celestino Barbosa. - Piracanjuba-GO

Editora Conhecimento Livre, 2021

112 f.: il

DOI: $10.37423 / 2021$.edcl366

ISBN: 978-65-5367-004-4

Modo de acesso: World Wide Web

Incluir Bibliografia

1. transmissão 2. geração 3. circuitos 4. produtos 5. sistemas I. Barbosa, Frederico Celestino II.

Título

CDU: 620

https://doi.org/10.37423/2021.edc1366

O conteúdo dos artigos e sua correção ortográfica são de responsabilidade exclusiva dos seus respectivos autores. 


\title{
EDITORA CONHECIMENTO LIVRE
}

\section{Corpo Editorial}

\author{
Dr. João Luís Ribeiro Ulhôa \\ Dra. Eyde Cristianne Saraiva-Bonatto \\ MSc. Frederico Celestino Barbosa \\ MSc. Carlos Eduardo de Oliveira Gontijo \\ MSc. Plínio Ferreira Pires
}




\section{SUMÁRIO}

CAPÍTULO 1 5

ANÁLISE DA ESTABILIDADE ANGULAR TRANSITÓRIA EM UM SISTEMA TESTE COM ALTA PENETRAÇÃO DE GERAÇÃO EÓLICA

Vitor Gabriel Soares Santos

Ivan Paulo de Faria

Aurélio Luiz Magalhães Coelho

Élcio Franklin de Arruda

DOI 10.37423/211104992

CAPÍTULO 2

ATTITUDE ESTIMATION USING A TWO-STEP UNSCENTED APPROACH WITH GYRO BIAS

ESTIMATION AND ACCELERATION CORRECTION

Guilherme Silva Terra

Leonardo A. B. Torres

Bruno O.S. Teixeira

DOI 10.37423/211104996

CAPÍTULO 3

ESTABILIZAÇÃO DE UM PÊNDULO INVERTIDO USANDO CONTROLADOR H2 CONTÍNUO ADRIANO BRUNO FRUTUOSO

ANDRÉ HENRIQUE SANTOS

DIEGO CÂMARA SALES

DOI 10.37423/211105005

CAPÍTULO 4

SISTEMA DE GERAÇÃO DE ENERGIA EÓLICA COM FILTRO ATIVO PARALELO A PARTIR DO GERADOR SÍNCRONO DE IMÃ PERMANENTE CONECTADO À REDE ELÉTRICA

Leonardo Pires de Sousa Silva

Denisia de Vasconcelos Mota

Levy Rodrigues Cavalcante

Lucas Taylan Pontes Medeiros

Vanessa Siqueira de Castro Teixeira

Adson Bezerra Moreira

DOI 10.37423/211105008

CAPÍTULO 5

ÁLGEBRA DE CLIFFORD APLICADA A ANÁLISE DA POTÊNCIA ELÉTRICA EM SISTEMAS MONOFÁSICOS SOB CONDIÇÕES NÃO SENOIDAIS.

Rafael Furquim Junior

Niraldo Roberto Ferreira

Fernando Augusto Moreira

DOI 10.37423/211105026 
COMPARAÇÃO DE CLASSIFICADORES NA ANÁLISE DE GASES DISSOLVIDOS José Jorge de Oliveira Neto

George Victor Rocha Xavier

Diego Oliveira Cardoso

Jânio Coutinho Canuto

DOI 10.37423/211105064 


\section{Capítulo 1}

\section{doi $10.37423 / 211104992$}

\section{ANÁLISE DA ESTABILIDADE ANGULAR TRANSITÓRIA EM UM SISTEMA TESTE COM ALTA PENETRAÇÃO DE GERAÇÃO EÓLICA}

Vitor Gabriel Soares Santos

Ivan Paulo de Faria

Aurélio Luiz Magalpães Cgêhe

Élcio Franklin de Aruda

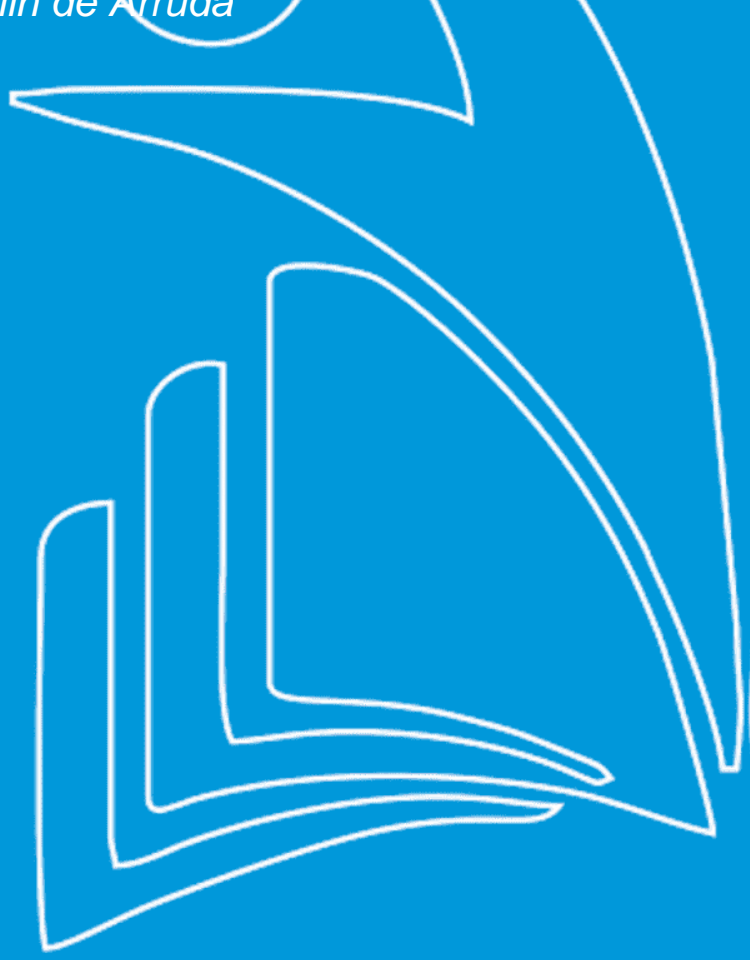

Universidade Federal de Itajubá

Universidade Federal de Itajubá

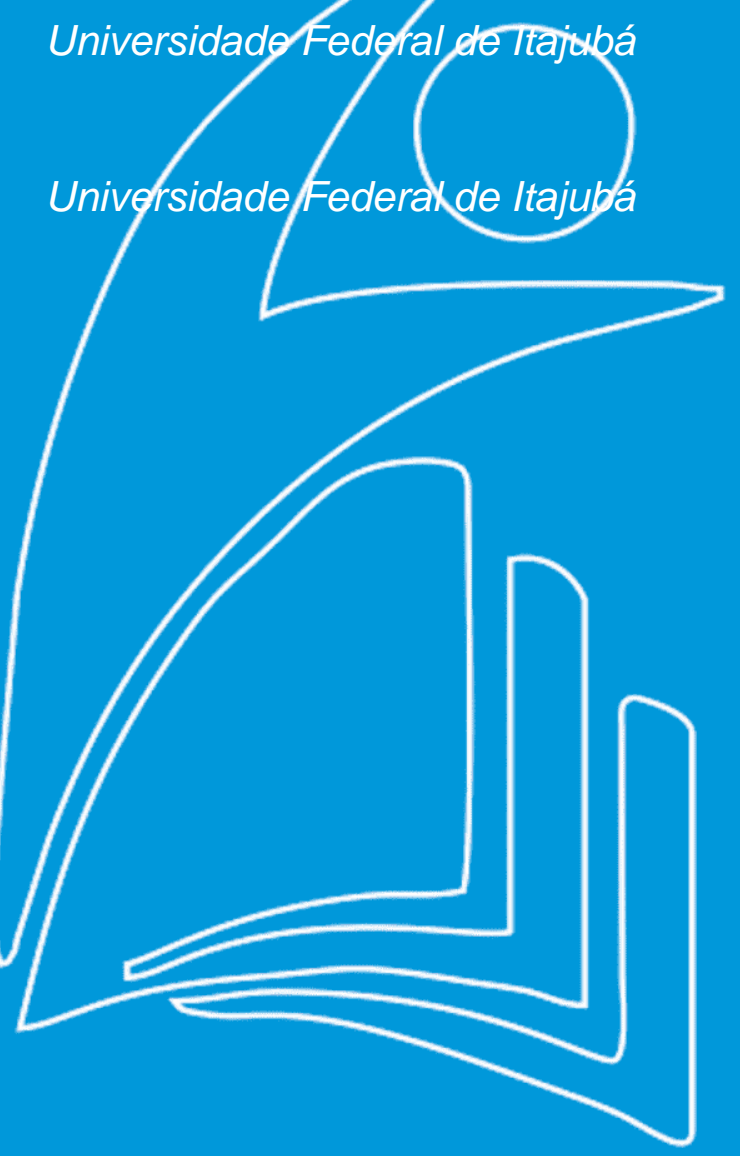


Resumo: Com o contínuo crescimento das integrações de novas usinas eólicas no sistema interligado nacional, o impacto da alta penetração desse tipo de geração na estabilidade do sistema se torna uma questão muito importante. Nesse sentido, esse trabalho apresenta um estudo de caso sobre a influência da penetração de aerogeradores na estabilidade angular transitória de um sistema equivalente da região sul do Brasil. Devido à instabilidade causada pela presença de aerogeradores, observada em alguns casos, propôs-se a instalação de resistores de frenagem. $\mathrm{O}$ dimensionamento dos resistores, o local de sua instalação e a resposta do sistema para diferentes pontos de falta são investigados. Os resultados mostraram que houve uma redução de $40 \%$ do número de desligamentos de usinas, para os casos simulados, considerando a presença do resistor de frenagem, mostrando que essa é uma boa solução para melhoria da estabilidade eletromecânica de sistemas interligados.

Palavras-chaves: Estabilidade; Geração eólica; Resistor de frenagem; Oscilações; Amortecimento. 


\section{INTRODUÇÃO}

De acordo com o Boletim Mensal de Geração Eólica de abril de 2019, explanado pelo Operador Nacional do Sistema Elétrico (ONS), o Brasil possui cerca de 14,1 GW de capacidade instalada de usinas eólicas em operação comercial no Sistema Interligado Nacional (SIN) (ONS, 2019). Para a mesma data a Agência Nacional de Energia Elétrica (ANEEL) apresenta que a capacidade de geração total do país é cerda de $164 \mathrm{GW}$ de potência instalada, aos quais aproximadamente 9,14\% são de origem da energia cinética do vento (ONS, 2019).

Ao comparar os relatórios do ONS de abril de 2014 (ONS, 2014) e 2019 (ONS, 2019), observa-se que houve um aumento de quase $14 \mathrm{GW}$ da capacidade de geração dessa fonte. O Plano de Ampliações e Reforços nas Instalações de Transmissão do SIN de novembro de 2018 prevê um aumento da geração eólica para os próximos quatro anos, chegando a 16,7 GW em 2023 (ONS, 2018). Esse relatório cita a necessidade de garantir qualidade e confiabilidade do sistema para esse tipo de geração, bem como equipamentos de controle que proporcionem inércia sincronizada para assegurar a estabilidade do SIN.

Um sistema de potência pode ser dito como estável caso se mantenha em estado de equilíbrio durante a operação, mesmo após sofrer algum distúrbio (Kundur, 1994). Com o aumento da integração da energia eólica nos sistemas interligados somada à crescente demanda por energia, o impacto da penetração dos parques eólicos na estabilidade angular tem se tornado uma preocupação para a operação do sistema e, portanto, alvo de estudo de vários pesquisadores (Edrah et al., 2015).

A instalação de resistores de frenagem tem sido utilizada para prover melhorias na estabilidade angular transitória na presença de fontes eólicas, pois esta é uma das formas que apresenta um bom custo-benefício para o amortecimento das oscilações eletromecânicas. Nesse sentido, diversos trabalhos têm relatado a utilização desse equipamento.

Robak e Gryszpanowicz (2018) realizam uma análise do dimensionamento do resistor de frenagem quanto esse equipamento é conectado em série com o sistema. Os autores do trabalho propuseram uma formulação matemática para o cálculo do resistor, que leva em conta a reatância do transformador elevador do parque eólico e a reatância subtransitória dos geradores. Tal dimensionamento busca a condição de máxima dissipação de potência no resistor de frenagem, que tem como objetivo minimizar a potência acelerante durante perturbações no sistema. 
Posteriormente, Robak et al. (2019) propuseram um algoritmo, baseado em medições locais de potência ativa e corrente, para a escolha do momento em que o resistor série deve ser desconectado do sistema. Pelo algoritmo proposto, os autores do trabalho concluíram que foi possível aumentar o tempo crítico para eliminação de curtos-circuitos sem causar a instabilidade angular do sistema analisado. Os resultados obtidos são importantes quando se considera a falha do disjuntor na abertura da corrente de curto-circuito ou, até mesmo, a falha na identificação da falta pelo sistema de proteção em zona 1, sendo que ambos os casos elevam o tempo de eliminação do defeito.

No estudo de Naimi e Bouktir (2008) são avaliadas as influências que os graus da geração eólica provocam no tempo crítico de eliminação do defeito para ocorrência de uma falta trifásica no sistema. Tanto no trabalho de Qiao e Harley (2008), quanto de Vittal et al. (2012), os estudos têm o foco na interação da estabilidade angular do rotor e a produção de potência reativa para altas penetrações de geração eólica. No estudo apresentado por Edrah et al. (2015), são analisadas diferentes estratégias de controle no Gerador de Indução Duplamente Alimentado para o amortecimento das oscilações eletromecânicas.

Okedu (2020) investigou, em seu trabalho, o desempenho transitório de geradores de indução duplamente alimentado na presença de resistor série de frenagem do tipo dinâmico. 0 dimensionamento, a localização ótima entre estator, rotor ou diretamente instalado na rede, o tempo de inserção e a permanência do resistor foram investigados frente a ocorrência de um curto-circuito trifásico no sistema. O autor do trabalho conclui que a instalação do resistor de frenagem do lado do estator do gerador apresentou melhores respostas dinâmicas para as grandezas analisadas.

Portanto, esse trabalho tem por objetivo realizar um estudo de caso em um sistema equivalente sul do Brasil, considerando a inserção de geração eólica. Para minimizar as oscilações eletromecânicas quando das ocorrências de curtos-circuitos no sistema, é proposta a instalação de resistores série de frenagem. Buscou-se analisar a influência da instalação dos resistores em diferentes pontos do sistema, bem como, a resposta dinâmica para diferentes localizações de falta. Os resultados mostram que mesmo para uma lógica simples de inserção do resistor série, é possível obter melhorias na estabilidade angular transitória do sistema analisado, com redução de desconexão de usinas em $40 \%$ quando comparado ao sistema sem a presença do resistor de frenagem.

As próximas sessões do trabalho estão organizadas em apresentar o modelo do gerador eólico utilizado, mostrar o dimensionamento do resistor de frenagem, descrever o sistema teste simulado, apresentar os resultados e discussões e a conclusão do trabalho. 


\section{MODELO DA MÁQUINA EÓLICA}

O programa ANATEM possui diferentes esquemas de representação da geração eólica. Neste estudo, faz-se o uso do Gerador de Indução Duplamente Alimentado (GIDA), que passou a ser bastante utilizado devido e sua capacidade de gerar potência elétrica constante (Barbosa, 2017). Para as análises, utilizou-se da modelagem do aerogerador GIDA disponibilizado pelo programa. Tal escolha foi feita devido à complexidade nos detalhes e a necessidade de uma maior aproximação de um caso real. Com isso, na Tabela 1 é possível ver alguns dados referentes à inicialização do modelo de uma unidade de GIDA utilizada.

Tabela 1. Dados básicos referentes a uma unidade GIDA utilizada.

\begin{tabular}{|c|c|}
\hline Descrição & Valor \\
\hline Raio das pás & $29 \mathrm{~m}$ \\
\hline Frequência nominal do estator & $60 \mathrm{~Hz}$ \\
\hline Potência em cada unidade & $833,33 \mathrm{~kW}$ \\
\hline Potência base do gerador & $850 \mathrm{~kW}$ \\
\hline Velocidade do vento & $11,50 \mathrm{~m} / \mathrm{s}$ \\
\hline Velocidade de referência & $1,08 \mathrm{pu}$ \\
\hline Coeficiente de desempenho & 0,3386 \\
\hline
\end{tabular}

\section{RESISTORES DE FRENAGEM}

De acordo com Robak e Gryszpanowicz (2018), resistores de frenagem podem atuar de forma externa aos geradores, em série ou paralelo à linha de transmissão. Além disso, esse método pode ser instalado na planta geradora, para amortecimentos locais na usina, ou nas linhas de transmissão, para aumentar o amortecimento interáreas. Neste estudo é utilizado o resistor disposto em série ao sistema e para amortecimentos interáreas. Um exemplo de sua disposição no sistema pode ser visto na Fig. 1.

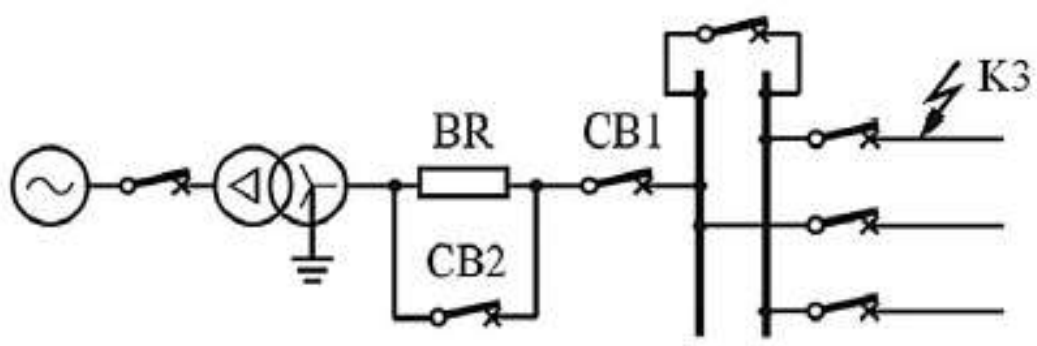

Fig. 1: Diagrama de chaveamento do resistor de freio (BR) com instalação série (adaptado de Robak e Gryszpanowicz, 2018). 
De acordo com a Fig. 1, para atuação do resistor de frenagem BR, a chave CB2 é aberta, inserindo o resistor no sistema. Para desconectá-lo do circuito, a chave CB2 é fechada. O valor a ser adotado pela resistência de forma a modificar a característica do amortecimento angular do sistema é obtido a partir de (1) (Robak e Gryszpanowicz, 2018).

$$
R \leq\left(\begin{array}{lll}
1 & a & 1,1
\end{array}\right) \cdot\left(X_{d}^{\prime \prime}+X_{T}\right)
$$

Tal que R é o valor da resistência, $X_{d}^{\prime \prime}$ é a reatância subtransitória do gerador e ${ }_{t}$ a reatância do transformador elevador.

\section{DESCRIÇÃO DO SISTEMA TESTE}

Para a análise do impacto da penetração de geração eólica, as simulações foram realizadas no Sistema Teste Brasileiro de 33 Barras (STB-33) (Alves, 2007). O sistema possui diversas linhas de transmissão e transformadores de potência, com malhas de $500 \mathrm{kV}$ e $230 \mathrm{kV}$ e sete usinas hidrelétricas. O diagrama representativo do sistema e a indicação do local ao de inserção do parque eólico podem ser vistos na Fig. 2.

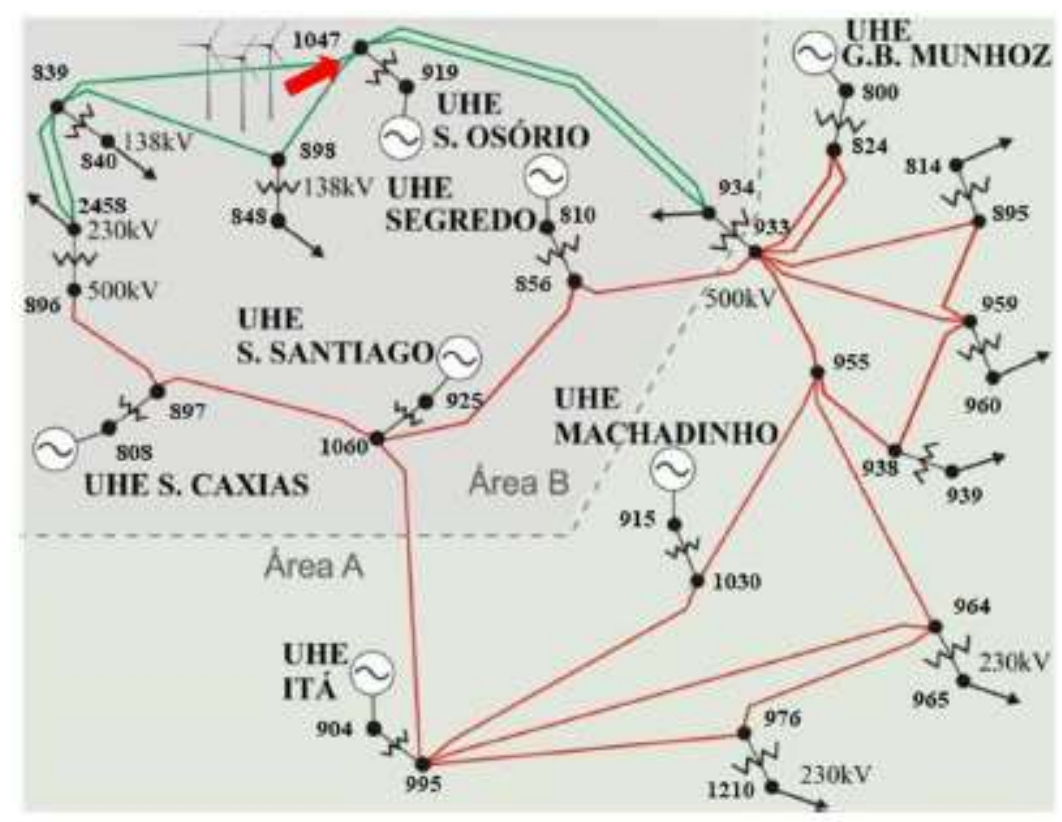

Fig. 2 STB-33, diagrama unifilar (adaptado de Alves, 2007).

Este sistema possui um valor de carga total de $4845 \mathrm{MW}$ e $1141 \mathrm{Mvar}$, distribuídas ao longo dos barramentos de carga.

Na Tabela 2, é possível observar o número de máquinas presente em cada usina hidrelétrica, bem como a capacidade de geração de cada uma delas. Vale destacar que todas as máquinas geradoras são 
modeladas considerando as respectivas malhas de controle, como reguladores automáticos de tensão, excitatrizes, reguladores de velocidade, turbina e sinais estabilizantes de potência (PSS), importados da base de dados dinâmicos do ONS referentes à junho de 2009.

Tabela 2. Capacidade de geração de potência ativa, em MW, do STB-33.

\begin{tabular}{|c|c|c|}
\hline $\begin{array}{c}\text { Usina } \\
\text { Hidrelétrica }\end{array}$ & $\begin{array}{c}\mathrm{N}^{\circ} \text { de } \\
\text { máquinas }\end{array}$ & $\begin{array}{c}\text { Geração } \\
\text { Máxima [MW] }\end{array}$ \\
\hline G. B. Munhoz & 4 & 1674 \\
\hline Salto Santiago & 4 & 1420 \\
\hline Salto Osório & 4 & 728 \\
\hline Salto Segredo & 4 & 1260 \\
\hline Salto Caxias & 4 & 1240 \\
\hline Itá & 5 & 1450 \\
\hline Machadinho & 3 & 1140 \\
\hline
\end{tabular}

\section{METODOLOGIA}

Para um maior entendimento relacionado à estabilidade angular e as influências da inserção de geração eólica, o STB- 33 é submetido a diversas perturbações. A maior parte dos casos estudados refere-se a um curto-circuito trifásico franco com duração de 240 ms na barra 1060 da Fig. 3, de 500 $\mathrm{kV}$, referente a usina de Salto Santiago, que causa a abertura da linha de transmissão que interliga a usina de Itá com a usina de Salto Santiago. A duração escolhida do curto-circuito é maior que o tempo crítico de eliminação do defeito (CCT - Critical Clearing Time) para este sistema com penetração de geração alternativa, conforme foco das análises realizadas por Naimi e Bouktir (2008).

O sistema de geração eólica é composto por diversos parques de $35 \mathrm{MW}$ agrupados de forma a obter uma geração total de $750 \mathrm{MW}$. O complexo sistema de geração eólica é modelado de acordo com as características da turbina eólica e do controle dos conversores. Os casos analisados neste trabalho são descritos as seguir.

\subsection{SISTEMA SEM GERAÇÃO EÓLICA}

Na primeira análise o STB-33 não possui geração eólica, contando apenas com as usinas geradoras iniciais.

\subsection{SISTEMA COM GERAÇÃO EÓLICA}

A segunda análise apresenta a inserção do parque eólico próximo a usina de Salto Osório com geração que corresponde a $8,41 \%$ da capacidade de geração máxima do sistema teste. A usina de 
aerogeradores é inserida na barra 1047 da Fig. 3. A fim de manter a relação de geração e carga do sistema original foram acrescidos $750 \mathrm{MW}$ de carga distribuídos igualmente em 5 pontos de carga distintos do sistema, sendo eles as barras de carga 814, 960, 939, 965 e 976.

\subsection{SISTEMA COM GERAÇÃO EÓLICA E RESISTOR DE FRENAGEM ENTRE SALTO SEGREDO E SALTO}

\section{SANTIAGO - RESISTOR 1}

Com o intuito de diminuir as oscilações eletromecânicas, é adicionado à linha de transmissão que interliga as usinas de Salto Segredo e Salto Santiago um resistor série de frenagem, por ser próximo ao ponto do sistema onde ocorre a perturbação. O resistor atua 40 ms após o início do curtocircuito e é retirado juntamente com a eliminação do surto e restabelecimento do sistema completo, como estabelecido por Robak e Gryszpanowicz (2018). O valor do resistor é de $70 \Omega$, referente à máquina geradora e o transformador de potência da usina de Salto Segredo, correspondendo às condições de (1).

\subsection{SISTEMA COM GERAÇÃO EÓLICA E RESISTOR DE FRENAGEM ENTRE MACHADINHO E ITÁ}

A usina hidrelétrica de Machadinho possui grande influência nas variações eletromecânicas do sistema. Assim, é inserido um resistor de frenagem entre as usinas de Machadinho e Itá.

O valor do resistor é de $156 \Omega$, referente ao equivalente das máquinas da usina de Machadinho de acordo com (1).

\subsection{SISTEMA COM GERAÇÃO EÓLICA E RESISTOR DE FRENAGEM ENTRE SALTO SEGREDO E SALTO SANTIAGO - RESISTOR 2}

É repetida a simulação da subseção 5.3 com a modificação no valor do resistor de frenagem. É alterado o valor da resistência para $156 \Omega$, referente ao dado encontrado na análise feita com a usina de Machadinho. Dessa forma, é possível verificar se a alteração do resistor causa um impacto positivo maior ao sistema.

\subsection{ANÁLISE DE ESTABILIDADE ANGULAR COM CURTO-CIRCUITO EM DIFERENTES BARRAS DO SISTEMA}

Sabe-se que a resposta a perturbações em um sistema se difere para curtos-circuitos aplicados em barras distintas do sistema. 
Assim, são realizadas análises com curtos-circuitos trifásicos francos de distintos tempo de duração e em barras diferentes do sistema em duas condições distintas. A primeira condição é da subseção 5.2, e a segunda condição é da subseção 5.4 .

\section{RESULTADOS E DISCUSSÕES}

As análises apresentadas referem-se a estabilidade angular das usinas hidrelétricas geradoras presentes no sistema, sendo a

Usina de Governador Bento Munhoz adotada como referência. Os resultados e discussões para cada caso são apresentados a seguir.

\subsection{SISTEMA SEM GERAÇÃO EÓLICA}

O comportamento angular das máquinas geradoras é apresentado na Fig. 3. De acordo com o ONS, o período máximo para a eliminação do defeito é de 100 ms nos sistemas de transmissão de 500 kV. No entanto, a simulação em questão possui alto tempo de duração do distúrbio ( $240 \mathrm{~ms}$ ) com o objetivo de levar a análise próximo ao limite de estabilidade em operação quando da presença de geração eólica.

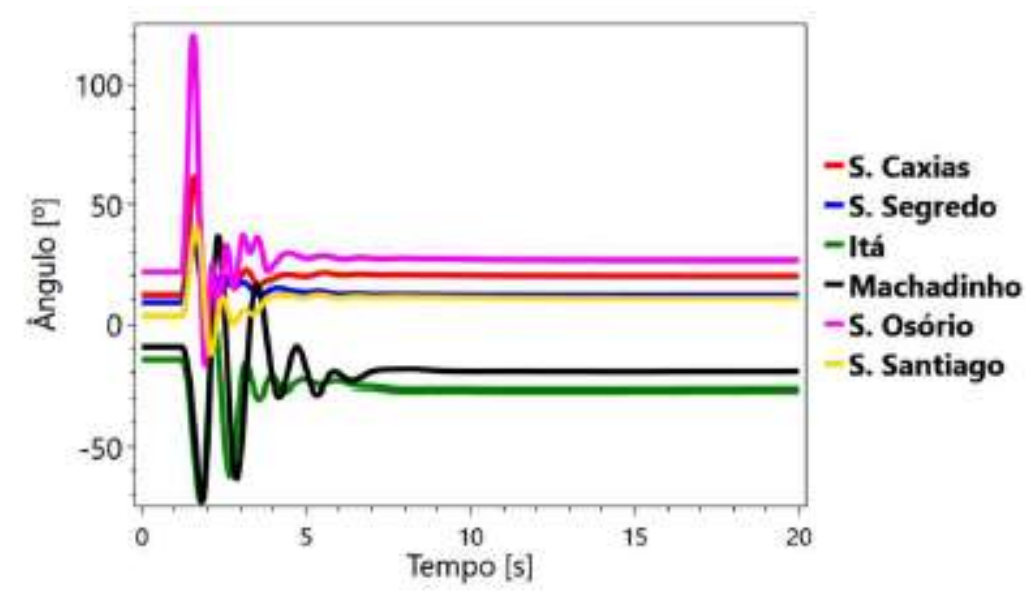

Fig. 3 Comportamento angular dos geradores sem a presença de geração eólica para um curto-circuito trifásico na barra 1060, com duração da perturbação de 240 ms.

Observa-se que houve grandes oscilações angulares iniciais nas máquinas, com destaque para a máquina de Salto Osório que atingiu cerca de $120^{\circ}$ elétricos. Apesar do longo tempo de duração do curto-circuito, o sistema manteve a estabilidade angular. 


\subsection{SISTEMA COM GERAÇÃO EÓLICA}

A Fig. 4 apresenta a resposta angular das máquinas do sistema considerando a presença dos parques eólicos na barra 1047 e ocorrência do curto-circuito trifásico na barra 1060, com eliminação do defeito em 240 ms.

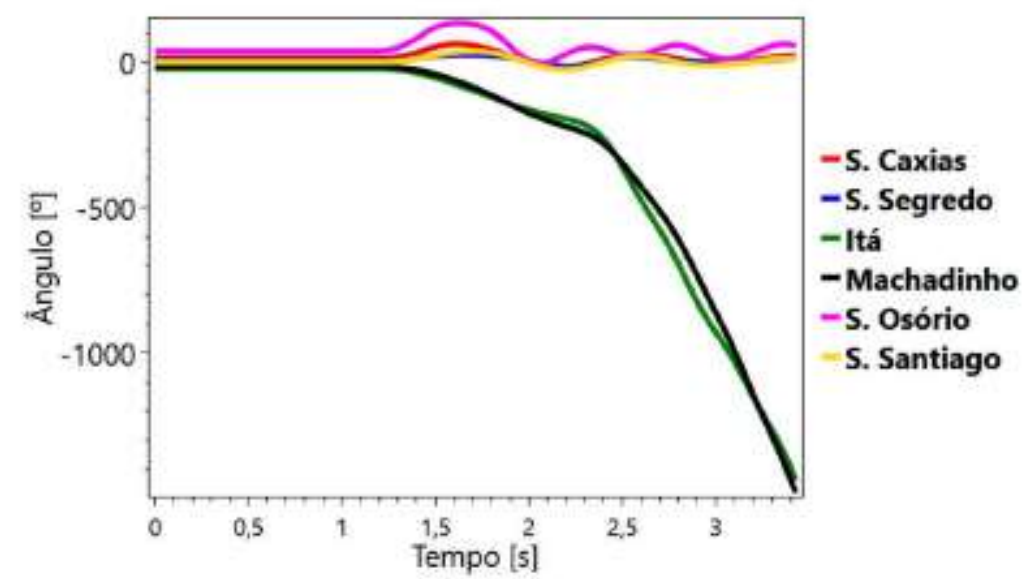

Fig. 4 Comportamento angular dos geradores com a presença da geração eólica para um curto-circuito trifásico franco na barra 1060.

Por meio da Fig. 4, observa-se que o sistema se mostrou instável após a eliminação do defeito. A instabilidade ocorre nas máquinas das usinas de Itá e Machadinho, sendo que as demais usinas mantêm a estabilidade.

\subsection{SISTEMA COM GERAÇÃO EÓLICA E RESISTOR DE FRENAGEM ENTRE SALTO SEGREDO E SALTO} SANTIAGO - RESISTOR 1

Observado o caso de instabilidade apresentado na Fig. 4, foi proposto e adicionado um resistor série de frenagem de $70 \Omega$ na linha de transmissão que interliga as usinas de Salto Segredo e Salto Santiago. A resposta do comportamento angular para este caso pode ser vista na Fig. 5. 


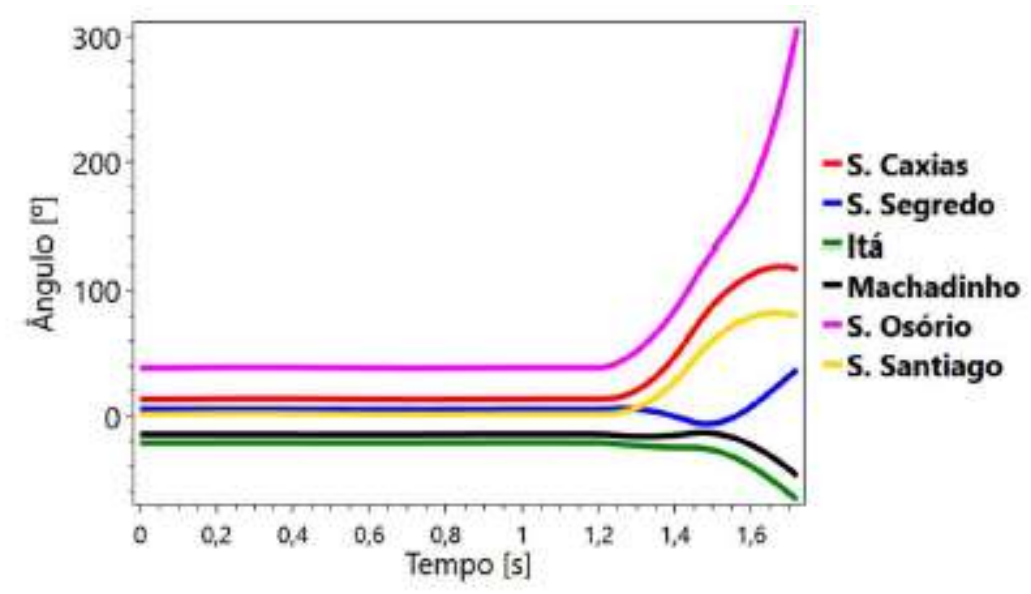

Fig. 5 Comportamento angular dos geradores com geração eólica e Resistor de Frenagem 1 entre S. Segredo e S. Santiago para um curto-circuito trifásico franco na barra 1060.

De acordo com a Fig. 5, o sistema apresentou instabilidade angular após a ocorrência da falta. A adição do referido resistor de frenagem causou, de forma contrária ao esperado, uma oscilação mais significativa nas máquinas geradoras de Salto Osório. Adicionalmente, não foram observadas melhoras quanto a estabilidade do sistema. Dessa forma, apesar do método de amortecimento ser utilizado, a resposta obtida não foi satisfatória.

\subsection{SISTEMA COM GERAÇÃO EÓLICA E RESISTOR DE FRENAGEM ENTRE MACHADINHO E ITÁ}

Foi adicionado um resistor série de $156 \Omega$ na linha de transmissão entre as usinas de Itá e Machadinho, dado que foi observado nos resultados da Fig. 4 que as duas máquinas sofrem maiores oscilações angulares. O comportamento do ângulo de carda dos geradores para esse caso pode ser visto na Fig. 6.

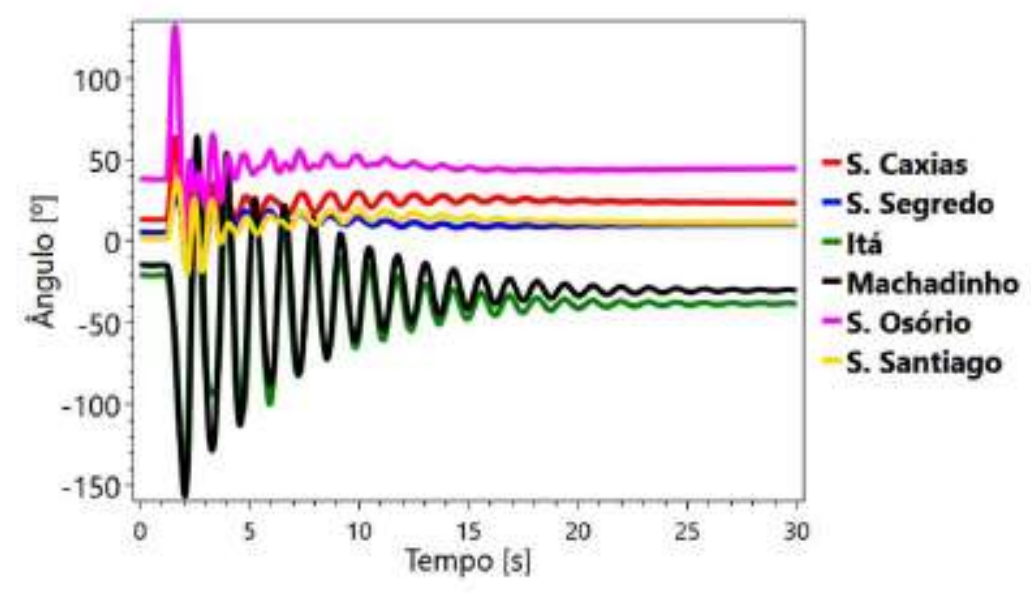

Fig. 6 Comportamento angular dos geradores com geração eólica e Resistor de Frenagem entre Itá e Machadinho para um curto-circuito trifásico franco na barra 1060. 
Apesar das oscilações permanecerem por aproximadamente 29 segundos nas máquinas de Itá e Machadinho, o sistema é estável. Assim, é notável que a localização e o valor adotado para o método de amortecimento utilizado são determinantes na resposta angular do sistema.

\subsection{SISTEMA COM GERAÇÃO EÓLICA E RESISTOR DE FRENAGEM ENTRE SALTO SEGREDO E SALTO}

\section{SANTIAGO - RESISTOR 2}

Foi adicionado o resistor referente aos dados elétricos da usina de Machadinho de $156 \Omega$ entre as usinas de Salto Segredo e Salto Santiago. A resposta para este caso pode ser vista na Fig. 7.

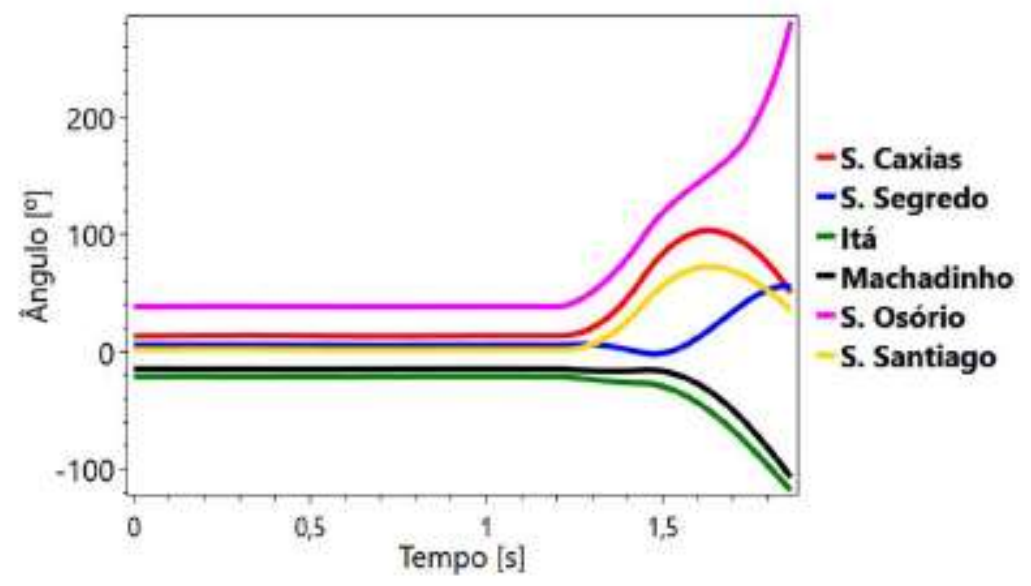

Fig. 7 Comportamento angular dos geradores com geração eólica e Resistor de Frenagem 2 entre S. Segredo e S. Santiago para um curto-circuito trifásico franco na barra 1060.

Observa-se que mesmo para um valor resistivo maior o sistema ainda apresenta um comportamento instável.

\subsection{ANÁLISE DE ESTABILIDADE ANGULAR COM CURTO-CIRCUITO EM DIFERENTES BARRAS DO}

\section{SISTEMA}

As análises realizadas nas subseções 6.1 a 6.5 mostram que a entrada do complexo parque eólico no sistema equivalente sul pode levar a perda da estabilidade angular transitória. A adoção do resistor de frenagem surtiu efeito apenas para a alocação entre a linha de transmissão que interliga as usinas de Machadinho e Itá, o que mostra que a utilização dessa técnica deve ser cuidadosamente analisada. Sendo assim, nesse item serão apresentados os resultados de diversas simulações de falta e a análise da estabilidade eletromecânica, conforme mostrado na Tabela 3. 
Tabela 3. Quantidade de usinas que apresentaram instabilidade angular sem e com ação do resistor de frenagem.

\begin{tabular}{|c|c|c|c|c|c|}
\hline \multirow{2}{*}{ Caso } & \multicolumn{2}{|c|}{ Barra } & \multirow{2}{*}{$\begin{array}{l}\text { D.F. } \\
{[\mathrm{ms}]}\end{array}$} & \multirow{2}{*}{ S.R.F. } & \multirow{2}{*}{ C.R.F. } \\
\hline & $\mathrm{DE}$ & PARA & & & \\
\hline 01 & 800 & 824 & 240 & 6 & 6 \\
\hline 02 & 808 & 897 & 240 & 1 & 1 \\
\hline 03 & 925 & 1060 & 240 & 1 & 1 \\
\hline 04 & 810 & 856 & 240 & 1 & 1 \\
\hline 05 & 919 & 1047 & 240 & 1 & 1 \\
\hline 06 & 915 & 1030 & 240 & 1 & 1 \\
\hline 07 & 904 & 995 & 240 & 1 & 1 \\
\hline 08 & 3011 & 1047 & 240 & 1 & 1 \\
\hline 09 & 898 & 839 & 110 & 1 & 0 \\
\hline 10 & 934 & 933 & 290 & 1 & 0 \\
\hline 11 & 955 & 933 & 240 & 0 & 0 \\
\hline 12 & 2458 & 839 & 180 & 1 & 0 \\
\hline 13 & 856 & 933 & 270 & 6 & 0 \\
\hline 14 & 1030 & 955 & 240 & 0 & 0 \\
\hline 15 & 1047 & 898 & 73 & 1 & 0 \\
\hline 16 & 959 & 895 & 290 & 0 & 0 \\
\hline 17 & 824 & 933 & 240 & 0 & 0 \\
\hline 18 & 897 & 1060 & 100 & 2 & 2 \\
\hline \multicolumn{4}{|c|}{$\begin{array}{l}\text { Total de Máquinas } \\
\text { Instáveis }\end{array}$} & 25 & 15 \\
\hline
\end{tabular}

Na Tabela 3, a numeração da coluna intitulada como Barra DE indica o ponto de ocorrência do curtocircuito para cada caso simulado; Barra DE - PARA indica a linha de transmissão entre os barramentos que será removida para eliminação do defeito; D.F. indica a duração do defeito; S.R.F. indica o número de usinas que perderam a estabilidade para o caso simulado sem o resistor de frenagem; C.R.F. indica o número de usinas que perderam a estabilidade para o caso simulado com o resistor de frenagem de $156 \Omega$ fixado na linha de transmissão que interliga as usinas de Machadinho e Itá. Todos os curtoscircuitos são trifásicos, sendo que a duração da falta para algumas das condições é modificada a fim de aproximar ao CCT do caso correspondente. Assim, as análises consideram pontos críticos ao sistema e pontos onde há opções para realocação do fluxo de potência, sendo estes menos críticos, uma vez que o sistema pode manter conexões importantes entre centros geradores e de carga por outras linhas de transmissão. Os grandes centros de carga também são alvos desta investigação. 
No Caso 01 há a perda da usina de referência do sistema, acarretando a instabilidade das demais usinas. Na ocorrência de um curto-circuito em uma barra PV (Casos 02 a 08), observar-se a perda da estabilidade da própria máquina geradora, uma vez que esta será desconectada do sistema elétrico. No Caso 08, a falta na barra 3011 é referente a planta eólica, e como consequência ocorre a perda da usina hidrelétrica mais próxima, sendo essa a de Salto Osório.

A linha de transmissão entre as barras 856 e 933 (Caso 13) é um importante ponto de fluxo de potência do sistema, e a perda desta linha levou a instabilidade de todas as usinas hidrelétricas geradoras para o caso sem o resistor de freio.

Posteriormente, com a presença do resistor de frenagem, observa-se a manutenção da estabilidade angular para todas as máquinas do sistema.

A linha de transmissão que conecta as barras 897 e 1060 (Caso 18) é um local que leva a estabilidade do sistema e, mesmo com a ação do resistor de freio, ocorreu à instabilidade de duas máquinas. Para os demais pontos não foi observado instabilidade em ambas as condições, isso ocorre significativamente por dois motivos. O primeiro é devido a outras opções de linha de transmissão por onde há a transferência de fluxo de potência. O outro é que o local é próximo de grandes centros de carga, assim, ao desconectar a barra do sistema ocorre um alívio de carga, que é uma estratégia que pode ser utilizada para manter a estabilidade angular do sistema.

\section{CONCLUSÕES}

O presente trabalho buscou analisar a influência a penetração de usinas eólicas de grande porte em um sistema elétrico de potência representativo da região sul do SIN. Adicionalmente, verificou-se a viabilidade do uso de resistor série de frenagem como alternativa para diminuir as oscilações eletromecânicas após a ocorrência de uma perturbação no sistema.

Observou-se que a inserção de parques eólicos em um sistema originalmente estável ocasionou a instabilidade angular de duas usinas geradoras. Para contornar o problema, foi adicionado um resistor de frenagem com o intuito de diminuir as oscilações eletromecânicas. Com isso, verificou-se a influência que o ponto de conexão entre as usinas de Machadinho e Itá possui no sistema, o que garantiu a estabilidade. Para verificar a eficiência da ação controladora na linha de transmissão entre Machadinho e Itá foram causados curtos-circuitos em outras barras do sistema. Dessa forma, observou-se a eficiência do método para casos em que a duração do curto-circuito é próxima ao tempo crítico de eliminação do defeito. 
Observou-se que a utilização do resistor de frenagem reduziu de 25 para 15 usinas desligadas durante os curtos-circuitos aplicados no sistema, apresentando ser uma boa alternativa para auxiliar na estabilidade do sistema considerando a penetração de usinas eólicas. Por fim, outros trabalhos podem ser realizados buscando verificar técnicas mais robustas para o controle da inserção e retirada do resistor de frenagem e a localização ótima desse equipamento no sistema. 


\section{REFERÊNCIAS}

Alves, W. F. (2007). Proposição de sistemas-teste para análise computacional de sistemas de potência. Dissertação de mestrado. Universidade Federal Fluminense. Niteroi,. RJ.. 2007.

CEPEL (2006). - Centro de Pesquisas de Energia Elétrica. Procedimentos para preparação de casos de simulação com máquina de indução duplamente alimentada nos programas ANAREDE e ANATEM. vV. 10, novembro de 2006.

Edrah, M., Lo, K. L. and Anaya-Lara, O. (2015). Impacts of high penetration of DFIG wind turbines on rotor angle stability of power systems. IEEE Transactions Onon Sustainable Energy, volume 6, p. 759766.. 2015.

Kundur, P. (1994). Power system stability and control. McGraw-Hill, Inc., 1994.

Naimi, D. and Bouktir, T. (2008). Impact of wind power on the angular stability of a power system. Leonardo Electronic Journal of Practices and Technologies. p. 83- 94., 2008.

Okedu, K.E. (2020). Determination of the Most Effective Switching Signal and Position of Breaking Resistor in DFIG Wind Turbine under Transient Conditions. Electr Eng, p. 471-480.

ONS (2009) -. Operador Nacional do Sistema Elétrico. Relação dos sistemas e modelos computacionais. Submódulo 18.2. Rio de Janeiro, Brasil, agosto de 2009.

ONSONS (2014). - Operador Nacional do Sistema Elétrico. Boletim mensal de geração eólica Abril/2014. Rio de Janeiro, Brasil, Abril de 2014.

ONS (2018). - Operador Nacional do Sistema Elétrico. Plano de ampliações e reforços nas instalações de transmissão do SIN. PAR Executivo 2019-2023. Rio de Janeiro, Brasil, novembro de 2018.

ONS (2019). - Operador Nacional do Sistema Elétrico. Boletim mensal de geração eólica Abril/2019. Rio de Janeiro, Brasil, Abril de 2019.

Qiao, W. and Harley, R. G. (2008). Effect of grid-connected DFIG wind turbines on power system transient stability.

IEEE Power and Energy Society General Meeting - Conversion and Delivery of Electrical Energy in the $21^{\text {st }}$ Century. 2008.

Robak S. And and Gryszpanowicz, K. (2018). Comprehensive Dimensioning of series braking resistor for transient stability improvement. Electric Power Systems Research. Elsevier, Poland, 2018p. 59-66.

Robak, S. et al. (2019). Transient Stability Enhancement by Series Braking Resistor Control using Local Measurements. Electric Power and Energy Systems. Elsevier, p. 272-281.

Robak, S. et al. (2019). Transient Stability Enhancement by Series Braking Resistor Control using Local Measurements. Electric Power and Energy Systems. Elsevier, p. 272-281.

Vittal, E., O' malley, M. And Keane, A. (2012). Rotor angle stability with high penetrations of wind generation. IEEE Power and Energy Society General Meeting. 2012. 


\section{Capítulo 2}

\section{doi $10.37423 / 211104996$}

\section{ATTITUDE ESTIMATION USING A TWO-STEP UNSCENTED APPROACH WITH GYRO BIAS ESTIMATION AND ACCELERATION CORRECTION}

Guilherme Silva Terra

Leonardo A. B. Torres

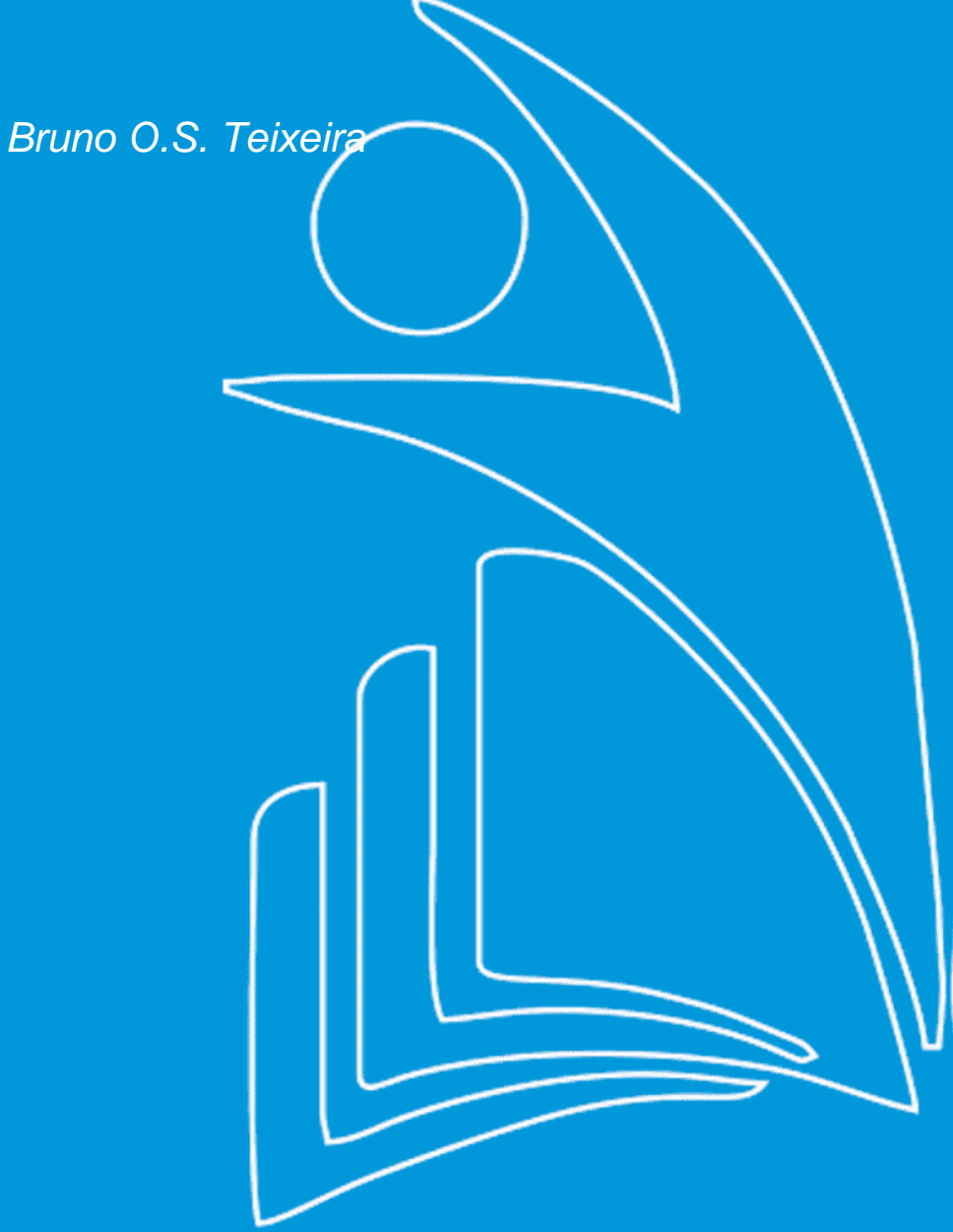

Universidade Federal de Minas Gerais

Universidade Federal de Minas Gerais

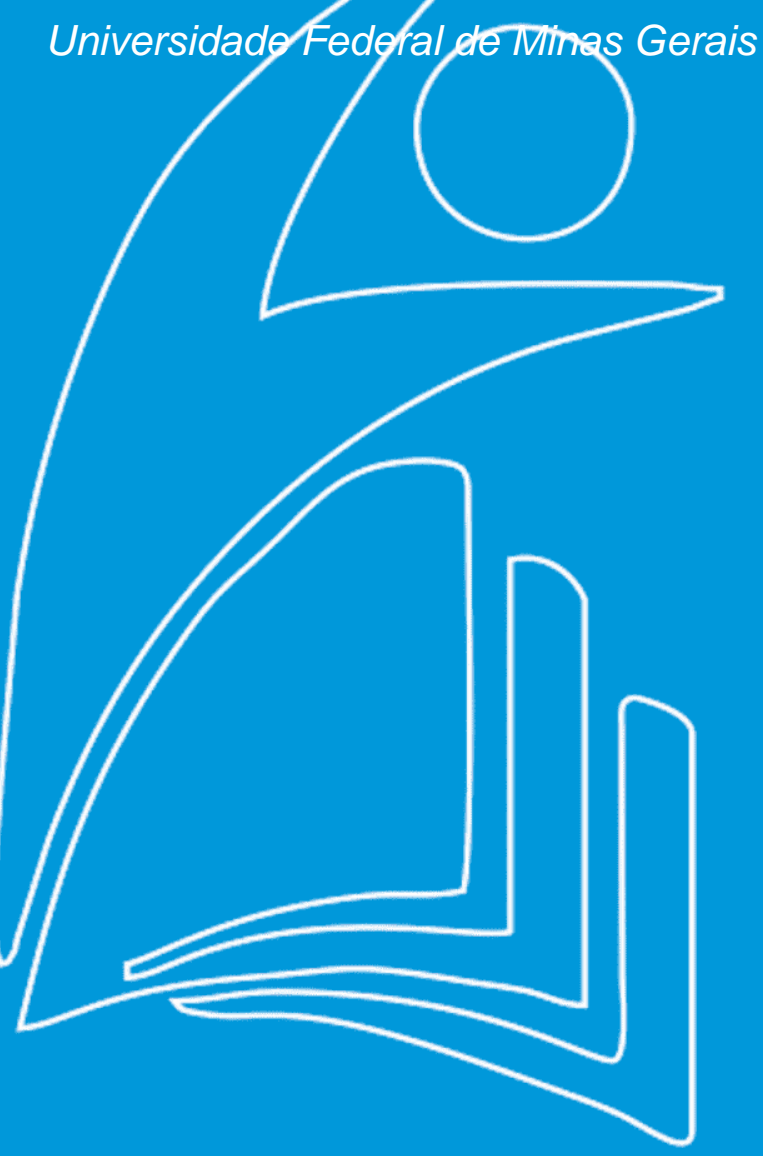


Abstract: In the last years, the interest for research on unmanned aerial vehicles (UAVs) has grown up due to the vast_eld of application of these aircrafts. For such aircrafts, it is crucial to have an automatic pilot system, which also demands the knowledge of the location and spatial orientation. Thus, this work implements and tests in simulation environment a sensor fusion algorithm that is able to estimate the attitude of UAVs. The algorithm implemented is based on the unscented Kalman _Iter (UKF). It corrects the measurements of accelerometers and estimates the gyro bias. It is assessed in simulation environment by means of simulated ights, considering the modeling of the uncertainties of the sensors. Also a comparison is made with an EKF-based algorithm to verify the bene_ts and drawbacks of the unscented approach.

Keywords: UAV, recursive estimation, UKF. 


\section{INTRODUCTION}

In the development of UAVs, a basic premise is to know the position and attitude of the vehicle. This information can be obtained from an inertial navigation system, which, generally, implements sensor fusion algorithms that process the measure- ments from sensor embedded in the vehicle. For UAV attitude estimation, the algorithm generally combines measurements from accelerometers, gy- ros, magnetometers and eventually GPS receivers. However, these sensors have some intrinsic error sources, such as cross sensibility, misalignment, noise and bias, that can compromise the attitude estimate. Therefore, it is important to consider these error sources in the estimation algorithm.

In this context, many works have considered the use of sensor fusion algorithms for attitude estimation, in particular EKF-based quaternion attitude estimation algorithms (Bo and Borges, 2007) (Hemerly and Schad, 2004) (Ma et al., 2012). In this work, we use the unscented ap- proach to improve the attitude estimation.

A constrained UKF-based (Tang et al., 2012) algorithm is implemented and analyzed in simu- lation environment, which considers sensor mo- dels to treat the measurement errors. Three flight simulations are tested: a straight leveled flight, a flight with longitudinal accelerated movement and another one with typical maneuvers such as climbs, turns and descents.

The implementation proposed in this paper is based on the algorithm described in (Lima, 2013) called mEKF7s, which uses the EKF. This al-gorithm combines vehicle acceleration corrections and gyro bias estimation in a pre-processing step using analytical linearization in the propagation of the sensor measurements. Unlike other pa-pers (Shin, 2004)(Bae and Kim, 2010)(Tang et al., 2012), the main contribution of this work is to ap- ply the unscented transform at this pre-processing of measurements. Both approaches are analyzed in simulation environment to verify the benefits and costs of the unscented approach.

The paper is organized as follows. In the next section, the problem statement is presented. In Section 3, the algorithms for nonlinear Kalman fil- ters are revised while, in Section 4, the algorithm for attitude estimation is presented. In Section 5, this algorithm is tested in simulation environ- ment. Finally, Section 6 contains the concluding remarks. This paper is based on the results pre- sented in (Terra, 2013). 
Consider the stochastic discrete-time nonlinear dynamic system

$$
x_{k}=f\left(x_{k-1}, u_{k-1}, w_{k-1}\right),
$$

Where $f: \Re^{n} \times \Re^{p} \times \Re^{q} \rightarrow \Re^{n}$ with measurement map

$$
y_{k}=h\left(x_{k}\right)+v_{k},
$$

where $h: \Re^{n} \rightarrow \Re^{m}$ and k denotes discrete time.

The process noise $w_{k} \in \Re^{q}$ and the measurement noise $v_{k} \in \Re^{m}$ are considered to have zero mean and known covariance matrices $Q_{k}$ and $R_{k}$, respectively.

They are also assumed to be mutually independent. Assume that, for all $k \geq 0$, the input $u_{k} \in \Re^{p}$ is known from sensors and, for all $k \geq 1$, the output $y_{k} \in \Re^{m}$ is also measured.

The state-estimation problem is to obtain an estimate for the state vector $x_{k}$ that maximizes a profit function given by

$$
J\left(x_{k}\right) \triangleq \rho\left(x_{k} \mid\left(y_{1}, y_{2}, \ldots, y_{k}\right)\right)
$$

The profit function $J\left(x_{k}\right)$ represents the value of conditional probability density function of $x_{k}$ given the past and present measured data $y_{1}, y_{2}, \ldots, y_{k}$ However, for nonlinear systems, the conditional probability density function could not be completely characterized by its mean $\hat{x}_{k \mid k}$ and covariance matrix $P_{k \mid k}^{x x}$. Thus we use approximations based on the classical Kalman filter (KF) for linear systems to obtain suboptimal solution for nonlinear systems, specifically the EKF and UKF.

In this paper, the state vector $x_{k}$ represents the aircraft attitude, in unit quaternion, and gyro bias. The input vector $u_{k}$ is given by the gyro measurements and the output vector $y_{k}$ is given by the quaternion vector inferred from sensors measurements (accelerometers, gyros, magnetometer and GPS receiver) using the unscented transform during the pre-processing step. 


\section{NONLINEAR KALMAN FILTERING}

\subsection{EXTENDED KALMAN FILTER (EKF)}

For nonlinear systems, an approximate solution to the state-estimation problem is to linearize analytically the nonlinear model around the most current state estimate and apply the original KF equations (Simon, 2006). This algorithm is known as the extended Kalman filter (EKF).

In the first-order EKF, the nonlinear functions are approximated by their respective firstorder Taylor series expansions. The linearization of the model (1)-(2) is compounded by

$$
\begin{aligned}
\bar{F}_{x, k-1} & \left.\triangleq \frac{\partial f}{\partial x_{k-1}}\right|_{\hat{x}_{k-1 \mid k-1}, u_{k-1}, 0_{q \times 1}}, \\
\bar{F}_{w, k-1} & \left.\triangleq \frac{\partial f}{\partial w_{k-1}}\right|_{\hat{x}_{k-1 \mid k-1}, u_{k-1}, 0_{q \times 1}}, \\
\bar{H}_{x, k} & \left.\triangleq \frac{\partial h}{\partial x_{k}}\right|_{\hat{x}_{k \mid k-1}} .
\end{aligned}
$$

The EKF propagates the previous estimates through the nonlinear functions defined by (1)-(2).

The propagation of the covariance matrices uses the Jacobian matrices defined in (4)-(6). Thus the forecast step of the EKF has the following equations:

$$
\begin{aligned}
\hat{x}_{k \mid k-1}= & f\left(\hat{x}_{k-1 \mid k-1}, u_{k-1}, 0_{q \times 1}\right), \\
P_{k \mid k-1}^{x x}= & \bar{F}_{x, k-1} P_{k-1 \mid k-1}^{x x} \bar{F}_{x, k-1}^{T} \\
& +\bar{F}_{w, k-1} Q_{k-1} \bar{F}_{w, k-1}^{T}, \\
\hat{y}_{k \mid k-1}= & h\left(\hat{x}_{k \mid k-1}\right), \\
P_{k \mid k-1}^{y y}= & \bar{H}_{x, k} P_{k \mid k-1}^{x x} \bar{H}_{x, k}^{T}+R_{k}, \\
P_{k \mid k-1}^{x y}= & P_{k \mid k-1}^{x x} \bar{H}_{x, k}^{T},
\end{aligned}
$$

where $P_{k \mid k-1}^{x x}$ is the forecast error covariance, $P_{k \mid k-1}^{x y}$ is the innovation covariance, $P_{k \mid k-1}^{x y}$ the cross covariance and $P_{k \mid k}^{x x}$ is the data-assimilation error covariance.

With the arrival of new measurements $y_{k}$, the EKF corrects the estimate propagated in the dataassimilation step, which is given by 


$$
\begin{aligned}
K_{k} & =P_{k \mid k-1}^{x y}\left(P_{k \mid k-1}^{y y}\right)^{-1}, \\
\hat{x}_{k \mid k} & =\hat{x}_{k \mid k-1}+K_{k}\left(y_{k}-\hat{y}_{k \mid k-1}\right), \\
P_{k \mid k}^{x x} & =P_{k \mid k-1}^{x x}-K_{k} P_{k \mid k-1}^{y y} K_{k}^{T},
\end{aligned}
$$

Where $K_{k} \in \Re^{n \times m}$ is the Kalman gain matrix.

\subsection{SQUARE-ROOT EQUALITY-CONSTRAINED UNSCENTED KALMAN FILTER (SR-UKF)}

There is another approximate solution that does not require analytical or numerical linearization and stands out for being more eficient in the propagation of states of nonlinear systems. This procedure is known as the unscented Kalman filter (UKF) and it is based on statistical linearization.

The UKF is based on the unscented transform (UT)(Julier, 2002), which propagates a random vector $x \in \Re^{n}$ through a nonlinear function h yielding $y=h(x)$..

A special case of UKF is called cubature Kalman_Iter (CKF). The CKF assumes that the prior estimate $x$ has a Gaussian probability density function (Simon and Arasaratnam, 2009). In this work, we use the cubature approach. Furthermore, in order to ensure numeric stability of the algorithm, we use the SRUKF (square root) version. That adaptation propagates the Cholesky matrix itself instead of the covariance matrix (Merwe and Wan, 2001) and it is used for the implementation in hardware.

Basically, to perform the UT with the squareroot and cubature approaches in the nonlinear propagation $y=h(x)$ with $h: \Re^{n} \rightarrow \Re^{m}$, we use the following equations:

$$
\begin{aligned}
\mathcal{X} & =\hat{x}\left(1_{1 \times 2 n}\right)+\sqrt{n}\left[\begin{array}{ll}
S^{x x} & -S^{x x}
\end{array}\right], \\
\mathcal{Y}_{i} & =h\left(\mathcal{X}_{i}\right), \\
\hat{y} & =\sum_{i=1}^{2 n} \omega \mathcal{Y}_{i}, \\
\Pi_{\mathcal{Y}} & =\sqrt{\omega}\left(\mathcal{Y}-\hat{y}\left(1_{1 \times 2 n}\right)\right), \\
S^{y y} & =\left(Q R\left\{\left[\Pi_{\mathcal{Y}}\right]^{T}\right\}\right)^{T},
\end{aligned}
$$

where $\hat{x}, \hat{y}, S^{x x}$ and $S^{y y}$ are, respectively, the averages and the Cholesky matrices for the random vectors of input $x \in \Re^{n}$ and output $y \in \Re^{m}$. Furthermore, $\omega=\frac{1}{2 n}$ is the weight factor, $1_{1 \times 2 n}$ 
is a row vector of ones and $Q R\{\cdot\}$ denotes the QR decomposition on which just the upper triangular matrix is returned.

The vector propagated by the unscented transform in the forecast step is called augmented state vector and includes the process noise, wk.

The augmented state vector is defined by

$$
x_{k-1 \mid k-1}^{(a)} \triangleq\left[\begin{array}{ll}
x_{k-1 \mid k-1}^{T} & w_{k-1}^{T}
\end{array}\right]^{T} \text {, }
$$

with dimension $n_{a}=n+q$, so that the mean and the Cholesky decomposition of covariance matrix are, respectively

$$
\begin{aligned}
& \hat{x}_{k-1 \mid k-1}^{(a)}=\left[\begin{array}{ll}
\hat{x}_{k-1 \mid k-1}^{T} & 0_{q \times 1}^{T}
\end{array}\right]^{T}, \\
& S_{k-1 \mid k-1}^{x x(a)}=\left[\begin{array}{cc}
S_{k-1 \mid k-1}^{x x} & 0 \\
0 & S_{k-1}^{Q}
\end{array}\right],
\end{aligned}
$$

where $S_{k-1}^{Q}$ is the Cholesky decomposition of $Q_{k-1}$..

Applying the UT to the augmented state vector, $2 n_{a}$ sigma-points are generated. Each one of these points can be separated into $n$ elements for the states $\mathcal{X}_{i}^{(x)}$ and q elements for the process noise $\mathcal{X}_{i}^{(w)}$ as

$$
\left[\begin{array}{ll}
\mathcal{X}_{i}^{(x)^{T}} & \mathcal{X}_{i}^{(w)^{T}}
\end{array}\right]^{T} \triangleq \mathcal{X}_{i}^{(a)}
$$

Thus the forecast step of the SR-UKF has the following equations: 


$$
\begin{aligned}
\mathcal{X}_{k-1 \mid k-1}^{(a)}= & \hat{x}_{k-1 \mid k-1}^{(a)}\left(1_{1 \times 2 n_{a}}\right) \\
& +\sqrt{n_{a}}\left[S_{k-1 \mid k-1}^{x x(a)}-S_{k-1 \mid k-1}^{x x(a)}\right], \\
\mathcal{X}_{i, k \mid k-1}^{(x)}= & f\left(\mathcal{X}_{i, k-1 \mid k-1}^{(x)}, u_{k-1}, \mathcal{X}_{i, k-1 \mid k-1}^{(w)}\right) \\
\hat{x}_{k \mid k-1}= & \sum_{i=1}^{2 n_{a}} \omega \mathcal{X}_{i, k \mid k-1}^{(x)}, \\
\Pi_{\mathcal{X}_{k \mid k-1}=} & \sqrt{\omega}\left(\mathcal{X}_{k \mid k-1}^{(x)}-\hat{x}_{k \mid k-1}\left(1_{1 \times 2 n_{a}}\right)\right) \\
S_{k \mid k-1}^{x x}= & \left(Q R\left\{\left[\Pi_{\mathcal{X}_{k \mid k-1}}\right]^{T}\right\}\right)^{T}, \\
\mathcal{X}_{k \mid k-1}= & \hat{x}_{k \mid k-1}\left(1_{1 \times 2 n}\right) \\
& +\sqrt{n}\left[S_{k \mid k-1}^{x x}-S_{k \mid k-1}^{x x}\right], \\
\mathcal{Y}_{i, k \mid k-1}= & h\left(\mathcal{X}_{i, k \mid k-1}\right), \\
\hat{y}_{k \mid k-1}= & \sum_{i=1}^{2 n} \omega \mathcal{Y}_{i, k \mid k-1}, \\
\Pi_{\mathcal{Y}_{k \mid k-1}=} & \sqrt{\omega}\left(\mathcal{Y}_{k \mid k-1}-\hat{y}_{k \mid k-1}\left(1_{1 \times 2 n}\right)\right) \\
S_{k \mid k-1}^{y y}= & \left(Q R\left\{\left[\Pi_{\mathcal{Y}_{k \mid k-1}} S_{k}^{R}\right]^{T}\right\}\right)^{T} . \\
P_{k \mid k-1}^{x y}= & \Pi_{\mathcal{X}_{k \mid k-1}}\left(\Pi_{\mathcal{Y}_{k \mid k-1}}\right)^{T}, \\
= & (32) \\
= &
\end{aligned}
$$

where $S_{k}^{R}$ is the Cholesky decomposition of $R_{k}$.

In the data-assimilation step, the Kalman gain is calculated as

$$
K_{k}=\left(P_{k \mid k-1}^{x y} /\left(S_{k \mid k-1}^{y y} T\right)\right) / S_{k \mid k-1}^{y y} .
$$

Finally, we have

$$
\begin{gathered}
\hat{x}_{k \mid k}^{(u)}=\hat{x}_{k \mid k-1}+K_{k}\left(y_{k}-\hat{y}_{k \mid k-1}\right) \\
S_{k \mid k}^{x x(u)}=\left(Q R \left\{\left[\left(\Pi_{\mathcal{X}_{k \mid k-1}}-K_{k} \Pi_{y_{k \mid k-1}}\right)\right.\right.\right. \\
\left.\left.\left.K_{k} S_{k}^{R}\right]^{T}\right\}\right)^{T}
\end{gathered}
$$

Now, suppose that the state vector must satisfy the nonlinear constraint

$$
c\left(x_{k \mid k}\right)=0_{n_{c} \times 1},
$$


where $c: \Re^{n} \rightarrow \Re^{n_{c}}$ is the nonlinear constraint function. In order to ensure that the estimates satisfy this constraint, we consider the projection function $p: \Re^{n} \rightarrow \Re^{n}$.

$$
c\left(p\left(x_{k \mid k}^{(u)}\right)\right)=0_{n_{c} \times 1} .
$$

Therefore, the goal of the projection function is to transform the unconstrained state into the constrained state (Tang et al., 2012) (Teixeira et al., 2009), i.e.,

$$
x_{k \mid k}=p\left(x_{k \mid k}^{(u)}\right) .
$$

In the equality-constrained SR-UKF algorithm we consider a third step, called projection step. It is de_ned by the following equations:

$$
\begin{aligned}
& \mathcal{X}_{k \mid k}^{(u)}=\hat{x}_{k \mid k}^{(u)}\left(1_{1 \times 2 n}\right)+\sqrt{n}\left[S_{k \mid k}^{x x(u)}-S_{k \mid k}^{x x(u)}\right](40) \\
& \mathcal{X}_{i, k \mid k}^{(p)}=p\left(\mathcal{X}_{i, k \mid k}^{(u)}\right) \\
& \hat{x}_{k \mid k}^{(p)}=\sum_{i=1}^{2 n} \omega \mathcal{X}_{i, k \mid k}^{(p)} \\
& \Pi_{\mathcal{X}_{k \mid k}^{(p)}}=\sqrt{\omega}\left(\mathcal{X}_{k \mid k}^{(p)}-\hat{x}_{k \mid k}^{(p)}\left(1_{1 \times 2 n}\right)\right) \\
& \hat{x}_{k \mid k}=p\left(\hat{x}_{k \mid k}^{(p)}\right) \\
& S_{k \mid k}^{x x}=\left(Q R\left\{\left[\Pi_{\mathcal{X}_{k \mid k}^{(p)}}\left(\hat{x}_{k \mid k}-\hat{x}_{k \mid k}^{(p)}\right)\right]^{T}\right\}\right)^{T}
\end{aligned}
$$

In (40)-(43), the projection is applied to the unconstrained estimate across the entire distribution, while in (44)-(45) the mean is translated so that it lies on the constraint surface.

4 The attitude estimator algorithm The main characteristics of the EKF-based attitude estimator algorithm of (Lima, 2013) are the acceleration correction and the gyro bias estimation.

This algorithm is based on two others: the first one considers the bias estimation of gyros (Jang and Liccardo, 2006) and the second one is characterized by the acceleration correction (Ma et al., 2012). All of them use the unit quaternion to represent the attitude.

In this paper we use another algorithm keeping these characteristics, but considering the unscented approach. The attitude estimator discussed in this work is based on the SR-UKF. A diagram that illustrates this algorithm is shown in Figure 1. This algorithm uses the information of accelerometers, gyros, magnetometers and GPS receiver. 
These measurements undergo a pre-processing step, in which an attitude estimate is inferred. This open loop estimate is later used as indirect measurements in the data-assimilation step of the SR-UKF (second step).

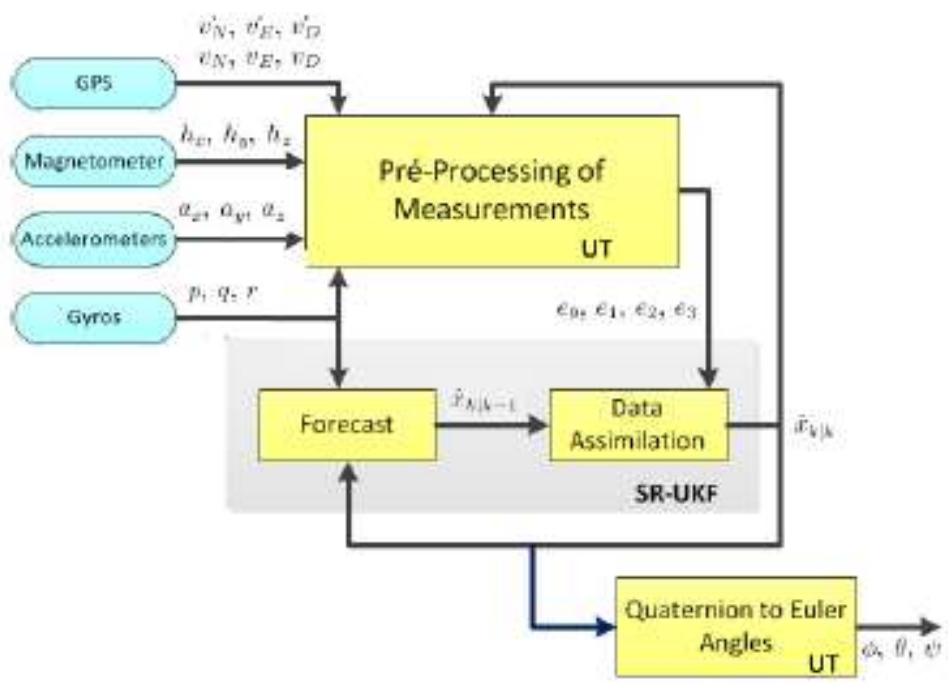

Figure 1: Diagram of the attitude estimator

\subsection{DYNAMIC MODELING}

The attitude estimation algorithm needs a dynamic model for the SR-UKF to perform its forecast step. The model can be characterized by the equations of evolution (1) and observation (2) of the states. Where, $\mathrm{x}$ is compounded by attitude vector, represented by the quaternion

$$
e=\left[\begin{array}{llll}
e_{0} & e_{1} & e_{2} & e_{3}
\end{array}\right]^{T},
$$

and also estimates of the gyros bias, represented by

$$
\beta=\left[\begin{array}{lll}
b_{p} & b_{q} & b_{r}
\end{array}\right]^{T} .
$$

Therefore, the model used by the algorithm is a 7-state vector, represented by

$$
x=\left[\begin{array}{lllllll}
e_{0} & e_{1} & e_{2} & e_{3} & b_{p} & b_{q} & b_{r}
\end{array}\right]^{T} .
$$

Because of that, this algorithm is called SRUKF7s. The input vector of the model is composed by the gyro measurements

$$
u=\left[\begin{array}{lll}
p & q & r
\end{array}\right]^{T} .
$$


The model used by the algorithm considers the attitude representation by a unit quaternion, which is subject to the equality constraint

$$
e_{0}^{2}+e_{1}^{2}+e_{2}^{2}+e_{3}^{2}=1
$$

In this case, the unconstrained state estimated by equations (36) must be projected onto the constrained surface by using (40)-(45), with

$$
p\left(x_{k \mid k}\right)=\left[\begin{array}{llll}
\frac{e_{k \mid k}}{\left\|e_{k \mid k}\right\|} & b_{p} & b_{q} & b_{r}
\end{array}\right]^{T},
$$

where $e_{k \mid k} \in \Re^{4 \times 1}$ is the quaternion vector.

The relation between the unit quaternion and the Euler angles $(\phi, \theta \mathrm{e} \psi)$, in the rotation sequence used in aeronautics $(Z \rightarrow Y \rightarrow X)$ is de- fined in (Diebel, 2006). Unlike the Euler angles, the unit quaternion has no singularities and there exists a discrete time equation that is exact for the attitude propagation (Teixeira et al., 2009). However, the attitude estimated can be better analyzed and understood by the Euler angles. So, the quaternion estimated is converted to the Euler angles in the end of the algorithm using the unscented transform.

The model used in both EKF and SR-UKF considers the process noise as an input of the state evolution function. In this case, the process noise is associated to the gyro measurements, $w^{(g)}$, and to the bias estimation, $w^{(\beta)}$. They are signals assumedly Gaussian, with zero mean and the deviations represented by $\sigma_{p}, \sigma_{q}$ and $\sigma_{r}$ the gyro measurements, and $\sigma_{b_{p}}, \sigma_{b_{q}}$ and $\sigma_{b}$ for the bias estimation. Therefore, the state evolution function $f(x, u, w)$, of the equation (1) is de_ned by

$$
\left[\begin{array}{c}
e_{k} \\
\beta_{k}
\end{array}\right]=\left[\begin{array}{ll}
A_{k-1} & 0_{4 \times 3} \\
0_{3 \times 4} & I_{3 \times 3}
\end{array}\right]\left[\begin{array}{c}
e_{k-1} \\
\beta_{k-1}
\end{array}\right]+\left[\begin{array}{c}
0_{4 \times 1} \\
w_{k-1}^{(\beta)}
\end{array}\right],
$$

where $e_{k-1} \in \Re^{4 \times 1}$ is the quaternion vector and $A_{k-1}$ is the matrix given by

$$
A_{k-1}=\cos \left(\mathrm{s}_{\mathrm{k}-1}\right) \mathrm{I}_{4 \times 4}-0,5 \mathrm{~T}_{\mathrm{s}} \frac{\sin \left(\mathrm{s}_{\mathrm{k}-1}\right)}{\mathrm{s}_{\mathrm{k}-1}} \Omega_{\mathrm{k}-1}^{*}
$$

where $s_{k-1}$ is the norm of the angular velocity, given by 


$$
s_{k-1}=0,5 T_{s} \sqrt{p^{2}+q^{2}+r^{2}},
$$

in which $T_{s}$ is the sampling period. Finally, the matrix $\Omega_{k-1}^{*}$ is given by

$$
\Omega_{k-1}^{*}=\left[\begin{array}{cccc}
0 & p^{*} & q^{*} & r^{*} \\
-p^{*} & 0 & -r^{*} & q^{*} \\
-q^{*} & r^{*} & 0 & -p^{*} \\
-r^{*} & -q^{*} & p^{*} & 0
\end{array}\right],
$$

where $p^{*}, q^{*}$ e $r^{*}$ are the components of the angular velocity, $u_{-} k$ ? 1 , after inserting the process noise and correcting with the estimated gyro bias, i.e.,

$$
u_{k-1}^{*}=u_{k-1}+w_{k-1}^{(g)}-\beta_{k-1} .
$$

The state observer equation, $h(x)$, of the equation (2) returns the own attitude in quaternion representation, i.e,

$$
y_{k}=\left[\begin{array}{llll}
e_{0, k}^{m} & e_{1, k}^{m} & e_{2, k}^{m} & e_{3, k}^{m}
\end{array}\right]^{T} .
$$

Despite the quaternion not to be measured directly by the sensors, it is calculated from the sensors by the pre-processing, as showed in Figure 1 and described in Section 4.2.

\subsection{PRE-PROCESSING OF MEASUREMENTS}

Before running the SR-UKF, the algorithm SRUKF7s performs a pre-processing of measurements.

The main goal of this pre-processing step is, from the sensor measurements, to estimate the quaternion vector (55). The sensor measurements present uncertainties associated, and because of that, they are here represented by Gaussian statistics, whose variances are showed in Table 1. Therefore, the pre-processing of measurements performs a propagation of the measurements through nonlinear functions and, to accomplish that, we use the unscented transform. A diagram that illustrate the calculations realized in this processing is showed in Figure 2. 


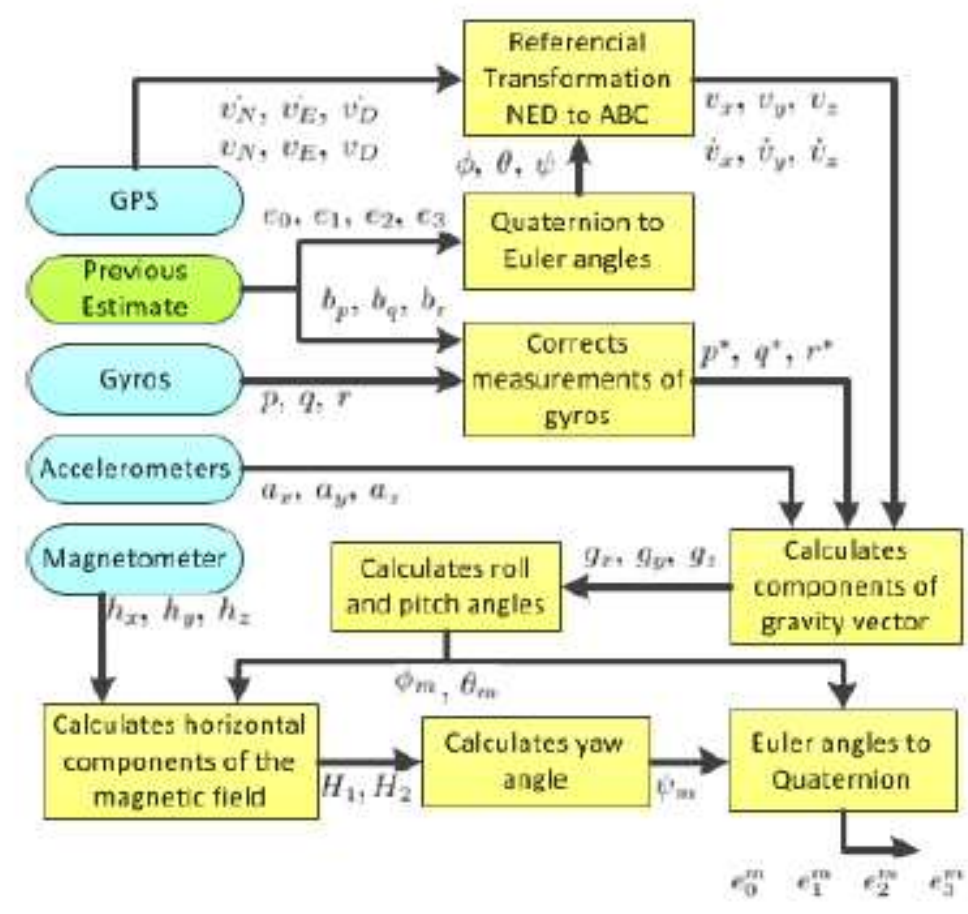

Figure 2: Diagram of the pre-processing step of the attitude estimator

Table 1: Variances used in algorithm

\begin{tabular}{|c|c|c|}
\hline Sensor & Variable & Variance \\
\hline Accelerometer & liner acceleration & $223,59 \times 10^{-9}\left[\mathrm{~m}^{2} / \mathrm{s}^{4}\right]$ \\
\hline Gyro & angular velocity & $4,1 \cdot 10^{-3}\left[\mathrm{rad}^{2} / \mathrm{s}^{2}\right]$ \\
\hline Gyro & bias & $2,02 \cdot 10^{-8}\left[\mathrm{rad}^{2} / \mathrm{s}^{2}\right]$ \\
\hline Magnetometer & magnetic field & $24,1 \cdot 10^{-3}\left[\mathrm{Ga}^{2}\right]$ \\
\hline GPS & velocity & $1,6 \cdot 10^{-3}\left[\mathrm{~m}^{2} / \mathrm{s}^{2}\right]$ \\
\hline GPS & acceleration & $3,2 \cdot 10^{-3}\left[\mathrm{~m}^{2} / \mathrm{s}^{4}\right]$ \\
\hline
\end{tabular}

One of the main characteristic of this preprocessing step is the compensation of the components of gravity acceleration read from accelerometers.

Those components are disturbed when the aircraft performs dynamic maneuvers. In this way, the measurements of the accelerometers $\left(a_{x}, a_{y}\right.$ and $\left.a_{z}\right)$ are compensated by the linear velocities $\left(v_{x}, v_{y}\right.$ and $\left.v_{z}\right)$ and accelerations $\left(\dot{v}_{x}, \dot{v}_{y}\right.$ and $\left.\dot{v}_{z}\right)$ and also by the angular velocities ( $\mathrm{p}, \mathrm{q}$ and $\mathrm{r}$ ) measured from the gyros, all those variables in the vehicle reference frame. Therefore, the components of the gravity acceleration in the aircraft reference frame are given by

$$
\begin{aligned}
& g_{x}=a_{x}-\left(\dot{v}_{x}+v_{z}\left(q-b_{q}\right)-v_{y}\left(r-b_{r}\right)\right) \\
& g_{y}=a_{y}-\left(\dot{v}_{y}+v_{x}\left(r-b_{r}\right)-v_{z}\left(p-b_{p}\right)\right) \\
& g_{z}=a_{z}-\left(\dot{v}_{z}+v_{y}\left(p-b_{p}\right)-v_{x}\left(q-b_{q}\right)\right) .
\end{aligned}
$$


The linear velocities and accelerations in the aircraft reference frame are calculated from the estimates of velocity $\left(v_{N}, v_{E}\right.$ and $\left.v_{D}\right)$ and acceleration $\left(\dot{v}_{N}, \dot{v}_{E}\right.$ and $\left.\dot{v}_{D}\right)$ in NED ${ }^{1}$ reference frame obtained from the GPS. It is done using the most current attitude estimate, as described in (Diebel, 2006).

The roll $(\phi)$ and pitch $(\theta)$ angles can be calculated from the components of the gravity acceleration computed in equations (56), as

$$
\begin{aligned}
& \phi_{m}=\tan ^{-1}\left(\frac{g_{y}}{g_{z}}\right) \\
& \theta_{m}=\tan ^{-1}\left(\frac{-g_{x} \cos \phi_{m}}{g_{z}}\right) .
\end{aligned}
$$

The yaw $(\psi)$ angle is calculated from the measurements of the magnetometers $\left(h_{x}, h_{y}\right.$ and $\left.h_{z}\right)$.

For that, it is done a decomposition of the magnetic field with the angles $\phi_{m}$ and $\theta_{m}$ calculated in equations (57). So,

$$
\begin{aligned}
H_{1}= & h_{x} \cos \theta_{m}+h_{y} \sin \phi_{\mathrm{m}} \sin \theta_{\mathrm{m}} \\
& +h_{z} \cos \phi_{m} \sin \theta_{\mathrm{m}}, \\
H_{2}= & h_{z} \sin \phi_{\mathrm{m}}-\mathrm{h}_{\mathrm{y}} \cos \phi_{\mathrm{m}} .
\end{aligned}
$$

Therefore, disconsidering the inclination angle of the Earth magnetic field, the yaw angle, $\psi_{m}$, is given by

$$
\psi_{m}=\tan ^{-1}\left(\frac{H_{2}}{H_{1}}\right)
$$

The Euler angles calculated in equations (57) and (59) are converted into the unit quaternion representation. Finally, the quaternion represents the measurement vector used in the dataassimilation step of SR-UKF. The square-root covariance matrix SR k, which characterizes the uncertainty of measurements in terms of SR-UKF, is calculated at each iteration from the propagated representations in this pre-processing according to the unscented transform. 


\section{SIMULATED RESULTS}

\subsection{MODELING SENSORS}

In the implementation of the sensor fusion algorithm, it is necessary to know models that represent the relations between the variables measured by the sensors. In this work, the algorithm uses measurements from accelerometers, gyros, magnetometers and GPS receiver. Basically, from ideal measurements, the model must simulate the actual measurements with the main characteristic errors of the sensors.

A model that analyses the triaxial sensors (accelerometers, gyros and magnetometer) is described in (Lima, 2013). The model considers the following error sources: misalignment and crosssensitivity of the axes, scale factor, noise, bias and quantization during the $A / D$ conversion. So, the measure obtained from the model of sensors, $\tilde{m} \in \Re^{3 \times 1}$, can be written from ideal measurement, $m \in \Re^{3 \times 1}$, by

$$
\tilde{m}=f_{A / D}(S(R m)+B+N)
$$

where $S \in \Re^{3 \times 3}$ is the matrix that characterizes the scale factor and also the cross-sensitivity error; $R \in \Re^{3 \times 3}$ is the matrix that models the misalignment between the axes; $B \in \Re^{3 \times 1}$ is the vector that describes the bias error; $N \in \Re^{3 \times 1}$ is the vector with the measurement noise, and finally, the function $f_{A / D}$ characterizes the quantification in the A/D conversion.

The values for the parameters used in the modeling of the sensors approached in this work are obtained from (Lima, 2013). Some of them are found experimentally and others are obtained from sensor datasheet. The information about the scale factor, cross sensibility, misalignment and quanti_cation are obtained from the datasheets of the sensors: accelerometers ${ }^{2}$, gyros ${ }^{3}$ and magnetometer ${ }^{4}$. These values are shown in Table 2.

The information about the noise and bias were obtained experimentally by the Allan's variance method (lozan et al., 2010). The estimated noise level and bias are shown in the Table 3. 
Table 2: Information from Sensor datasheets

\begin{tabular}{|c|c|c|c|}
\hline Parameter & Accelerometer & Gyro & Magnetometer \\
\hline Scale Factor & $10 \%$ & $6 \%$ & $5 \%$ \\
\hline Cross sensibility & $1 \%$ & $2 \%$ & $0,2 \%$ \\
\hline Misalignment & $0,1^{\circ}$ & $0,1^{\circ}$ & - \\
\hline A $/$ D Resolution & 10 bits & 16 bits & 12 bits \\
\hline Quantification & $0,0039 \mathrm{~g}$ & $0,0092 \% / \mathrm{s}$ & $0,0012 \mathrm{Ga}$ \\
\hline
\end{tabular}

Table 3: Information from experiments and Allan's variance method

\begin{tabular}{|c|c|cc|cc|} 
Sensor & Axis & \multicolumn{2}{|c|}{ Noise variance } & \multicolumn{2}{c|}{ bias } \\
\hline \multirow{3}{*}{ Accelerometer } & $a_{x}$ & $223,59 \times 10^{-9}$ & & $-28,95$ & \\
& $a_{y}$ & $207,80 \times 10^{-9}$ & $\left(\mathrm{~m} / \mathrm{s}^{2}\right)^{2}$ & $-20,10$ & $\mathrm{mg}$ \\
& $a_{z}$ & $266,29 \times 10^{-9}$ & & 13,69 & \\
\hline \multirow{3}{*}{ Gyro } & $b_{x}$ & $32,93 \times 10^{-6}$ & & $-2,835$ & \\
& $b_{y}$ & $68,81 \times 10^{-6}$ & $(0 / \mathrm{s})^{2}$ & 4,345 & $0 / \mathrm{s}$ \\
& $b_{z}$ & $30,67 \times 10^{-6}$ & & $-0,728$ & \\
\hline \multirow{3}{*}{ Magnetometer } & $h_{x}$ & $48,12 \times 10^{-6}$ & & 0 & $\mathrm{Ga}$ \\
& $h_{y}$ & $44,04 \times 10^{-6}$ & $\mathrm{Ga}^{2}$ & 0 & $\mathrm{Ga}$ \\
& $h_{z}$ & $39,08 \times 10^{-6}$ & & 0 & \\
\hline
\end{tabular}

The GPS receiver provides an estimate for the velocity and acceleration in the NED referential.

In this case, our modeling considers only the noise as source of errors. The noise variance for the velocity and acceleration are obtained from (Zhou et al., 2012) and shown in Table 1. However, we need to consider that the data acquisition rate for the GPS receiver is lower than others sensors. Because of that, the model for the GPS makes a decimation of 10 of the output signal to represent it with more fidelity.

\subsection{SIMULATION ENVIRONMENT}

The ideal values for the measurements are obtained by an aircraft dynamic model. The data are generated with ight simulations, in which a small aircraft is modeled as an rigid body with six degrees of freedom (6DOF) (Stevens and Lewis, 2003). Beyond the ideal measurements of the sensors, the ight simulation also returns the ideal values of attitude $(\phi, \theta$ e $\psi)$ for comparison with the estimates of the algorithms analyzed, as illustrated in the Figure 3. The simulated data were generated with the software MATLAB at the rate of $50 \mathrm{~Hz}(20 \mathrm{~ms})$. 


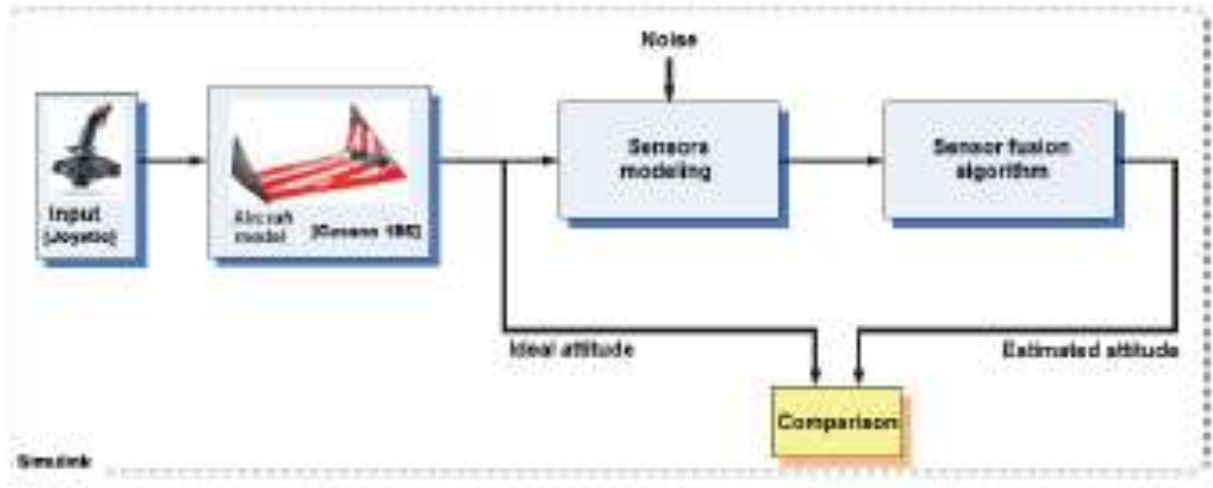

Figure 3: Simulation owchart.

Adapted from (Lima, 2013).

The algorithm is analyzed in three ight simulations with di_erent maneuvers. The first ight test simulates leveled straight ight, a simple condition just to verify the operation of the algorithm.

In the second ight simulated, there is a command in the elevator which characterizes a longitudinal acceleration in the aircraft capable of distorting the accelerometer measures. Finally, the third ight is composed by typical maneuvers, such as rise, curve and descent.

The parameters used by the algorithm SRUKF7s are the initial state estimate and the values of uncertainties. These parameters were tuned from the noise variances observed in the Table 3.

The values were slightly tuned until the errors between the estimated and ideal attitude were consistent with the covariance. The mean and the covariance matrix for the initial estimate are

$$
\begin{aligned}
& \hat{x}_{0 \mid 0}=\left[\begin{array}{lllllll}
1 & 0 & 0 & 0 & 0 & 0 & 0
\end{array}\right]^{T} \text {, } \\
& P_{0 \mid 0}=\left[\begin{array}{cc}
10^{-3} \cdot I_{4 \times 4} & 0_{3 \times 4} \\
04 \times 3 & 10^{-2} \cdot I_{3 \times 3}
\end{array}\right] \text {. }
\end{aligned}
$$

The variances used in the algorithm are shown in the Table 1.

\subsection{ANALYSIS OF THE SIMULATED RESULTS}

The attitude estimated by SR-UKF7s and mEKF7s algorithms and the ideal attitude are shown in the Figures 4,5 and 6. Furthermore,the ideal and estimated values for the gyro bias for the third ight simulation are shown in the Figure 7. The quality of the attitude estimate is measured by the RMSE index (root mean square error), given by 


$$
R M S E_{i}=\sqrt{\frac{1}{N} \sum_{k=1}^{N}\left(x_{i, k}-\hat{x}_{i, k}\right)^{2}},
$$

where $\mathrm{N}$ is the number of samples, $x_{i, k}$ is the ideal value and $\hat{x}_{i, k}$ is the estimated value of the $\mathrm{i}$-th entry of the state vector. For this analysis, the algorithms SR-UKF7s and mEKF7s use the same parameters values described in Section 5.2. The RMSE index for both algorithms in the three ight simulations are shown in the Table 4.

Table 4: RMSE for attitude estimates

\begin{tabular}{|c|c|c|c|c|}
\hline Flight & Algorithm & $\phi$ & $\theta$ & $\psi$ \\
\hline \multirow{2}{*}{1} & mEKF7s & $1,00^{\circ}$ & $0,52^{\circ}$ & $0,94^{\circ}$ \\
\cline { 2 - 5 } & SR-UKF7s & $0,51^{\circ}$ & $0,64^{\circ}$ & $0,51^{\circ}$ \\
\hline \multirow{2}{*}{2} & mEKF7s & $1,43^{\circ}$ & $1,07^{\circ}$ & $1,49^{\circ}$ \\
\cline { 2 - 5 } & SR-UKF7s & $0,62^{\circ}$ & $0,80^{\circ}$ & $0,57^{\circ}$ \\
\hline \multirow{2}{*}{3} & mEKF7s & $4,15^{\circ}$ & $2,41^{\circ}$ & $3,91^{\circ}$ \\
\cline { 2 - 5 } & SR-UKF7s & $1,09^{\circ}$ & $0,90^{\circ}$ & $1,00^{\circ}$ \\
\hline
\end{tabular}
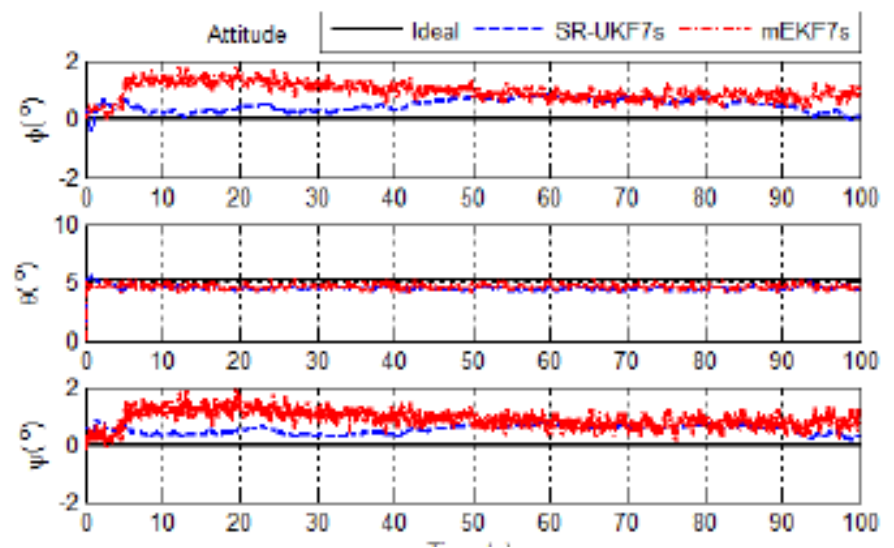

Figure 4: Attitude estimation for ight 1
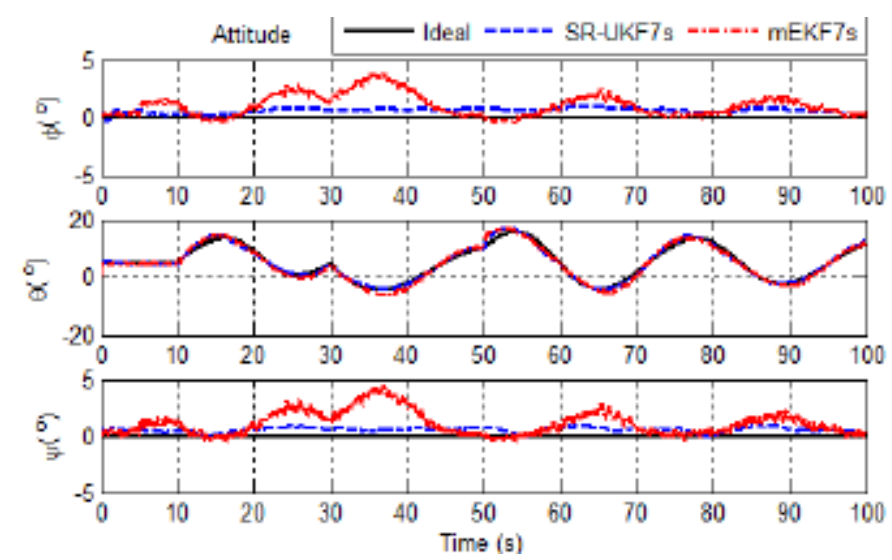

Figure 5: Attitude estimation for ight 2 

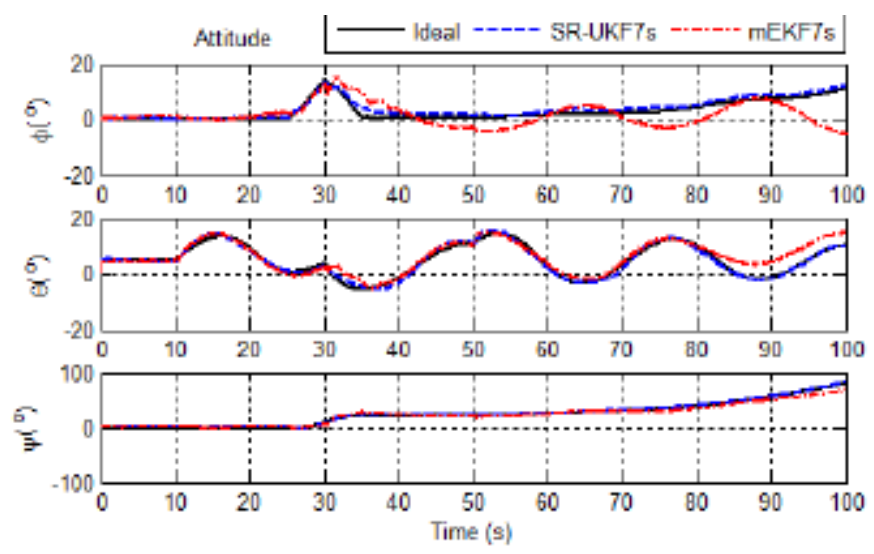

Figure 6: Attitude estimation for ight 3

In general, the attitude estimated by the SRUKF7s yielded lower values for the RMSE index.

The sum of indices for the three angles with SRUKF7s is about 32\% lower than mEKF7s for the first ight simulation, $50 \%$ for the second and $71 \%$ for the third. It shows that the SR-UKF7s maintained a good estimation even when increasing the
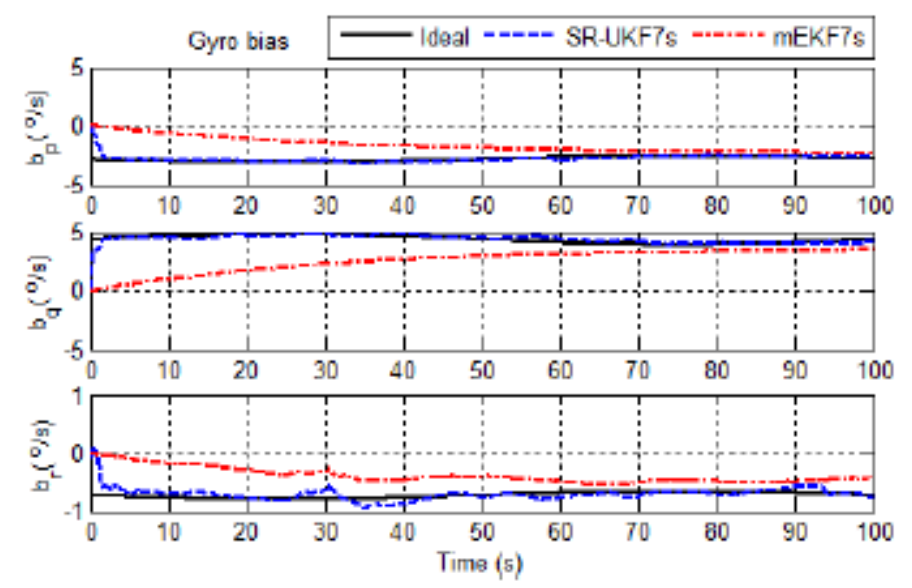

Figure 7: Bias estimation for ight 3

complexity of the maneuvers.

However, the unscented approach usually is more computationally expensive than EKF. So, it is expected that the SR-UKF7s takes more processing time than mEKF7s. In fact, in the three ight simulations, the mean of processing time spent in each sampling time is 5:6ms and 1:0ms for

SR-UKF7s and mEKF7s, respectively. These are the processing times in MATLAB/Simulink with processor Intel Core 2 Duo $1: 83 \mathrm{GHz}$ and $2 \mathrm{~GB}$ ofRAM memory. The processing time is an important point for implementation in hardware. 
The consistence of the Kalman algorithm can be verified by the graph that confronts the error of each state variable with their respective deviations $(\sigma)$, also estimated by the algorithm. For the third ight simulation, the errors of the Euler angles and their respective limits of $\pm 3 \sigma$ are shown in Figure 8 . Note that, the errors of the estimate are within the range of $\pm 3 \sigma$ which indicates that the estimates are consistent.

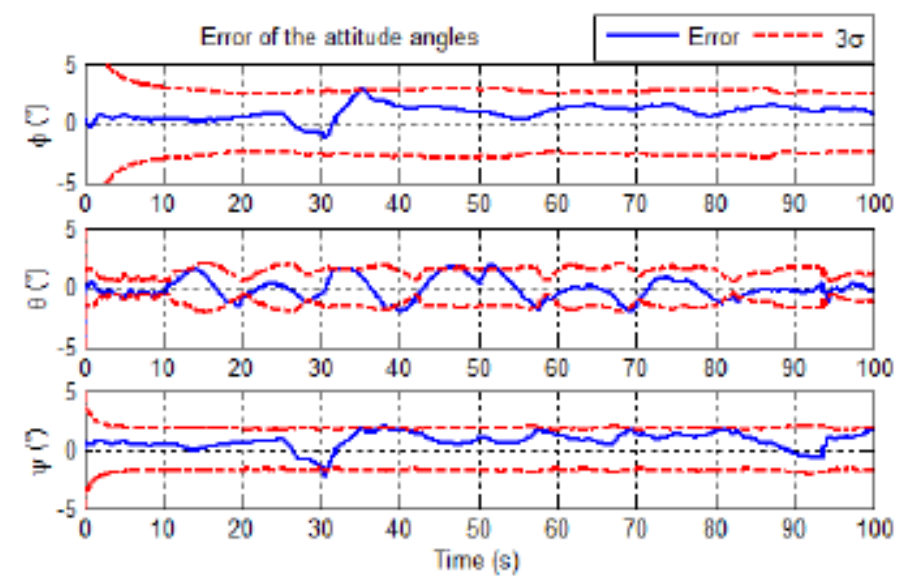

Figure 8: SR-UKF7s: Attitude error for ight 3

One of the main contributions of the implementation proposed in this work is the use of the unscented approach in the pre-processing step of measurements, as described in Section 4.2. In this case, the covariance matrix of measurements from the viewpoint of the SR-UKF, Rk, is recalculated at each iteration using the unscented approach.

The elements of the main diagonal of the matrix $R_{k}$, along the third ight simulation, can be observed in the innovation graph, which is shown in Figure 9. Note that, the innovation remained within the range of $\pm 3 \sigma$, which indicates that the result of the pre-processing step is consistent.

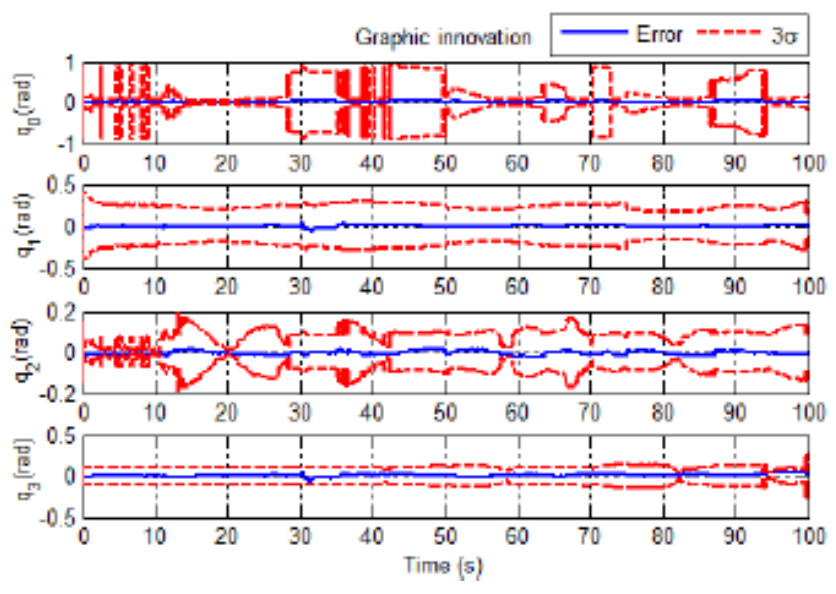

Figure 9: SR-UKF7s: Innovation for ight 3 


\section{CONCLUDING REMARKS}

In this paper, we propose the implementation of an attitude estimator algorithm that uses the unscented approach. The algorithm, called SRUKF7s, was analyzed in simulation environment and compared with the EKF-based algorithm implemented at (Lima, 2013), called mEKF7s. Both algorithms use measurements from accelerometers, gyros, magnetometers and GPS receivers.

These sensors address errors sources, such as misalignment, cross sensibility, bias and noise, which were modeled according to their datasheets and experimental tests. Furthermore, one of the main contributions of this work is to apply the unscented transform to the pre-processing of measurements. Three ight simulations were tested and the attitude estimated by the two algorithms is compared with the true values. The SR-UKF7s yielded better RMSE indexes for attitude and bias estimations. For SRUKF7s, the sum of RMSE indexes for the three Euler angles was 32\%, 50\% and 71\% lower than mEKF7s at first, second and third ight simulations, respectively. However, the average processing time spent for SR-UKF7s is about five times larger than it is for mEKF7s.

Therefore, from simulation environment, it is suggested that the unscented approach can improve the attitude estimation, even if it costs a larger processing time compared to EKF.

\section{ACKNOWLEDGEMENTS}

This work has been partially supported by CNPq, FINEP and FAPEMIG. We also thank to the PDVA research group for helpful assistance. 


\section{REFERENCES}

Bae, J. and Kim, Y. (2010). Attitude Estimation for Satellite Fault Tolerant System Using Federated Unscented Kalman Filter, Int J. of Aeronautical e Space Sci. 11(2):80-86.

Bo, A. P. L. and Borges, G. A. (2007). Sistema de baixo custo para determinação da atitude com aplicação em VANTs, VIII Simpósio Brasileiro de Automação Inteligente (SBAI), 2007(1):1-6.

Diebel, J. (2006). Representing Attitude: Euler Angles, Unit Quaternions, and Rotation Vectors, Matrix, Citeseer. Hemerly, E. M. and Schad, V. R. (2004). Sistema de navegação de baixo custo baseado na fusão INS/GPS usando filtro de Kalman, XV Congresso Brasileiro de Automática.

Iozan, L., Rusu, C., Collin, J. and Takala, J. (2010). A Study of the External Factors that A_ect the Measurement Data of a MEMS Gyroscope Sensor - Towards an Inertial Navigation System, Electronics and Telecommunications (ISETC), 9th International Symposium, p. 81-84. IEEE.

Jang, J. and Liccardo, D. (2006). Automation of Small UAVs using a Low Cost MEMS Sensor and Embedded Computing Platform, IEEE/AIAA 25th Digital Avionics Systems Conference. p. 1-9.

Julier, S. (2002). The scaled unscented transformation, Proceedings of the American Control Conference, 6(1):4555-4559.

Lima, R. R. (2013). Desenvolvimento de uma Cabe_ca Sensora para Veículos éreos Não Tripulados, Dissertação de Mestrado. Programa de Pós Graduação em Engenharia Elétrica, UFMG. Ma, D. M., Shiau, J. K., Wang, I. C. and Lin, Y. H. (2012).

Attitude Determination Using a MEMS-Based Flight Information Measurement Unit, Sensors 12(1):123.

Merwe, R. v. d. and Wan, E. A. (2001). The Square-Root Unscented Kalman Filter for State and Parameter- Estimation, Oregon Graduate Institute of Science and Technology. 6(1):3461-3464.

Shin, E. (2004). A Quaternion-Based Unscented Kalman Filter for the Integration of GPS and MEMS INS, Proceedings of the 17th International Technical Meeting of the Satellite Division of The Institute of Navigation.

Simon, D. (2006). Optimal State Estimation - Kalman, H1 and nonlinear approaches, John Wiley \& Sons, Inc. Simon, H. and Arasaratnam, I. (2009). Cubature Kalman Filters, IEEE Trans. Automat. Contr. 54(6):1254- 1269.

Stevens, B. L. and Lewis, F. L. (2003). Aircraft Control and Simulation, JohnWiley \& Sons, Inc. 2rd Edition, Canada.

Tang, X., Liu, Z. and Zhang, L. (2012). Square-root quaternion cubature Kalman_Itering for spacecraft attitude estimation, Acta Astronautica, 76(1):84-94.

Teixeira, B. O., Chandrasekar, J., T^^orres, L. A. and Aguirre, L. A. (2009). State estimation for linear and non-linear equality-constrained systems, International Journal of Control, 82(5):918-936. 
Terra, G. (2013). Fusão Sensorial para um Miniveículo A éreo não- Tripulado, Trabalho Final de graduação em Engenharia de Controle e Automação - Escola de Engenharia - UFMG.

Zhou, J., Knedlik, S. and Lo_eld, O. (2012). INS/GPS for High-Dynamic UAV-Based Applications, International Journal of Navigation and Observation, 2012(1):1-11. 


\section{Capítulo 3}

\section{doi $10.37423 / 211105005$}

\section{ESTABILIZAÇÃO DE UM PÊNDULO INVERTIDO USANDO CONTROLADOR H2 CONTÍNUO}

ADRIANO BRUNO FRUTUOSO

ANDRÉ HENRIQUE SANTOS

DIEGO CÂMARA

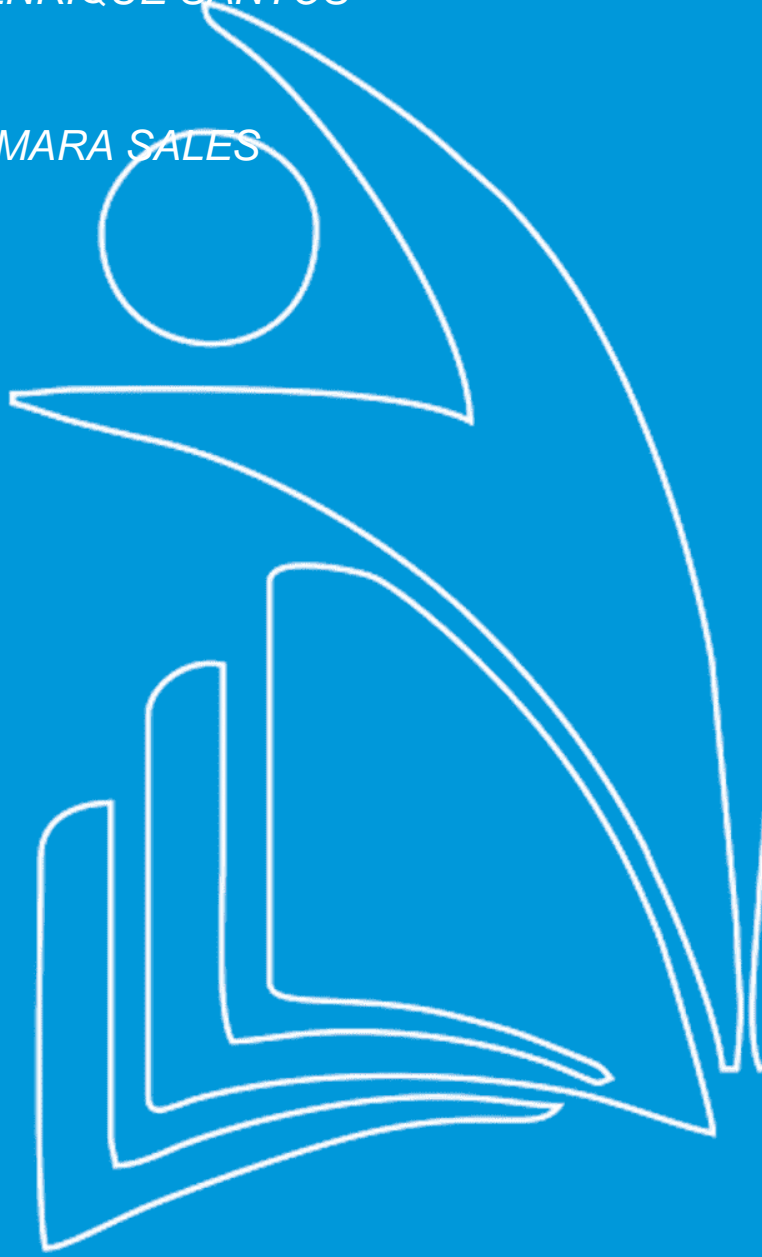

INSTITUTO FEDERAL DO AMAZONAS

UNIVERSIDADE FEDERAL DO AMAZONAS

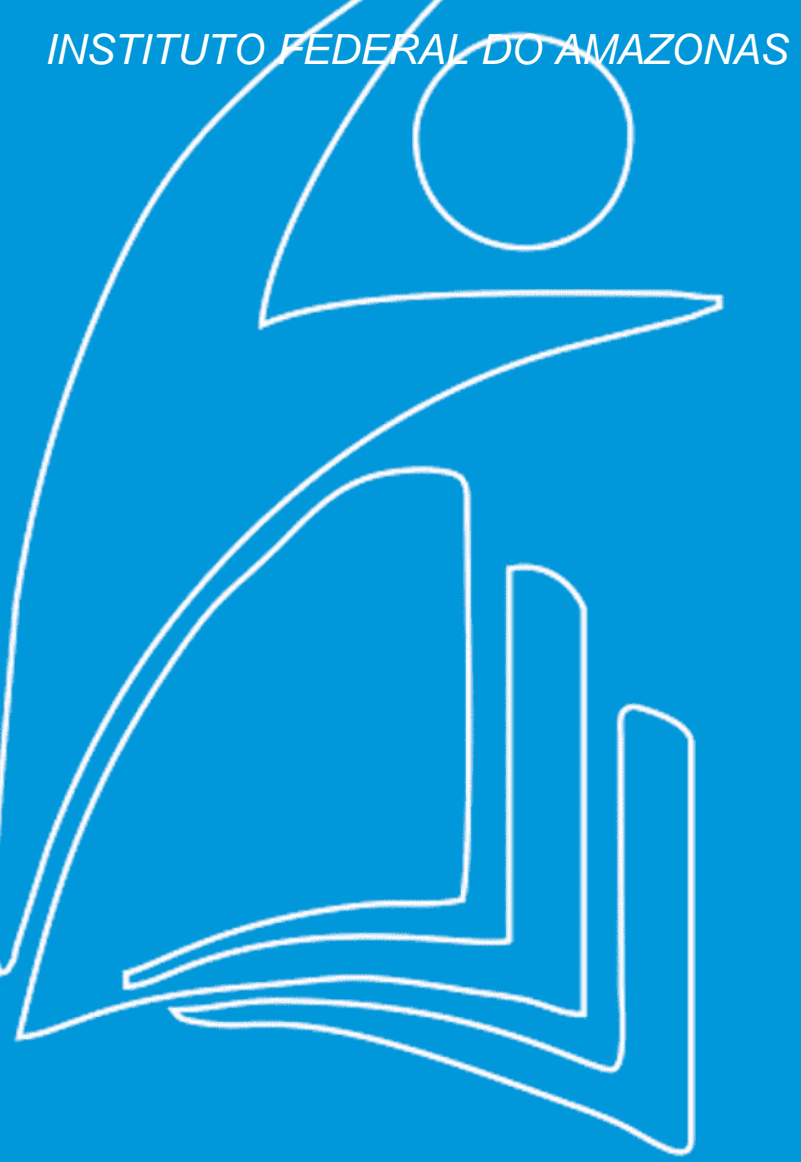


Resumo: O pêndulo invertido trata-se de um sistema que apresenta características dinâmicas instáveis e vem sendo uma planta utilizada para investigar o desempenho de várias técnicas de controle. Neste artigo é apresentado um projeto de um controlador $\mathrm{H} 2$ para estabilização de um pêndulo invertido montado sobre uma plataforma móvel linear. A modelagem do sistema é realizada através das Leis de Newton. Para estimar as velocidades do pêndulo e do carrinho foi projetado um observador de estados com-pleto. Na síntese do controlador $\mathrm{H} 2$, é adotada a abordagem por Linear Matrix Inequalities. Por fim, são apresentados os resulta-dos por meio de simulações computacionais e testes experimentais para avaliar o desempenho do controlador proposto e validar a estratégia de controle adotada.

Palavras-chave: Pêndulo invertido, plataforma móvel, controle H2, Linear Matrix Inequalities. 


\section{INTRODUÇÃO}

O pêndulo invertido é um típico exemplo de sis-tema intrinsicamente instável, onde o estudo e o controle de sua dinâmica de movimento podem ser utilizados em situações que envolvam a manutenção do equilíbrio, tais como o andar de um robô e o con-trole dos propulsores de um foguete (Anderson, 1989).

Diversas estratégias baseadas em teorias de controle clássicas, modernas e inteligentes já foram propostas para solucionar o problema de equilibrar o pêndulo invertido (Roshdy, 2012). Em (Anderson, 1989) é aplicado o método de redes neurais na aprendizagem da dinâmica do pêndulo. Em (Pannil, 2008) é apre-sentado um controlador ótimo H2 discreto para esta-bilização do pêndulo. Em (Lee, 2009) é proposto um algoritmo de controle denominado PSID (Proporcion - Second - Proporcion - Integral - Differential) que é uma modificação do algoritmo de controle PID (Proporcional - Integral - Derivativo) tradicional. Em (Roshdy, 2012), é realizado um controlador por realimentação de estados com fator de separação de polos.

A proposta deste trabalho é projetar um controlador ótimo $\mathrm{H} 2$ contínuo cuja síntese é realizada a partir da resolução de um problema de otimização convexo, apresentado sob a forma de um conjunto de inequa-ções matriciais lineares (LMIs). A solução do pro-blema de otimização reproduz a mesma solução quando se utiliza a abordagem por Riccati, desde que o sistema padrão em malha fechada seja precisamen-te conhecido (Aguirre, 2007).

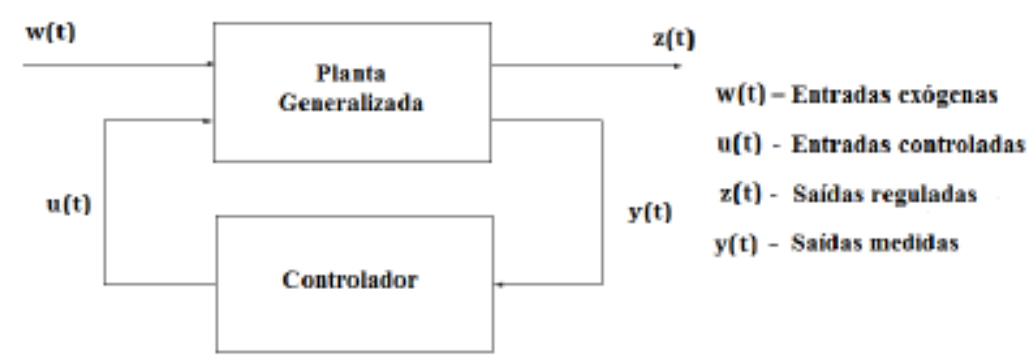

Figura 1: Sistema Padrão em malha fechada

O sistema padrão em malha fechada não apresentará incertezas, sendo a saída regulada influenciada so-mente pelos sinais de controle e de perturbação. Assim, o objetivo do controlador é somente estabili-zar o sistema padrão e atenuar o efeito do sinal de perturbação na saída regulada, a partir da minimiza-ção da norma $\mathrm{H} 2$ referente à relação entre a saída regulada e o sinal de perturbação. 
Também é abordada neste trabalho, a modelagem matemática do pêndulo invertido utilizado no teste experimental da estratégia de controle proposta. Além disso, foi projetado um observador de estados para estimar os estados da planta que não puderam ser mensurados.

Para validar o desempenho do controlador projetado para o pêndulo invertido, foram realizadas simula-ções computacionais e testes práticos. A simulação computacional foi realizada com o auxílio do ambi-ente de simulação do Matlab denominado Simulink. Nos testes práticos, foram utilizados a plataforma de teste IP02 e o software QUARC, todos da Quanser Inc.

\section{MODELAGEM MATEMÁTICA}

A Figura 2 mostra o esquema de um pêndulo in-vertido sobre uma plataforma móvel, as coordenadas adotadas e as forças atuantes no sistema.

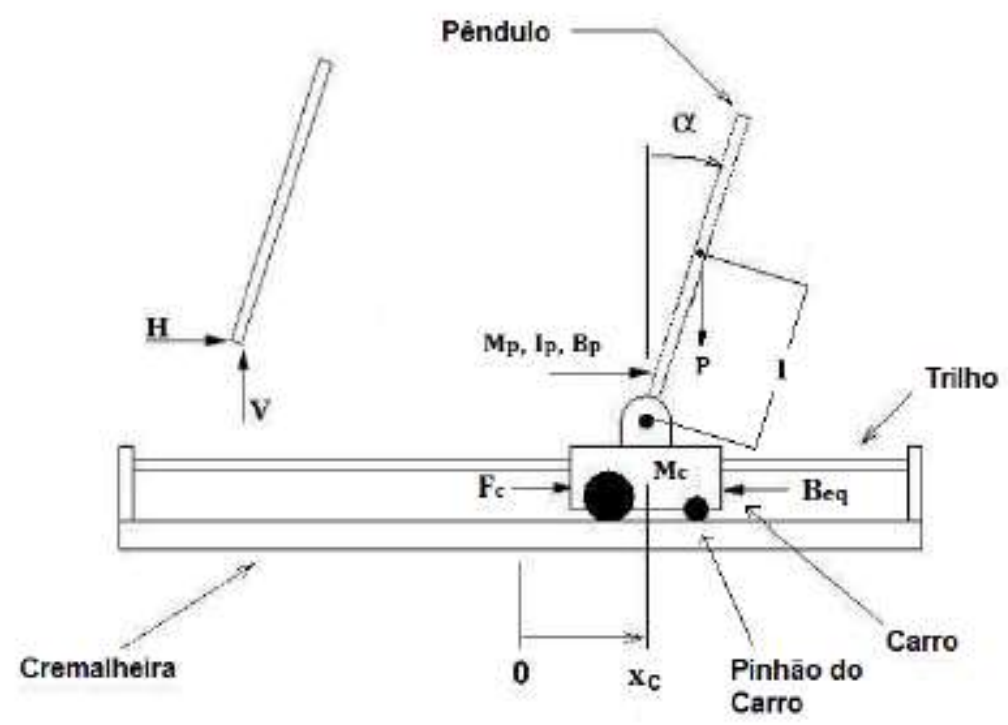

Figura 2: Pêndulo Invertido sobre carrinho. Fc $>0$ (para direita) e $\alpha<0$ (sentido horário)

As equações do movimento do pêndulo e do carrinho foram obtidas utilizando as Leis de Newton. Para o pêndulo, considere o diagrama de corpo livre ilustra-do na Figura 3: 


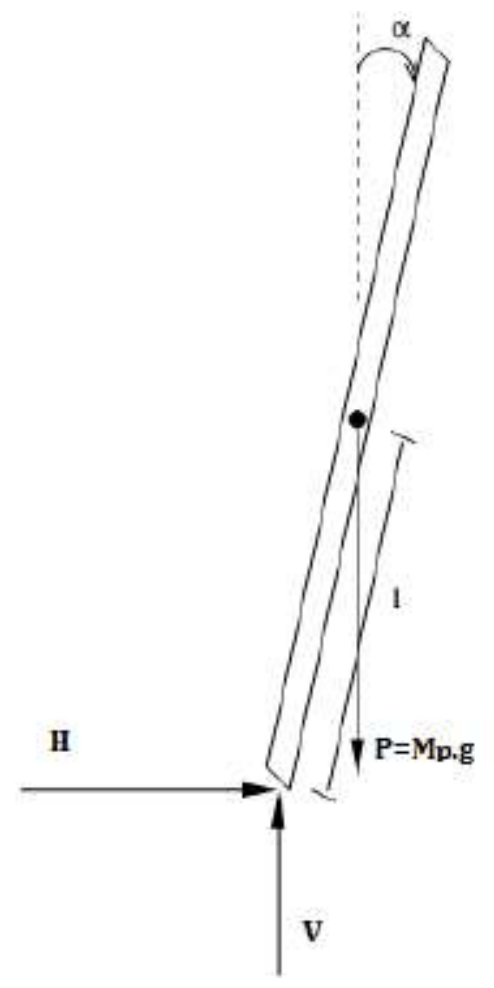

Figura 3: Diagrama de Corpo Livre do pêndulo

Aplicando a Segunda Lei de Newton para o conjunto de forças que atuam no pêndulo obtém-se:

$$
\begin{aligned}
& -\mathrm{M}_{\mathrm{P}} \cdot \mathrm{l} \cdot \ddot{\alpha} \cdot \cos (\alpha)+\mathrm{M}_{\mathrm{P}} \cdot \mathrm{l} \cdot(\dot{\alpha})^{2} \cdot \sin (\alpha)+\mathrm{M}_{\mathrm{P}} \cdot \ddot{\mathrm{x}}_{\mathrm{c}}=\mathrm{H} \\
& -\mathrm{M}_{\mathrm{P}} \cdot \mathrm{l} \cdot \ddot{\alpha} \cdot \sin (\alpha)+\mathrm{M}_{\mathrm{P}} \cdot \mathrm{l} \cdot(\dot{\alpha})^{2} \cdot \cos (\alpha)+\mathrm{M}_{\mathrm{P}} \cdot \mathrm{g}=\mathrm{V}
\end{aligned}
$$

onde Mp é a massa do pêndulo, I é a distância do eixo que une o pêndulo ao carrinho até o centro de gravidade, $\mathrm{H}$ e V são forças que o carrinho exerce sobre o pêndulo na horizontal e vertical, respectivamente, g é a constante gravitacional, $\alpha$ é ângulo do pêndulo e xc é a posição do carrinho.

O torque resultante em torno do centro de gravidade do pêndulo é:

$$
I_{P} \cdot \ddot{\alpha}=V \cdot l \cdot \sin (\alpha)+H \cdot l \cdot \cos (\alpha)-B_{P} \cdot \dot{\alpha}
$$

onde Ip é a inércia do pêndulo em torno do centro de gravidade e Bp é o coeficiente de amortecimento viscoso em relação ao eixo do pêndulo. Substituindo (1) e (2) em (3):

$$
\begin{aligned}
& \mathrm{I} \cdot \ddot{\alpha}=\mathrm{M}_{\mathrm{p}} \cdot \mathrm{l} \cdot \sin (\alpha) \cdot\left[-\mathrm{l} \cdot \ddot{\alpha} \cdot \sin (\alpha)-\mathrm{l} \cdot(\dot{\alpha})^{2} \cdot \cos (\alpha)+\mathrm{g}\right]+ \\
& \mathrm{M}_{\mathrm{p}} \cdot \mathrm{l} \cdot \cos (\alpha) \cdot\left[-\mathrm{l} \cdot \ddot{\alpha} \cdot \cos (\alpha) \cdot(\dot{\alpha})^{2} \cdot \sin (\alpha)+\ddot{\mathrm{x}}_{\mathrm{c}}\right]-\mathrm{B}_{\mathrm{p}} \cdot \dot{\alpha}(4)
\end{aligned}
$$


Note que (4) é não linear. Se for assumido que o desvio de $\alpha$ é próximo de zero os termos( $\dot{\alpha}) 2 \mathrm{e} \alpha . \dot{\alpha}$ podem ser desprezados (Ogata, 2003). Considerando $\cos (\alpha) \cong 1$ e $\sin (\alpha) \cong \alpha$, a equação (4) se torna:

$$
\mathrm{I}_{\mathrm{p}} \cdot \ddot{\alpha}=-\mathrm{M}_{\mathrm{p}} \cdot \mathrm{l}^{2} \cdot \ddot{\alpha}+\mathrm{M}_{\mathrm{p}} \cdot \mathrm{l} \cdot \ddot{\mathrm{x}}_{\mathrm{c}}-\mathrm{B}_{\mathrm{p}} \cdot \dot{\alpha}+\mathrm{M}_{\mathrm{p}} \cdot \mathrm{g} \cdot \mathrm{l} \cdot \alpha
$$

A mesma análise pode ser feita para o carrinho a partir do diagrama de corpo livre da Figura 4. Note que as forças verticais foram desconsideradas visto que o carrinho não se move na vertical.

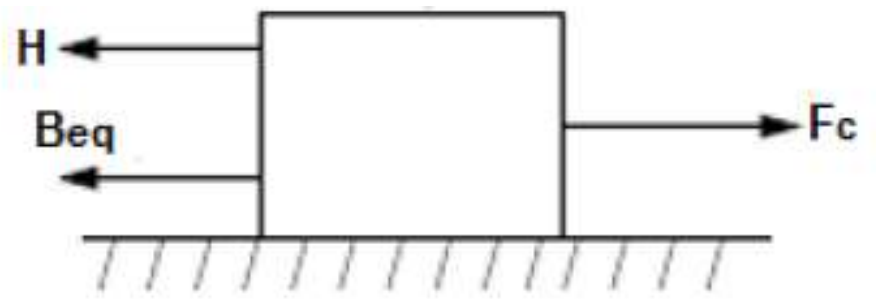

Figura 4: Diagrama de corpo livre da plataforma móvel

A força resultante aplicada no carrinho é:

$$
\begin{aligned}
\left(M+M_{p}\right) \cdot \ddot{x}_{c}= & M_{p} \cdot l \cdot \ddot{\alpha} \cdot \cos (\alpha)-M_{p} \cdot l \cdot(\dot{\alpha})^{2} \cdot \sin (\alpha)- \\
& B_{e q} \cdot \dot{x}_{c}+F_{c}
\end{aligned}
$$

onde $B_{\text {eq }}$ é o coeficiente de amortecimento viscoso visto pelo pinhão do motor acoplado ao carrinho, M é massa total do carrinho (plataforma mais o motor) e Fc é a força do motor aplicada ao carrinho. Lineari-zando a equação (6) obtém-se:

$$
\left(M+M_{p}\right) \cdot \ddot{x}_{c}=M_{p} \cdot 1 \cdot \ddot{\alpha}-B_{e q} \cdot \dot{x}_{c}+F_{c}
$$

Substituindo (7) em (5) e vice-versa, encontram-se as equações lineares do movimento do pêndulo (8) e da plataforma móvel (9):

$$
\begin{gathered}
\ddot{\alpha}=\frac{\left(M+M_{p}\right) \cdot M_{p} \cdot g \cdot l \cdot \alpha}{\left(M+M_{p}\right) \cdot I_{p}+M \cdot M_{p} \cdot l^{2}}-\frac{M_{p} \cdot l \cdot B_{e q} \cdot \dot{x}_{c}}{\left(M+M_{p}\right) \cdot I_{p}+M \cdot M_{p} \cdot l^{2}} \\
-\frac{\left(M+M_{p}\right) \cdot B_{p} \cdot \dot{\alpha}}{\left(M+M_{p}\right) \cdot I_{p}+M \cdot M_{p} \cdot l^{2}}+\frac{M_{p} \cdot l \cdot F_{c}}{\left(M+M_{p}\right) \cdot I_{p}+M \cdot M_{p} \cdot l^{2}} \\
\ddot{x}_{c}=\frac{M_{p}^{2} \cdot l^{2} \cdot g \cdot \alpha}{\left(M+M_{p}\right) \cdot I_{p}+M \cdot M_{p} \cdot l^{2}}-\frac{\left(I_{p}+M_{p} \cdot l^{2}\right) \cdot B_{e q} \cdot \dot{x}_{c}}{\left(M+M_{p}\right) \cdot I_{p}+M \cdot M_{p} \cdot l^{2}} \\
-\frac{M_{p} \cdot 1 \cdot B_{p} \cdot \dot{\alpha}}{\left(M+M_{p}\right) \cdot I_{p}+M \cdot M_{p} \cdot l^{2}}+\frac{\left(I_{p}+M_{p} \cdot l^{2}\right) \cdot F_{c}}{\left(M+M_{p}\right) \cdot I_{p}+M \cdot M_{p} \cdot l^{2}}
\end{gathered}
$$


A força do motor aplicado ao carrinho, Fc, é dada por (Quanser, 2006):

$$
\mathrm{F}_{\mathrm{c}}=-7,74 \cdot \dot{\mathrm{x}}_{\mathrm{c}}+1,72 \cdot \mathrm{V}_{\mathrm{m}}(\mathrm{t})
$$

sendo $V_{m}$ a tensão de armadura do motor.

\section{PROJETO DO CONTROLADOR H2}

Considere o modelo de espaço de estados abaixo:

$$
\begin{aligned}
& \dot{\mathrm{x}}(\mathrm{t})=\mathrm{A} \cdot \mathrm{x}(\mathrm{t})+\mathrm{B}_{\mathrm{u}} \cdot \mathrm{u}(\mathrm{t})+\mathrm{B}_{\mathrm{w}} \cdot \mathrm{w}(\mathrm{t}) \\
& \mathrm{z}(\mathrm{t})=\mathrm{C}_{\mathrm{z}} \cdot \mathrm{x}(\mathrm{t})+\mathrm{D}_{\mathrm{zu}} \cdot \mathrm{u}(\mathrm{t}) \\
& \mathrm{u}(\mathrm{t})=\mathrm{K} \cdot \mathrm{x}(\mathrm{t})
\end{aligned}
$$

Para o sistema modelado no item 2, o modelo por espaço de estados é:

$$
\begin{aligned}
& B_{u}=\left[\begin{array}{c}
0 \\
0 \\
\frac{1,73 \cdot\left(I_{P}+M_{p} \cdot l^{2}\right)}{\left(M+M_{p}\right) \cdot I_{p}+M \cdot M_{p} \cdot l^{2}} \\
\frac{1,73 \cdot M_{p} \cdot 1}{\left(M+M_{p}\right) \cdot I_{p}+M \cdot M_{p} \cdot l^{2}}
\end{array}\right] \\
& B_{W}=\left[\begin{array}{c}
0 \\
0 \\
\frac{-I_{P}+M_{p} \cdot l^{2}}{\left(M+M_{p}\right) \cdot I_{p}+M \cdot M_{p} \cdot l^{2}} \\
\frac{2 \cdot M_{p} \cdot 1+M_{p} \cdot 1}{\left(M+M_{p}\right) \cdot I_{p}+M \cdot M_{p} \cdot l^{2}}
\end{array}\right] \\
& \mathrm{C}_{\mathrm{z}}=\left[\begin{array}{llll}
1 & 0 & 0 & 0 \\
0 & 1 & 0 & 0
\end{array}\right] ; \quad \mathrm{D}_{\mathrm{zu}}=\left[\begin{array}{l}
0 \\
0
\end{array}\right]
\end{aligned}
$$

O projeto do controlador $\mathrm{H} 2$ deve satisfazer a quatro requisitos:

1. Estabilizar o sistema sujeito a duas situações:

- sem perturbação externa;

- uma vez estabilizado o sistema, é aplicada uma perturbação externa w(t) de curta duração na extremidade do pêndulo. 


\section{Resposta dinâmica satisfatória;}

3. Erro de regime estacionário menor que $2^{\circ}$ graus para o pêndulo;

4. Sinal de controle $u(t)$ limitado em -20VDC e 20VDC.

O ganho de realimentação $K$ que possa satisfazer os requisitos acima é obtido resolvendo-se o seguinte problema de otimização convexo (Aguirre, 2007):

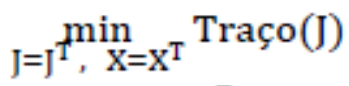

$$
\begin{aligned}
& \text { s.a }\left[\begin{array}{cc}
\mathrm{J} & \mathrm{B}_{\mathrm{w}}{ }^{\mathrm{T}} \\
\mathrm{B}_{\mathrm{w}} & \mathrm{X}
\end{array}\right]>0 \\
& {\left[\begin{array}{cc}
1 & \mathrm{X}(0)^{\mathrm{T}} \\
\mathrm{x}(0) & \mathrm{X}
\end{array}\right] \geq 0} \\
& {\left[\begin{array}{cc}
\mathrm{X} & \mathrm{Z}^{\mathrm{T}} \\
\mathrm{Z} & \mu^{2} . \mathrm{I}
\end{array}\right] \geq 0} \\
& {\left[\begin{array}{cc}
- \text { r.X } & \text { A.X + q.X } \\
(X \cdot A)^{\mathrm{T}}+\text { q.X } & - \text { r.X }
\end{array}\right]<0} \\
& {\left[\begin{array}{cc}
A \cdot X+(X \cdot A)^{\mathrm{T}}+B_{u} \cdot Z+Z^{T} \cdot B_{u}{ }^{\mathrm{T}} & \left(X \cdot C_{z}\right)^{\mathrm{T}}+Z^{\mathrm{T}} \cdot \mathrm{D}_{z u}{ }^{\mathrm{T}} \\
\mathrm{C}_{\mathrm{z}} \cdot \mathrm{X}+\mathrm{D}_{\mathrm{zu}} \cdot \mathrm{Z} & -\mathrm{I}
\end{array}\right]<0}
\end{aligned}
$$

onde q e r são, respectivamente, o centro e o raio da circunferência que delimita a região de alocação dos pólos do sistema realimentado, $x(0)$ é a condição inicial do sistema e $\mu$ é o limitante para a norma do sinal de controle $u(t)$.

\section{SIMULAÇÃO COMPUTACIONAL}

Para uma avaliação prévia do desempenho do controlador $\mathrm{H} 2$, foi realizada uma simulação com o modelo linear do pêndulo invertido. Os valores dos parâmetros do modelo foram:

Tabela 1: Valores dos parâmetros utilizados na simulação do pêndulo invertido

\begin{tabular}{|c|ll|}
\hline Parâmetros & \multicolumn{2}{|l|}{ Valores } \\
\hline$M_{p}$ & 0,127 & {$\left[\mathrm{k}_{\mathrm{g}}\right]$} \\
\hline$l$ & 0,1778 & {$[\mathrm{~m}]$} \\
\hline$I_{p}$ & $1,2 \times 10^{-3}$ & {$\left[\mathrm{~kg} \cdot \mathrm{m}^{2}\right]$} \\
\hline$B_{p}$ & 0,0024 & {$[\mathrm{~N} \cdot \mathrm{m} \cdot \mathrm{s} / \mathrm{rad}]$} \\
\hline$g$ & 9,81 & {$\left[\mathrm{~m} / \mathrm{s}^{2}\right]$} \\
\hline$M_{c}$ & 1,0731 & {$[\mathrm{k} \mathrm{g}]$} \\
\hline$B_{e q}$ & 5,4 & {$[\mathrm{~N} \cdot \mathrm{m} . \mathrm{s} / \mathrm{rad}]$} \\
\hline
\end{tabular}


Assim, temos:

$$
\begin{aligned}
& \dot{x}_{c}=\left[\begin{array}{cccc}
0 & 0 & 1 & 0 \\
0 & 0 & 0 & 1 \\
0 & 0,87 & -11,91 & -0,01 \\
0 & 46,25 & -51,55 & -0,5
\end{array}\right] \cdot x(t)+\left[\begin{array}{c}
0 \\
0 \\
1,56 \\
6,77
\end{array}\right] \cdot u(t)+\left[\begin{array}{c}
0 \\
0 \\
-0,49 \\
70,31
\end{array}\right] \cdot w(t) \\
& z(t)=\left[\begin{array}{llll}
1 & 0 & 0 & 0 \\
0 & 1 & 0 & 0
\end{array}\right] \cdot x(t)
\end{aligned}
$$

Na síntese do controlador, foram adotados os seguintes valores:

Tabela 2: Valores dos parâmetros para síntese do controlador H2.

\begin{tabular}{|l|l|}
\hline Parâmetros & Valores \\
\hline$r$ & 19,5 \\
\hline $\mathrm{q}$ & 20 \\
\hline$\mu$ & 20 \\
\hline $\mathrm{x}(0)$ & {$\left[\begin{array}{llll}0 & 0 & 0 & 0\end{array}\right]^{T}$} \\
\hline
\end{tabular}

Conforme exposto no item 3, o ganho $\mathrm{K}$ é determi-nado resolvendo o problema de otimização dado por (12). A resolução do problema é feita com o auxílio do LMllab, que é uma ferramenta de resolução de LMIs disponível no Matlab. O valor de K encontrado foi:

$$
\mathrm{K}=\left[\begin{array}{llll}
65,79 & -128,49 & 49,09 & -16,49
\end{array}\right]
$$

Pode-se ressaltar que no projeto de controladores que envolvam realimentação de estados, pressupõe-se que os estados da planta a ser controlada estejam disponíveis. Como será abordado no item 5, o IP02 da Quanser dispõe somente de sensores de posição. Desta forma, é necessário projetar um observador de estados para estimar a velocidade angular do pêndulo e a velocidade de deslocamento do carrinho.

Para o projeto do observador, considere a configura-ção proposta na Figura 5: 


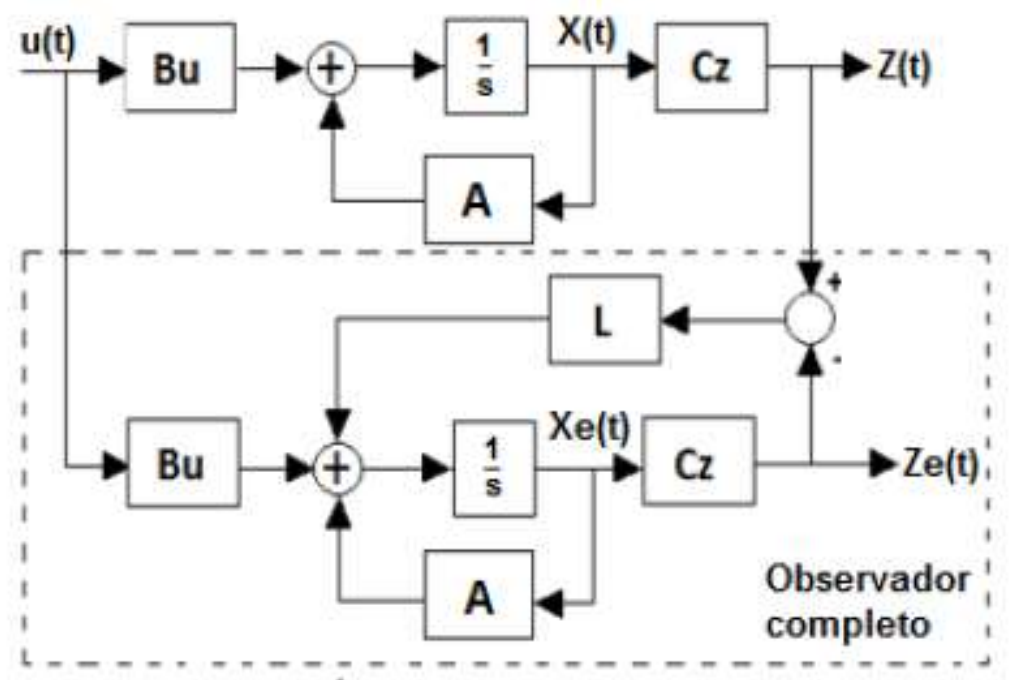

Figura 5: Configuração proposta para o observador de estados.

Deve-se obter o ganho $L$ de tal forma que a dinâmica do erro entre os estados estimados e reais da planta, $x e(t)$ e $x(t)$ respectivamente, convirja para próximo de zero. Além disso, deve ser rápida o bastante para não interferir na dinâmica do controlador. Para tanto, os autovalores de $L$ devem ser negativos e pelo menos 5 vezes o valor dos autovalores do sistema realimenta-do (esse valor de 5 vezes foi escolhido de forma arbitrária).

O valor de L foi calculado resolvendo-se a seguinte equação matricial (Chen, 1999):

$$
\mathrm{TA}-\mathrm{FT}=\mathrm{L}_{0} \cdot \mathrm{C}_{\mathrm{z}}
$$

onde $\mathrm{F}$ contêm os autovalores desejados para a di-nâmica do erro, T é a matriz de Lyapunov e LO= TL. Para o pêndulo invertido, adotou-se:

$$
\mathrm{F}=\left[\begin{array}{cccc}
-100 & 0 & 0 & 0 \\
0 & -100 & 0 & 0 \\
0 & 0 & -75 & 0 \\
0 & 0 & 0 & -75
\end{array}\right] \text { e } \mathrm{L}_{0}=\left[\begin{array}{cc}
1 & 1 \\
0 & 2 \\
-1 & 0 \\
0 & 1
\end{array}\right]
$$

Utilizando a função lyap() do Matlab, obtém-se o valor de T. Portanto, o valor de L calculado foi:

$$
\mathrm{L}=\mathrm{T}^{-1} \cdot \mathrm{L}_{0}=\left[\begin{array}{cc}
163,1 & 0 \\
-51,6 & 174,5 \\
5558,8 & -0,7 \\
-8381,9 & 7459,3
\end{array}\right]
$$

Uma vez que foram encontrados os valores de $\mathrm{K}$ e L, montou-se o circuito da Figura 6 no Simulink. $\mathrm{O}$ observador de estados é mostrado na Figura 7. 


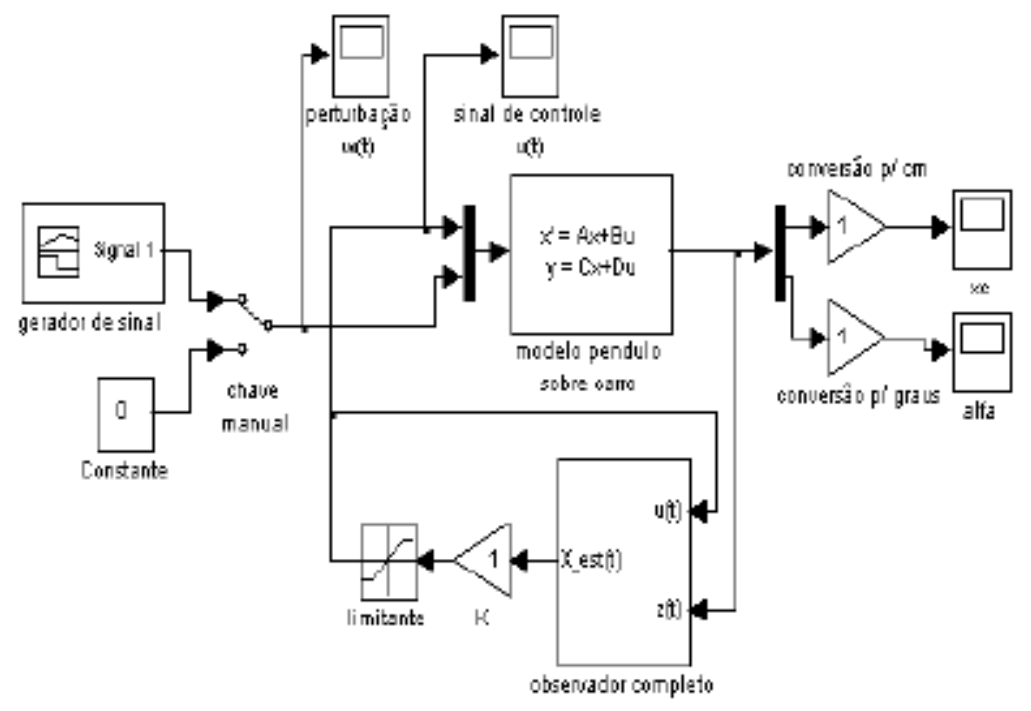

Figura 6: Simulação do Sistema no Simulink

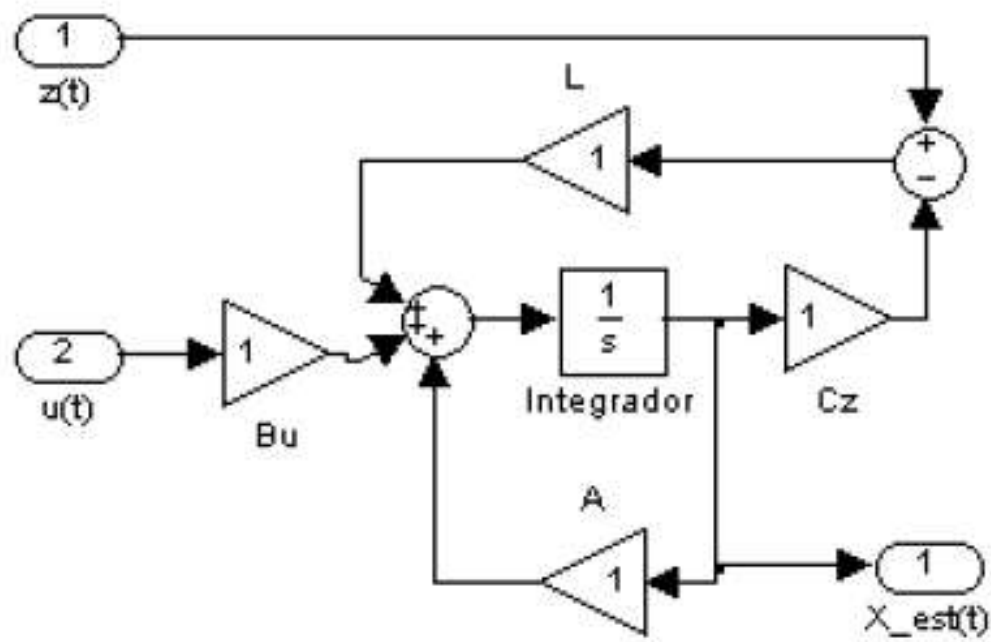

Figura 7: Observador de estados

O resultado da simulação pode ser visualizado na Figura 8. Percebe-se que o controlador projetado estabilizou o pêndulo invertido na posição desejada, ou seja, na posição de $0^{\circ}$. Com relação à resposta transitória, tanto a posição do pêndulo quanto a do carrinho apresentaram tempos de acomodação pe-quenos (próximo de 2 segundos). Em relação ao comportamento do sistema perante a um sinal de perturbação externo w(t), ilustrado na Figura 9, o controlador proposto conseguiu estabilizar o pêndulo. 


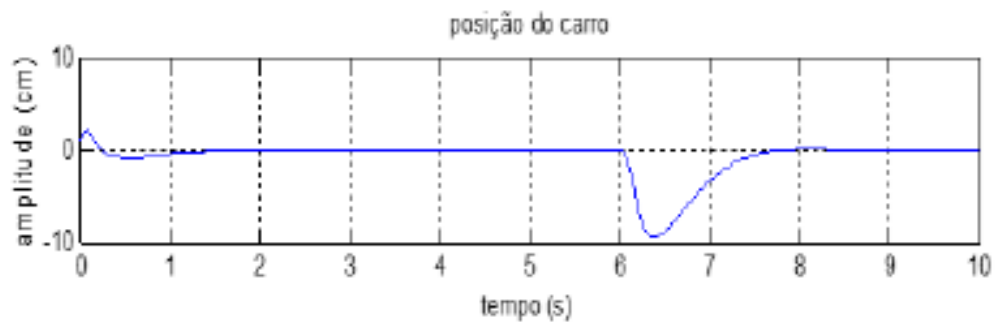

posiçāo do pendulo

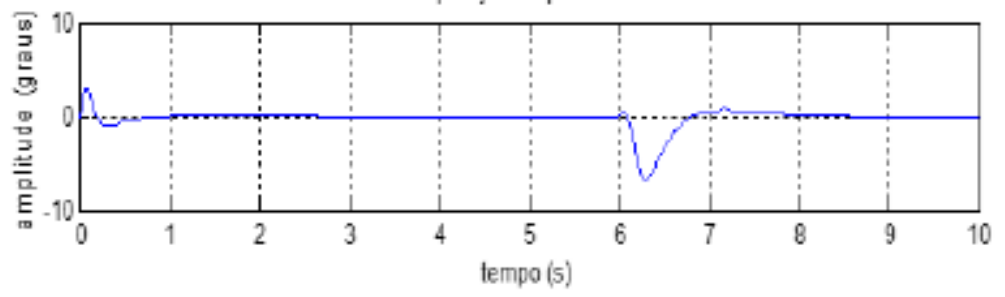

sinal de cortrole u(t)

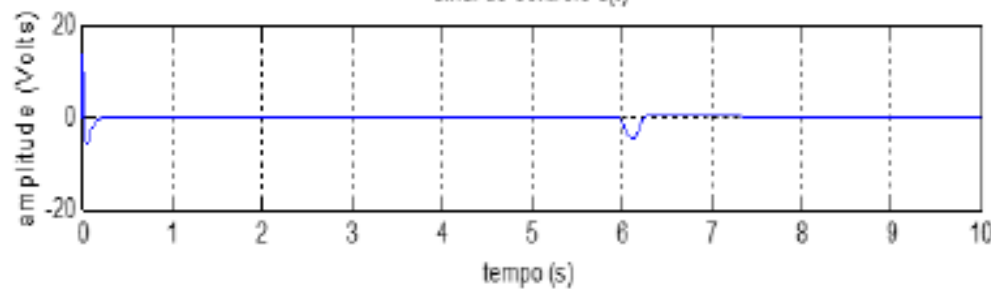

Figura 8: Posições do carrinho e do pêndulo e sinal de controle.

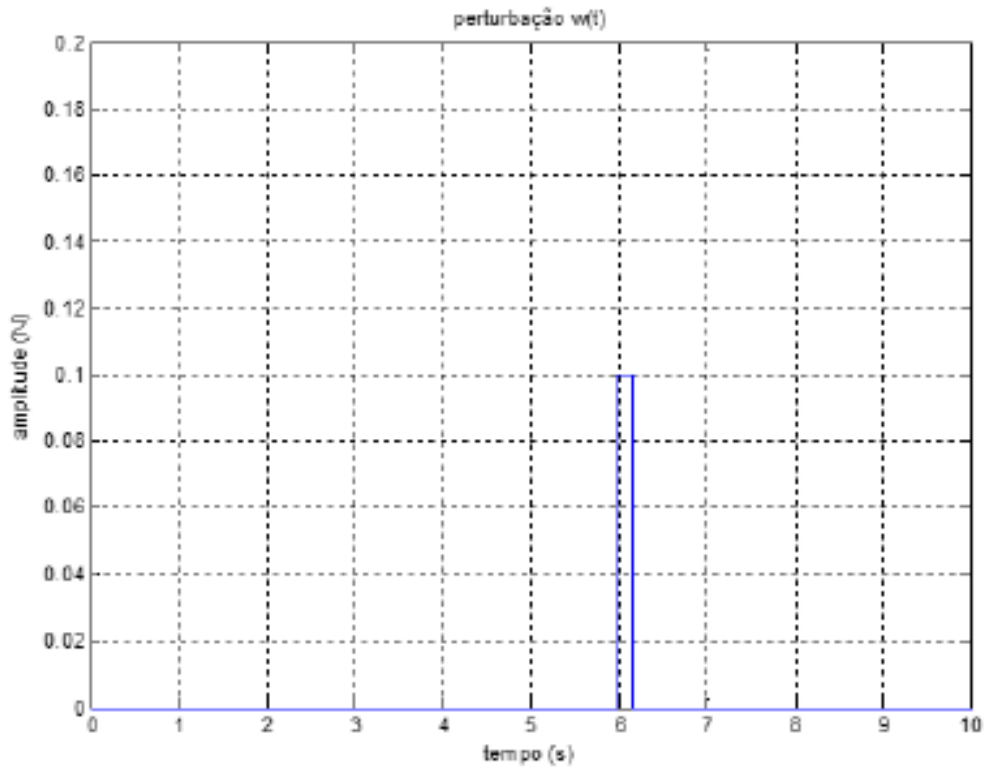

Figura 9: Sinal de perturbação $w(t)$

\section{IMPLEMENTAÇÃO PRÁTICA}

Na verificação experimental do controlador H2 proposto, foi utilizado o IP02 da Quanser (Quanser, 2006). O IP02 é uma plataforma móvel que executa movimentos lineares através de uma cremalheira e um pinhão, onde um servomotor DC transmite torque a plataforma. No IP02 existem dois encoders 
rotati-vos incrementais, que servem para fazer as medições das posições do carrinho e da haste. Com relação à haste, a mesma é acoplada ao IP02 por meio de um eixo perpendicular à direção do movimento da plata-forma. Na Figura 10 é mostrado o IP02 juntamente com a haste.

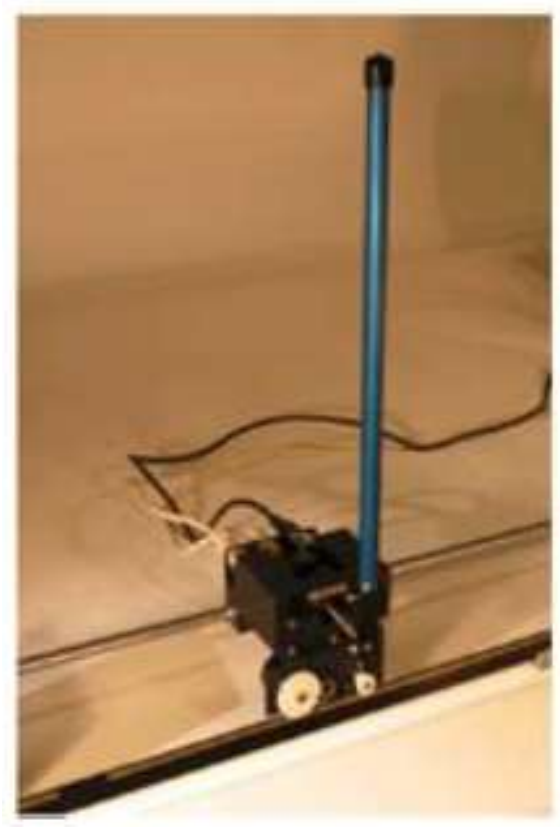

Figura 10: IP02

A leitura dos dados gerados pelos encoders bem como o acionamento do servomotor DC é realizado por intermédio de uma placa que dispõe de converso-res $A / D$ (analógico/digital) e $D / A$ (digital/analógico). Essa placa se comunica com o PC através de uma placa de aquisição de dados denominada Q4. O link entre a placa de aquisição de dados e o Simulink é feito pelo software QUARC. Com ele, é possível controlar o IP02 diretamente no Simulink. As Figu-ras 11, 12 e 13 mostram o esquema de controle do pêndulo invertido, utilizando os blocos do QUARC que possibilitam medir as posições de interesse e acionar o servomotor do carrinho.

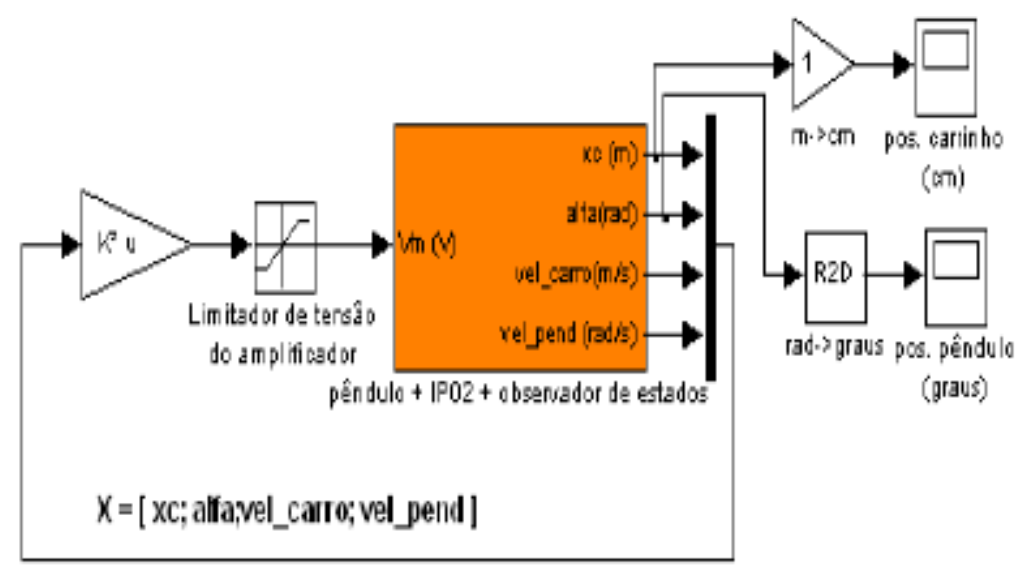

Figura 11: Visão global do sistema realimentado. 


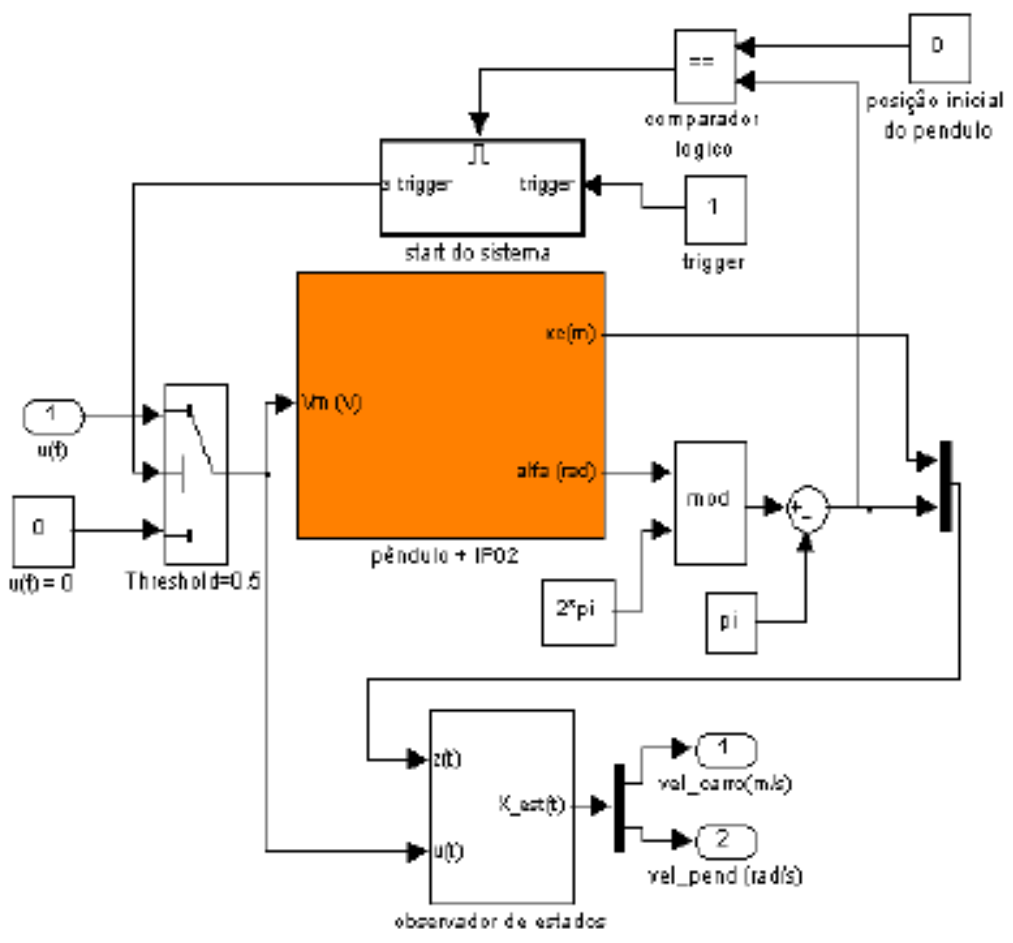

Figura 12: Pêndulo + IP02.

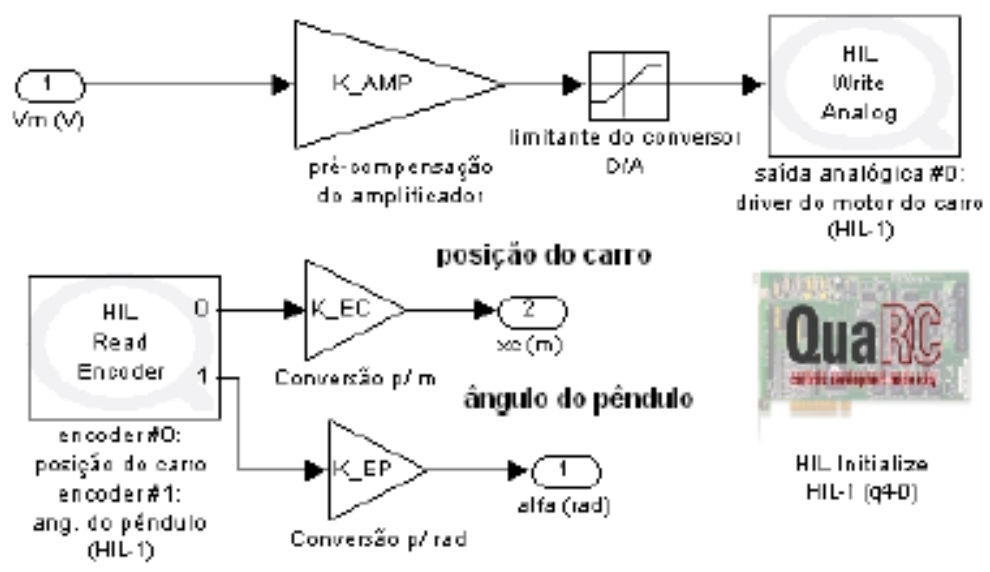

Figura 13: Interface do IP02.

\section{RESULTADOS}

Os gráficos das posições e velocidades da plata-forma móvel e do pêndulo são mostrados nas Figuras 14 e 15.

Com relação ao movimento da plataforma, notou-se um comportamento oscilatório com picos próximos de 5 a -5 centímetros, o que poderia ser um indicio de que o sistema estava no limite de estabilidade. 

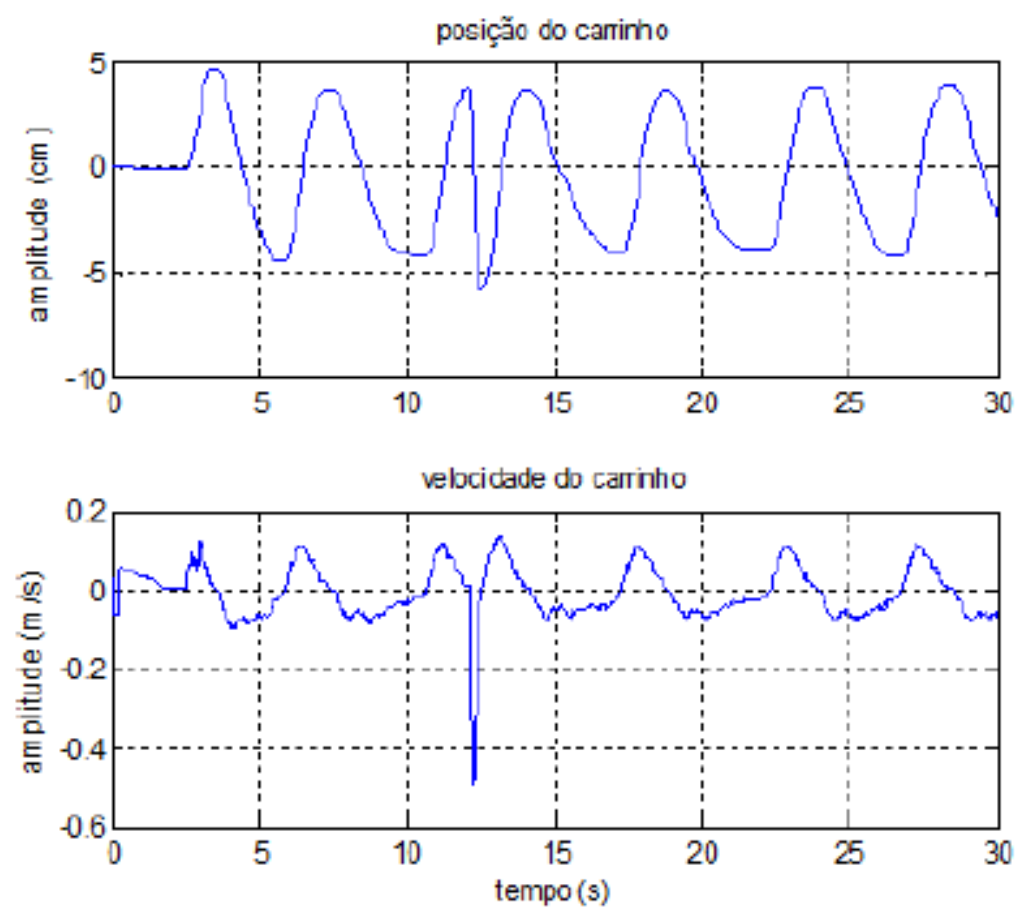

Figura 14: Posição e velocidade do carrinho.
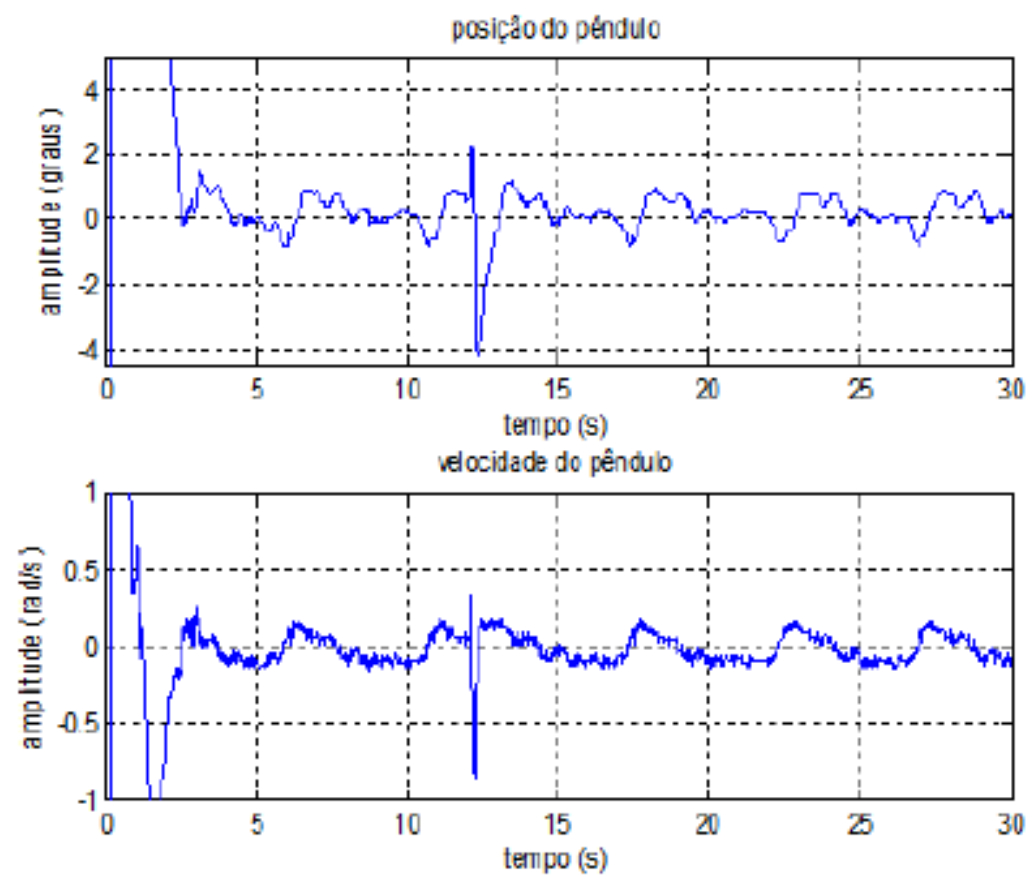

Figura 15: Posição e velocidade do pêndulo.

Para verificar se o sistema estava marginalmente instável, aplicou-se na extremidade do pêndulo uma força externa de baixa intensidade e de curta duração, neste caso o procedimento foi realizado de maneira empírica. O resultado disto foi um aumento súbito da velocidade do carrinho, mas o controlador proposto conseguiu equilibrar o pêndulo, como pode ser ob-servado na Figura 14. 
Portanto, esse resultado mos-trava que o controlador proposto para o pêndulo invertido não só estabilizava o sistema como também conferia ao mesmo alguma robustez a perturbações de baixa intensidade e de curta duração.

Outro resultado importante foi que o projeto do ob-servador de estados apresentou um desempenho satisfatório. Isto porque caso o observador não esti-masse adequadamente as velocidades do pêndulo e do carrinho, o controlador não estabilizaria o sistema.

Também se notou a partir da análise do gráfico da posição do pêndulo, que o mesmo ficou dentro do limite estabelecido no item III. Além disso, vale ressaltar que o sinal de controle não ultrapassou \pm 10 Volts no experimento prático.

A partir dos resultados apontados, pôde-se concluir que o controlador $\mathrm{H} 2$ apresentou desempenho satisfa-tório no que diz respeito a não somente estabilizar, como também conferir ao pêndulo invertido algum grau de robustez.

\section{CONCLUSÃO}

Neste trabalho foi projetado um controlador H2 para estabilizar o pêndulo invertido. Simulações computacionais e testes práticos foram realizados para avaliar o desempenho do controlador proposto.

Os resultados mostraram que o controlador $\mathrm{H} 2$ apre-sentou desempenho satisfatório, atendendo a todos os requisitos de projeto. Entretanto a dinâmica da posi-ção do carrinho poderia ser melhorada, reduzindo a oscilação em torno da posição 0 centímetros. Desta forma como trabalhos futuros é sugerida a melhora do controle da posição do carrinho. 


\section{REFERÊNCIAS BIBLIOGRÁFICAS}

Aguirre, L. A. (2007). Enciclopédia de Automática: Controle \& Automação. Vol 1. Ed. Blucher.

Anderson, C. W. (1989). Learning to Control an Inverted Pendulum Using Neural Networks. IEEE Control Systems Magazine, Vol.9, No. 3; pp. 31- 37.

Chen, C. T. (1999). Linear System Theory and Design. Oxford University Press.

Lee, S. S. and Lee J. M (2009). Robust control of the inverted pendulum and mobile robot. IEEE International Symposium on Assembly and Manufacturing, pp. 398- 401.

Ogata, K. (2003). Engenharia de Controle Moderno. 4 ed. Person Prentice Hall.

Pannil, P. et al. (2008). Discrete optimal H2 controller for Inverted Pendulum System. pp. 1827-1832.

Quanser, I. (2006). IP01 and IP02 Linear Motion Servo Plants - Product Information Sheet L1 - 1 rev.B, Quanser Inc.

Roshdy, A. A et al. (2012). Stabilization of Real Inverted Pendulum Using Pole Separation Factor. MEMS International Conference on Mechanical Engineering and Material Science. Vol. 27, pp. 711-715.

Silva, E. M. e Antunes R. (2010). Controle de um Pêndulo Invertido. 


\section{Capítulo 4}

\section{doi $10.37423 / 211105008$}

\section{SISTEMA DE GERAÇÃO DE ENERGIA EÓLICA COM FILTRO ATIVO PARALELO A PARTIR DO GERADOR SÍNCRONO DE IMÃ PERMANENTE CONECTADO À REDE ELÉTRICA}

Leonardo Pires de Sousa Silva

Denisia de Vasconcelos Mota

Levy Rodrigues Cavalcante

Lucas Taylan Portes Medglros

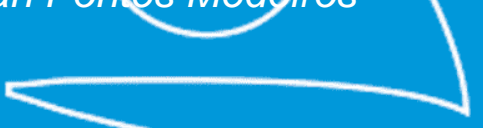

Vanessa Siqueira de Gastro Teixeira

Adson Bezerra Moreira

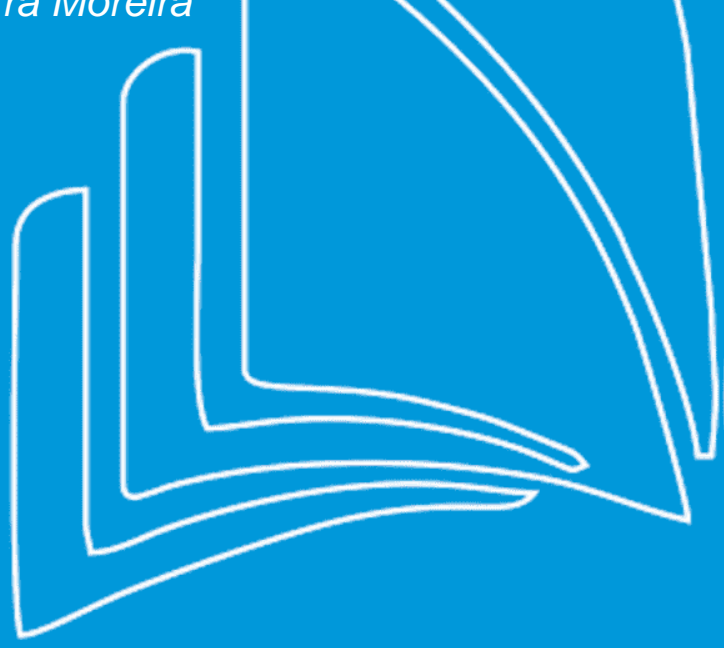

Universidade Federal do Ceará, Sobral-CE

Universidade Federal do Geará, Sobral-CE
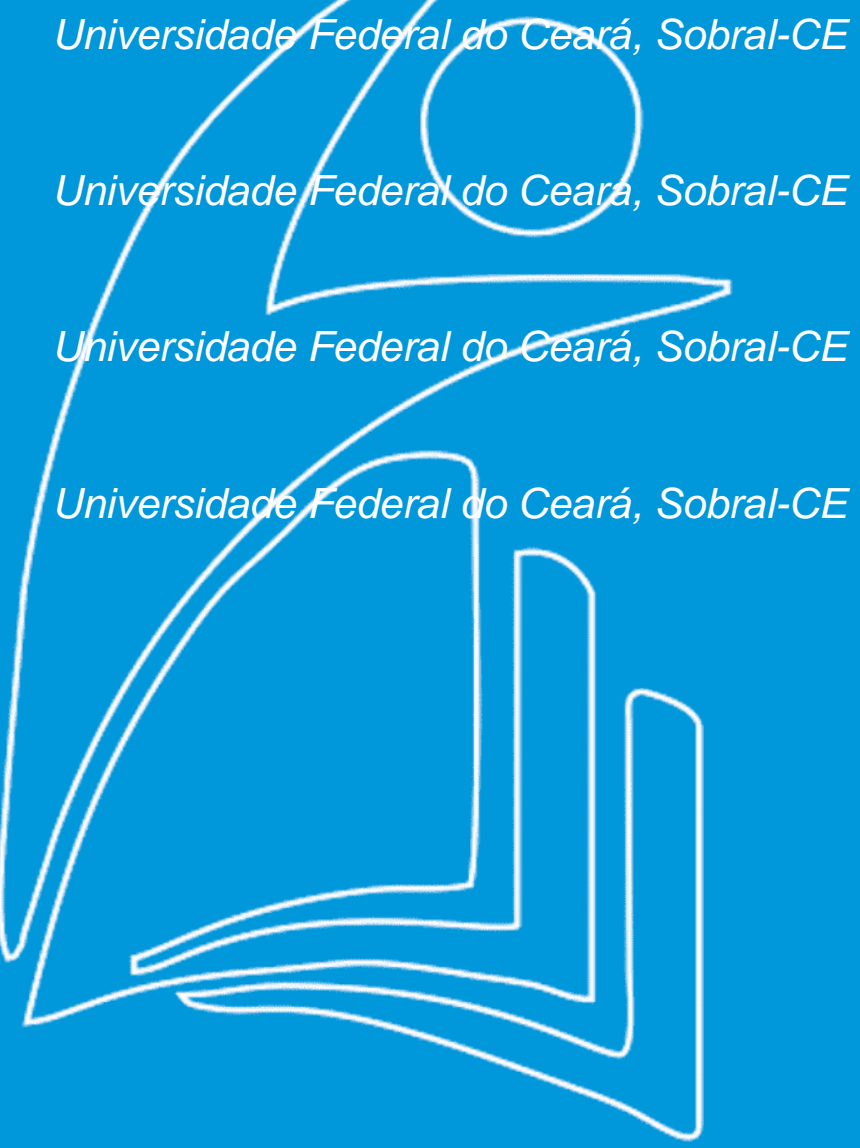
Resumo: Este artigo investiga um sistema de geração de energia eólica com o gerador síncrono de imãs permanentes (GSIP) incorporado a um algoritmo de compensação de corrente harmônica. $O$ comportamento do sistema é analisado para variação de potência gerada e sob velocidade variável. 0 controle das potências é realizado no conversor do lado do gerador (CLG) em coordenadas dq utilizando o controlador PI convencional e, no conversor do lado da rede (CLR) em coordenadas $\alpha \beta$ com o controlador P-Multiressonante. O GSIP é conectado a um conversor CA/CC e, por meio de um elo CC é conectado à rede elétrica através de um conversor CC/CA. No ponto de acoplamento comum (PAC) é conectado uma carga não-linear que demanda uma corrente não-senoidal da rede elétrica. Um filtro ativo paralelo (FAP) a partir do CLR é implementado para mitigar as componentes harmônicas da rede elétrica e melhorar a qualidade de energia. Os resultados obtidos mostram que a técnica aplicada no controle das potências ativa e reativa, e na filtragem ativa pelo CLR foram satisfatórios para o fornecimento de energia na rede elétrica.

Palavras-chaves: CLG; CLR; compensação harmônica; controle de potências; GSIP; FAP. 


\section{INTRODUÇÃO}

A energia eólica tem se destacado como uma das tecnologias de energia renovável mais limpas do mundo. No futuro usinas eólicas desempenharão um papel importante na geração de eletricidade, pois ajudarão na redução da emissão de gases poluentes associadas às tecnologias tradicionais de geração (Singh, 2016). O GSIP é um dos geradores elétricos mais eficiente em sistemas de velocidade variável devido a vantagens como: reduzido custo de manutenção, maior confiabilidade e longevidade devido a ausência de caixa multiplicadora (Beainy et al., 2016).

A qualidade da energia elétrica em uma rede de distribuição está vinculada, principalmente, à fonte geradora e aos tipos de carga (Agrawal et al., 2018). Estas, quando não-lineares, resultam em formas de ondas de tensão e corrente distorcidas no sistema elétrico, em virtude da adição de componentes harmônicos nas frequências múltiplas da componente fundamental (Souza et al., 2016). Como consequência, são observados a diminuição do fator de potência, afundamentos e flutuações de tensão na rede elétrica (Moreira et al., 2019). Para reduzir estes problemas de qualidade de energia, são utilizados filtros de potência para mitigar as harmônicas da rede elétrica.

Em sistemas de energia, os filtros ativos de potência têm sido extensamente aplicado para melhoria da qualidade de energia. Essa solução analisa o sinal de corrente e tensão da carga e, com base em metodologias de controle, realiza a filtragem gerando correntes de compensação que são injetadas na rede elétrica de modo a cancelar as harmônicas indesejáveis (Schwanz et al.,2016). Para este cancelamento ocorrer, estratégias de controle são propostas por diversos trabalhos. Em (Balamurugan e Nithya, 2017) é proposto um algoritmo de controle do filtro baseado na teoria das potências instantâneas que gera uma corrente de referência para mitigar harmônicos, já em (Moftah et al.,2016) o filtro ativo proposto tem o controle baseado na teoria synchrounous reference frame (SRF).

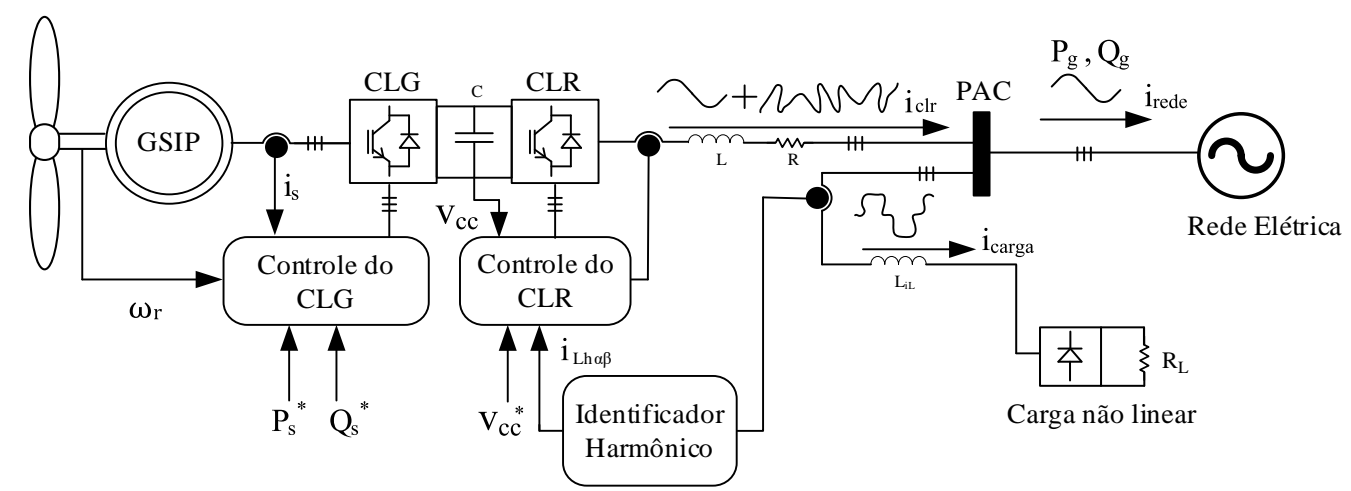

Fig. 1 Esquemático de operação do GSIP/FAP 
Neste artigo é apresentado um sistema de geração de energia eólica com mitigação das componentes harmônicas utilizando filtro ativos paralelos (FAP). A melhoria da qualidade de energia é realizada através do controle do conversor do lado da rede (CLR), que realiza a compensação harmônica da corrente da rede elétrica, utilizando o controlador P-Multiressonante, no ponto de acoplamento comum (PAC) da rede elétrica na presença de uma carga não linear. Este controlador, P-Multiressonte, apresenta resposta eficiente na presença de diferentes dinâmicas de cargas como demonstrado em (Bairagi et al.,2019) e, quando comparado ao PI convencional, este controlador pode rastrear uma referência senoidal com erro zero no estado estacionário, além de garantir maior capacidade de rejeição às perturbações (Husev et al., 2020). A Fig. 1 mostra o esquema proposto nesta pesquisa e a análise é realizada em dois casos. No caso $A$, é realizado a análise do comportamento do sistema quando a velocidade é variada. Já no caso $B$, além do comportamento da geração é verificado também a função de filtragem harmônica.

\section{CONTROLE DAS POTÊNCIAS DO GERADOR SÍNCRONO DE ÍMÃS PERMANENTES}

O controle dos conversores do lado do gerador e do lado da rede foram feitos em coordenadas dq e $\alpha \beta$, respectivamente. Ambos foram projetados utilizando o método de resposta em frequência com margem de fase de 60 e margem de ganho acima de $10 \mathrm{~dB}$ (OGATA, 2010).

\subsection{CONTROLE DO CONVERSOR DO LADO DO GERADOR (CLG)}

Para controlar de forma isolada as potências ativas e reativas do GSIP, foi utilizada a estratégia por orientação de fluxo do rotor, em que a referência síncrona foi orientada ao longo do eixo d (Arminaser Yazdani, 2010). Desta forma, tem-se o desacoplamento das potências ativa e reativa. O modelo matemático do gerador em coordenadas dq é representado por (1) e (2).

$$
\begin{gathered}
V_{s d}=R_{s} i_{s d}+L_{s d} \frac{d i_{s d}}{d t}-L_{s q} \omega_{r} i_{s q} \\
V_{s q}=R_{s} i_{s q}+L_{s q} \frac{d i_{s q}}{d t}+L_{s d} \omega_{r} i_{s d}+\omega_{r} \lambda_{m}
\end{gathered}
$$

em que $V_{s d}$ e $V_{s q}$ são as componentes da tensão no estator, $R_{s}$ a resistência de armadura, $i_{s d}$ e $i_{s q}$ são as correntes de excitação, $L_{s d}$ e $L_{s q}$ representam as indutâncias do estator em dq, $\omega_{r}$ a velocidade do rotor e $\lambda_{m}$ o fluxo magnético. A equação do torque eletromagnético no rotor é representada por (3).

$$
T_{e}=\left(\frac{3}{2}\right)\left(\frac{p}{2}\right)\left[\left(L_{d}-L_{q}\right) i_{q} i_{d}-\lambda_{m} i_{q}\right]
$$


em que $T_{e}$ é o torque eletromagnético e $p$ é o número de polos do GSIP. O valor de $T_{e}$ depende da construção do gerador elétrico, que pode ser de polos lisos ou salientes. O gerador utilizado no projeto é de polos lisos, logo, $L_{d}=L_{q}$. As variáveis $u_{d}$ e $u_{q}$ foram introduzidas a partir de (1) e (2).

$$
\begin{gathered}
u_{d}=V_{s d}+\omega_{r} L_{s q} i_{s q} \\
u_{q}=V_{s d}-\omega_{r} L_{s d} i_{s q}-\omega_{r} \lambda_{m}
\end{gathered}
$$

Desta forma, (1) e (2) representam o desacoplamento com sistema de primeira ordem, do inglês single-input-single-output (SISO), para que as componentes da corrente do estator sejam reguladas a partir de (4) e (5). Substituindo as variáveis introduzidas em (4) e (5), tem-se como resultado (6) e (7).

$$
\begin{aligned}
& L_{s d} \frac{d i_{s d}}{d t}+R_{s} i_{s d}=u_{d} \\
& L_{s q} \frac{d i_{s q}}{d t}+R_{s} i_{s q}=u_{q}
\end{aligned}
$$

Logo, as componentes $i_{s d}$ e $i_{s q}$ podem ser controladas, respectivamente, a partir de suas referências $i_{s d}{ }^{*}$ e $i_{s q}{ }^{*}$ (Fig. 2).

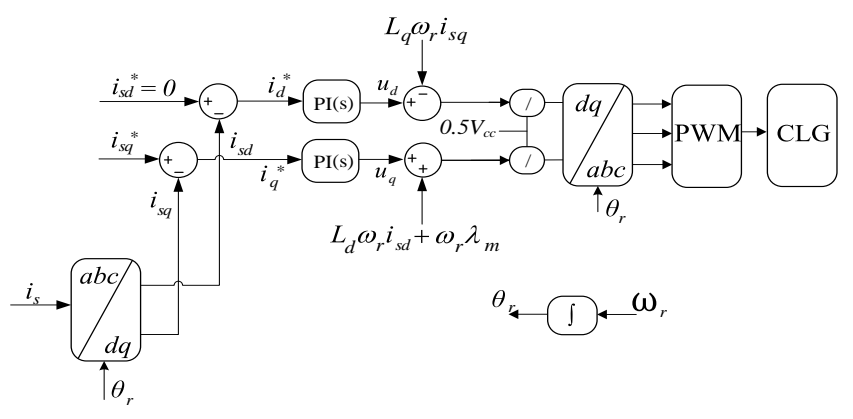

Fig. 2 Esquema de controle do conversor do lado do gerador (CLG).

As potências ativa e reativa do GSIP são definidas por (8) e (9).

$$
\begin{aligned}
& P_{s}=\frac{3}{2}\left(V_{s d} i_{s d}+V_{s q} i_{s q}\right) \\
& Q_{s}=\frac{3}{2}\left(V_{s q} i_{s d}+V_{s d} i_{s q}\right)
\end{aligned}
$$

Na malha de controle do CLG foi utilizado o controlador PI com ganho proporcional de 22,0634 e integral de 39.313 para frequência de cruzamento de ganho $w_{c}=3.000 \mathrm{rad} / \mathrm{s}$ e margem de fase de $M F_{d}=60^{\circ}$.

\subsection{Controle do conversor do lado da rede (CLR)}

Na modelagem utilizada para o CLR, a geração de sinal das correntes elétricas de referência $i_{\alpha}{ }^{*}$ e $i_{\beta}{ }^{*}$ em coordenadas $\alpha \beta$ é proveniente da malha do controlador de tensão do barramento $\mathrm{CC}$, como mostra a Fig. 3. As entradas da malha do controlador são as tensões no PAC em coordenadas $\alpha \beta$ e as 
potências ativa e reativa de referência. Foi utilizado controlador PI com ganho proporcional de 0,0961 e integral de 1,4713 . No projeto de controle do CLR o controlador utilizado foi o P-Multiressonante nas harmônicas 5aㅡ, 7aㅡ, 11aㅡ e 13aㅡ ordens, em que a sua função de transferência $C(s)$ é dada por (10) conforme Nascimento Filho (2014).

$$
C(s)=k_{p}+\frac{k_{p}}{T_{r}} \sum_{h=5,7,11,13} \frac{s}{s^{2}+(h \omega)^{2}}
$$

$k_{p}$ e $T_{r}$ são os parâmetros de projeto do controlador, sendo os valores obtidos de 149,9047 e 0,0079, respectivamente para frequência de cruzamento de ganho $w_{c}=15.000 \mathrm{rad} / \mathrm{s}$ e margem de fase de $M F_{d}=60^{\circ}$.

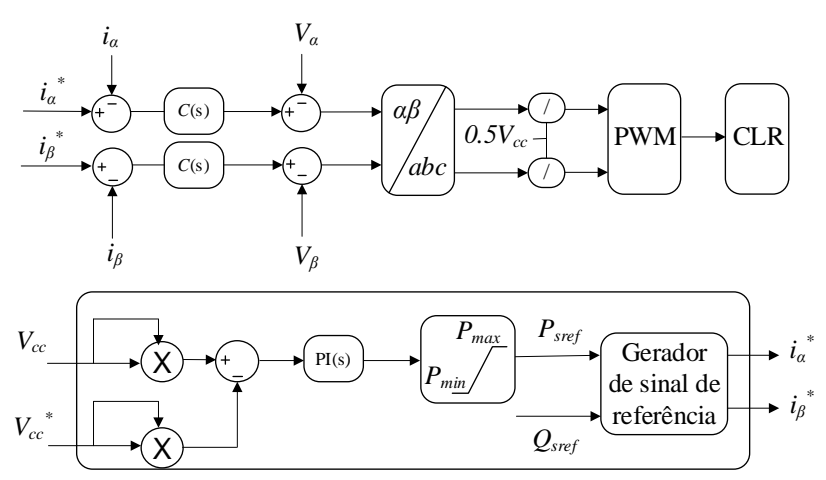

Fig. 3 Esquema de controle do conversor do lado da rede (CLR).

As potências ativa e reativa em coordenadas $\alpha \beta$ são dadas por (11) e (12).

$$
\begin{gathered}
P_{\text {ref }}=\frac{3}{2}\left[V_{\alpha} i_{\alpha}+V_{\beta} i_{\beta}\right] \\
Q_{\text {ref }}=\frac{3}{2}\left[-V_{\alpha} i_{\beta}+V_{\beta} i_{\alpha}\right]
\end{gathered}
$$

nde $V_{\alpha}$ e $V_{\beta}$ são as componentes da tensão elétrica em coordenadas $\alpha \beta$, que não são controláveis e $i_{\alpha}$ e $i_{\beta}$ são as componentes da corrente elétrica, que são controladas para proporcionar o controle das potências de referência $P_{\text {ref }}$ e $Q_{r e f}$. As referências das componentes de corrente elétrica $i_{\alpha}{ }^{*} e i_{\beta}{ }^{*}$ são calculadas a partir de (13) e (14)

$$
\begin{aligned}
i_{\alpha}{ }^{*} & =\frac{2}{3} \frac{V_{\alpha}}{\left(V_{\alpha}^{2}+V_{\beta}^{2}\right)} P_{r e f}+\frac{2}{3} \frac{V_{\beta}}{\left(V_{\alpha}^{2}+V_{\beta}^{2}\right)} Q_{r e f} \\
i_{\beta}{ }^{*} & =\frac{2}{3} \frac{V_{\beta}}{\left(V_{\alpha}^{2}+V_{\beta}^{2}\right)} P_{r e f}-\frac{2}{3} \frac{V_{\alpha}}{\left(V_{\alpha}^{2}+V_{\beta}^{2}\right)} Q_{r e f} .
\end{aligned}
$$

Assim, infere-se que, a partir de (13) e (14), $P_{\text {ref }}$ e $Q_{\text {ref }}$ podem controladas de forma independente. 


\section{FILTRO ATIVO PARALELO NO CONVERSOR DO LADO DA REDE}

O CLR funciona com a função de FAP para mitigar as componentes harmônicas presentes na rede elétrica. Para a implementação do FAP, foram incluidas as correntes $i_{L h \alpha}$ e $i_{L h \beta}$ nas malhas de $i_{\alpha}$ e $i_{\beta}$, respectivamente, como mostra a Fig. 4. As correntes $i_{L h \alpha}$ e $i_{L h \beta}$ representam as componentes harmônicas da carga não linear defasadas em 180․ Esta mudança permite a mitigação das harmônicas de corrente na rede elétrica e mantém a tensão elétrica no elo CC.

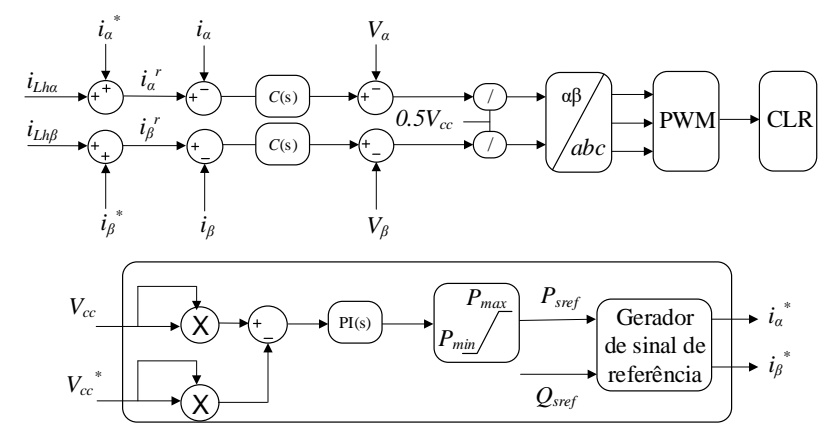

Fig. 4 Esquemático do CLR com função de filtro ativo paralelo.

As novas correntes de referência $i_{\alpha}^{r}$ e $i_{\beta}^{r}$ são definidas em (15) e (16), respectivamente.

$$
\begin{aligned}
& i_{\alpha}^{r}=i_{\text {Lh } \alpha}+i_{\alpha}{ }^{*} \\
& i_{\beta}^{r}=i_{L h \beta}+i_{\beta}{ }^{*}
\end{aligned}
$$

As correntes $i_{L d}$ e $i_{L q}$ são as componentes de corrente da carga não linear em coordenadas dq, que passam por filtros passa baixas cuja saídas são as componentes fundamentais da corrente da carga não linear em coordenadas $d q, i_{L f d}$ e $i_{L f q}$, e as componentes harmônicas da corrente da carga $i_{L h d}$ e $i_{L h q}$, são representadas por (17) e (18).

$$
\begin{aligned}
& i_{L h d}=i_{L d}-i_{L f d} \\
& i_{L h q}=i_{L q}-i_{L f q}
\end{aligned}
$$

As componentes harmônicas da corrente da carga $i_{\text {Lhd }}$ e $i_{\text {Lhq }}$ foram filtradas em dq a partir de um identificador harmônico devido a facilidade de filtragem nessas coordenadas, conforme Fig. 5 e, em seguida, foram transformadas para as coordenadas $\alpha \beta$.

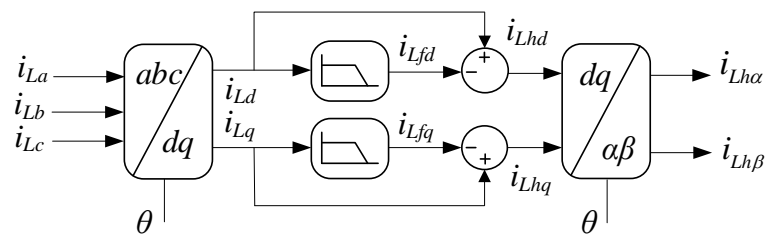

Fig. 5 Identificador harmônico de corrente elétrica em coordenadas $\alpha 6$. 
A verificação do conteúdo harmônico da rede elétrica é feita a partir do cálculo da distorção harmônica total (DHT) por (19):

$$
\operatorname{DHT}(\%)=100 \frac{\sqrt{\sum_{h=2}^{50} I_{h}^{2}}}{I_{1}}
$$

em que $I_{h}$ é a h-ésima componente harmônica da corrente da rede elétrica e $I_{1}$ é a componente fundamental. As componentes inter-harmônicas são desconsideradas no cálculo da DHT.

\section{RESULTADOS DE SIMULAÇÃO}

A técnica de controle para o sistema geração de energia eólica através do GSIP/FAP é verificada com o software de simulação computacional Matlab/Simulink ${ }^{\circledR}$. A Fig. 1 ilustra o sistema proposto apresentando uma turbina eólica acoplada ao GSIP, dois conversores eletrônicos, conhecido como back-to-back, a rede elétrica e um retificador trifásico alimentando a carga não linear. A análise será realizada por meio da variação da corrente de armadura do GSIP, para verificar a potência que será suprida ao PAC e a DHT da corrente na rede elétrica, em dois estudos de caso. Nos conversores é utilizada a modulação em largura de pulsos por sinais senoidais (SPWM) e uma frequência de chaveamento de $15 \mathrm{kHz}$.

Tabela 1. Parâmetros utilizados na simulação

\begin{tabular}{|c|c|c|}
\hline & Parâmetros & Valores \\
\hline CLR & $\mathrm{R}, \mathrm{L}, \mathrm{C}$ & $\begin{array}{c}5 \Omega, 10 \mathrm{mH} \\
9000 \mu \mathrm{F}\end{array}$ \\
\hline CLG & $\begin{array}{c}R_{s}, L_{s}, \lambda_{m}, P_{n o m}, V_{L L}, f \\
p\end{array}$ & $\begin{array}{c}2,895 \Omega, 8,5 \mathrm{mH}, \\
0,175 \mathrm{~Wb}, 12 \mathrm{~kW}, \\
380 \mathrm{~V}, 60 \mathrm{~Hz}, 8 \\
\text { polos }\end{array}$ \\
\hline Carga & $R_{L 1}, L_{i L}$ & $40 \Omega, 500 \mu \mathrm{H}$ \\
\hline Rede & $V_{L L}, f$ & $380 \mathrm{~V}, 60 \mathrm{~Hz}$ \\
\hline
\end{tabular}

\subsection{CASO A}

Neste caso, o sistema de geração de energia eólica com o GSIP fornece potência nominal e apresenta variação de potência gerada. É incorporado a variação de velocidade para exemplificar o sistema mais próximo do real.

A resposta das potências ativa e reativa entregues ao PAC é mostrada na Fig. 6 . A potência ativa é regulada no valor nominal de $12 \mathrm{~kW}$ e reajustada para $8 \mathrm{~kW}$. A potência reativa é controlada em zero sem compensação de reativo na rede elétrica, mantendo o fator de potência unitário. 
A Fig. 7 mostra a resposta da tensão do elo $\mathrm{CC}\left(\mathrm{V}_{\mathrm{cc}}\right)$ estabelecida pelo controle vetorial do CLR seguindo a referência $\left(V_{c c}{ }^{*}\right)$. A tensão do elo CC é carregada até a tensão de pico de linha da rede elétrica e depois regulada em 800 V. A velocidade do GSIP (Fig. 8) apresenta variações para simular o sistema operando com velocidade variável.

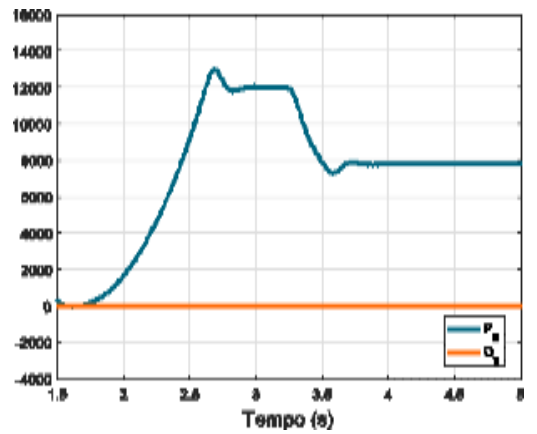

Fig. 6 Potências ativa e reativa entregues ao PAC.

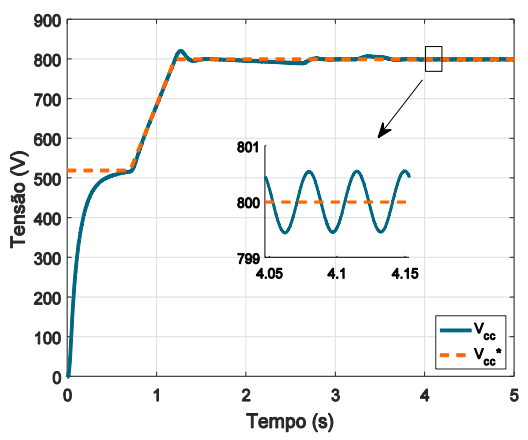

Fig. 7 Controle de tensão do elo CC.

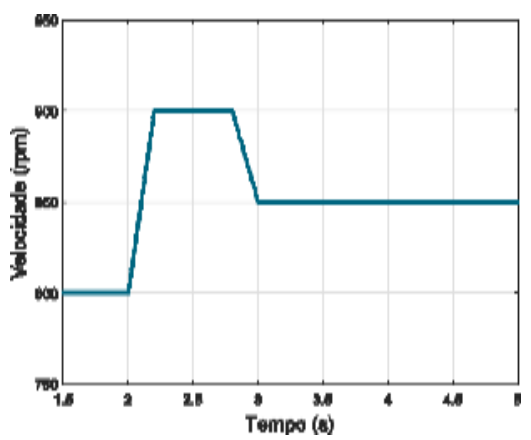

Fig. 8 Velocidade do GSIP.

As formas de ondas das correntes no estator do GSIP em coordenadas dq e na fase A são ilustradas na Fig. 9. A componente $i_{s d}$ é nula e rastreia a referência $i_{s d}{ }^{*}$, assim como a corrente de eixo $\mathrm{q}$, $i_{s q}$, segue a referência $i_{s q}{ }^{*}$. A corrente na fase $\mathrm{A}\left(i_{s a}\right)$ aumenta sua magnitude na mesma proporção em que é variada a corrente $i_{s q}$. As formas de ondas das correntes da rede, da carga, do CLR, e da tensão da 
rede quando o GSIP opera abaixo da potência nominal são verificadas na Fig. 10. O sistema alimenta parcialmente uma carga não-linear de 11,8 kW para uma velocidade de $850 \mathrm{rpm}$.

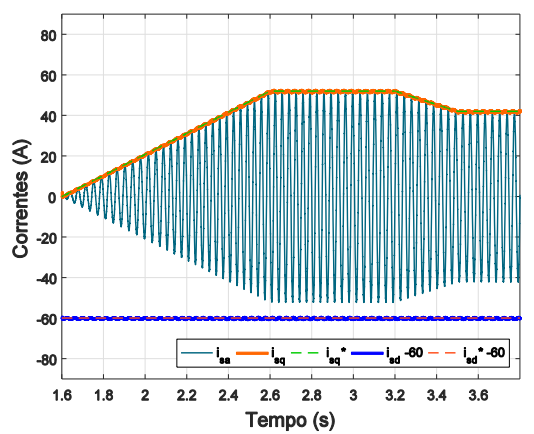

Fig. 9 Formas de ondas das correntes do CLG nas coordenadas dq e na fase A.

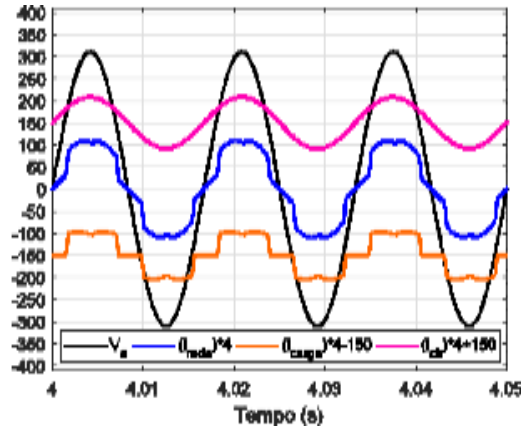

Fig. 10 Formas de ondas da tensão e da corrente da rede elétrica, da corrente da carga e do CLR quando o sistema fornece uma potência de $8 \mathrm{~kW}$ sem filtragem ativa.

O espectro harmônico da corrente da carga não-linear é mostrado na Fig. 11. A distorção harmônica total da corrente $\left(\mathrm{DHT}_{\mathrm{i}}\right)$ da carga é $28,51 \%$. As harmônicas de ordem ímpar $(5,7,11$ e 13$)$ são as principais componentes harmônicas responsáveis por esta distorção.

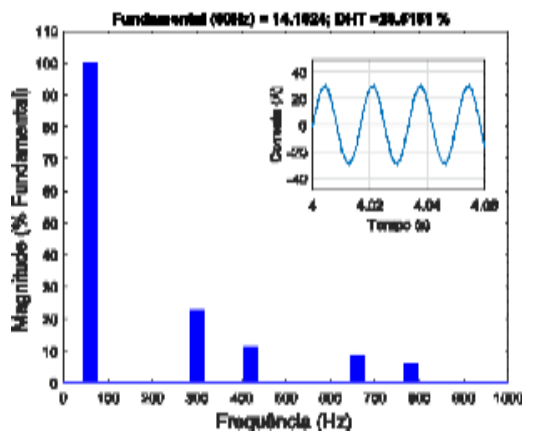

Fig. 11 Espectro harmônico da corrente da carga.

A forma de onda da corrente da rede elétrica é distorcida devido a carga não linear conectada ao PAC. A Fig. 12 mostra o espectro harmônico da corrente da rede quando o sistema entrega potência de 8 kW. A DHT $T_{i}$ da corrente da rede para 8 kW é $14,08 \%$. 


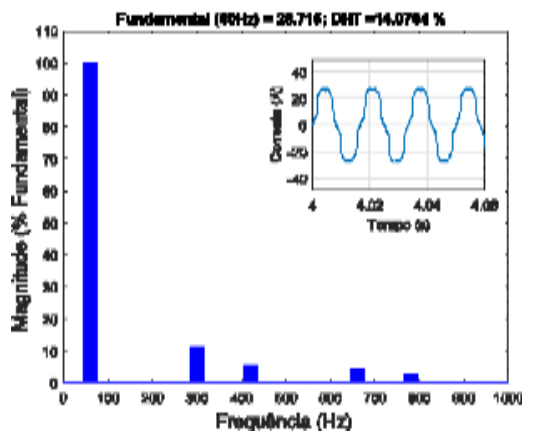

Fig. 12 Espectro harmônico da corrente da rede elétrica quando o sistema fornece 8 kW.

\subsection{CASO B}

Neste caso, é aplicado ao sistema de geração eólica a função de filtro ativo para mitigar as componentes harmônicas da corrente na rede elétrica. A variação da potência gerada e da velocidade do GSIP são realizadas. As Figuras 6 a 9 são as mesmas para ambos os casos, uma vez que o controle vetorial do CLG é o mesmo e a resposta à tensão do elo CC apresenta o mesmo comportamento. A Fig 13 mostra as formas de ondas da tensão e da corrente da rede, do CLR e da carga não-linear quando o sistema opera com mitigação de corrente harmônica para 8 kW. O conteúdo harmônico da corrente da rede para 8 kW com a compensação harmônica de corrente, na Fig 14, apresenta uma DHTide 2,62 $\%$.

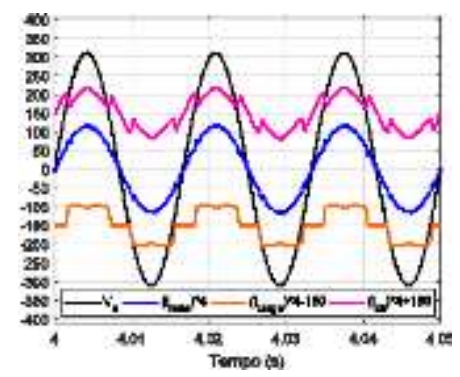

Fig. 13 Formas de ondas da tensão e da corrente da rede elétrica, da corrente da carga e do CLR quando o sistema fornece uma potência de $8 \mathrm{~kW}$ com filtragem ativa.

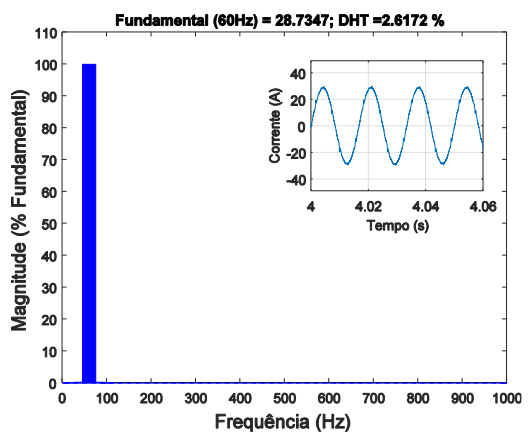

Fig. 14 Espectro harmônico da corrente da rede elétrica quando o sistema fornece 8kW com mitigação de corrente harmônica. 
Na tabela 2 são mostrados os valores de DHTi quando o sistema fornece $8 \mathrm{~kW}$ e potência nominal de $12 \mathrm{~kW}$ sem compensação harmônica e com FAP. Para a potência nominal houve redução da $D H T_{i}$ de 10,66 \% para 1,92 \% com a utilização do filtro e, para $8 \mathrm{~kW}$ a $D H T_{i}$ de 14,08 \% foi para 2,62 \%. Os diferentes valores de $\mathrm{DHT}_{i}$ se justificam pela componente fundamental da corrente ser maior para potências maiores, uma vez que a tensão da rede é fixa. Ao comparar os dois casos estudados verificase a redução da $D H T_{i}$ da corrente da rede elétrica devido a redução das componentes harmônicas ímpares, conforme a tabela 3. Com o FAP no sistema, é possível inferir que estes valores de distorções estão de acordo com os padrões internacionais (IEE, 2014).

Tabela 2. Valores de $\mathrm{DHT}_{\mathrm{i}}$

\begin{tabular}{|c|c|c|}
\hline$P_{S}$ & Caso A (Sem FAP) & Caso B (Com FAP) \\
\hline $8 \mathrm{~kW}$ & $14,0764 \%$ & $2,6172 \%$ \\
\hline $12 \mathrm{~kW}$ & $10,6610 \%$ & $1,9218 \%$ \\
\hline
\end{tabular}

Tabela 3. Porcentagem das harmônicas em relação a componente fundamental.

\begin{tabular}{|c|c|c|c|c|}
\cline { 2 - 5 } \multicolumn{1}{c|}{} & \multicolumn{2}{c|}{$\begin{array}{c}\text { Caso A } \\
(\text { Sem FAP) }\end{array}$} & \multicolumn{2}{c|}{$\begin{array}{c}\text { Caso B } \\
\text { (Com FAP) }\end{array}$} \\
\hline $\mathrm{h} P_{s}$ & $8 \mathrm{~kW}$ & $12 \mathrm{~kW}$ & $8 \mathrm{~kW}$ & $12 \mathrm{~kW}$ \\
\hline $5^{\mathrm{a}}$ & $11,1254 \%$ & $8,4332 \%$ & $0,0131 \%$ & $0,0413 \%$ \\
\hline $7^{\mathrm{a}}$ & $5,4056 \%$ & $4,0963 \%$ & $0,0074 \%$ & $0,0215 \%$ \\
\hline $11^{\mathrm{a}}$ & $4,2898 \%$ & $3,2505 \%$ & $0,0036 \%$ & $0,0089 \%$ \\
\hline $13^{\mathrm{a}}$ & $2,8942 \%$ & $2,1928 \%$ & $0,0025 \%$ & $0,0094 \%$ \\
\hline
\end{tabular}

\section{CONCLUSÕES}

Este artigo investiga o comportamento do GSIP em um sistema de geração de energia eólica sob velocidade variável. Na presença de uma carga não linear conectada ao PAC, é analisada a potência entregue à rede elétrica quando a corrente de excitação do gerador é modificada e, a distorção harmônica da corrente da rede. No caso A é verificado o sistema de geração sem FAP e, no caso B além da geração de energia elétrica é observada a melhoria da qualidade de energia pela utilização de um filtro ativo paralelo no CLR. Comparando os valores de $D H T_{i}$ da corrente da rede obtidos no caso 1 e no caso 2, para a potência nominal de $12 \mathrm{~kW}$ a DHTide 10,66 \% foi para 1,92\% e com 8 kW apresenta DHT de 14,08 \% para 2,62 \%. Desse modo, é possível inferir que as técnicas de controle empregadas juntamente com a mitigação das componentes harmônicas através da filtragem ativa mostraram-se eficazes na geração de energia eólica e na melhoria da qualidade de energia.

\section{AGRADECIMENTOS}

Os autores agradecem a FUNCAP pelo apoio financeiro (processo BP3-0139-00022.01.00/18). 


\section{REFERÊNCIAS}

A. Beainy, C. Maatouk, N. Moubayed and F. Kaddah.(2016). Comparison of different types of generator for wind energy conversion system topologies, 2016 3rd REDEC, Zouk Mosbeh, pp. 1-6.

A. B. Moreira, T. A. D. S. Barros, V. S. D. C. Teixeira, R. R. D. Souza, M. V. D. Paula and E. R. Filho.(2019). Control of Powers for Wind Power Generation and Grid Current Harmonics Filtering From Doubly Fed Induction Generator: Comparison of Two Strategies, in IEEE Access, vol. 7, pp. 32703-32713.

Amirnaser Yazdani, R.I., (2010). Voltage-Source Converters in Power Systems - Modeling, Control, and Applications. WILEY IEEE.

Bairagi, A.K., Sheikh, M.R.I., Habib, M.A. et al. (2019). High-Performance P+Resonant Controller Design for Single-phase Islanded Microgrid. J Control Autom Electr Syst.

D. Schwanz, A. Bagheri, M. Bollen and A. Larsson. (2016) "Active harmonic filters: Control techniques review," 17th International Conference on Harmonics and Quality of Power (ICHQP), Belo Horizonte, pp. 36-41,

IEEE Recommended Practice and Requirements for Harmonic Control in Electric Power Systems Redline, (2014), IEEE Std 519-2014 (Revision of IEEE Std 519-1992 vol., no., pp.1-213.

M. A. M. A. Moftah, G. E. A. Taha and E. A. Ibrahim, (2016). Active power filter for variable-speed wind turbine PMSG interfaced to grid and non-linear load via three phase matrix converter, Eighteenth International Middle East Power Systems Conference, Cairo, no. 3, pp. 1013-1019.

OGATA, K (2010). Engenharia de Controle Moderno - 5a Edição. Prentice-Hall.

O. Husev, C. Roncero-Clemente, E. Makovenko, S. P. Pimentel, D. Vinnikov and J. Martins. (2020) Optimization and Implementation of the Proportional-Resonant Controller for Grid-Connected Inverter With Significant Computation Delay, in IEEE Transactions on Industrial Electronics, vol. 67, no. 2, pp. 1201-1211

P. S. Nascimento Filho, T. A. dos S. Barros, M. G. Villalva and Ernesto Ruppert Filho. (2014). Design methodology of P-res controllers with harmonic compensation for three-phase DC-ac grid-tie inverers with LCL output filter. 2nd IEEE International Conference on Power Electronics.

R. Balamurugan and R. Nithya. (2017). Solar PV Based Shunt Active Filter with p-q Theory Control for Improvement of Power Quality. Journal of Circuits, Systems and Computers.

S. Agrawal, V. K. Gupta, D. K. Palwalia and R. K. Somani. (2018). Power Quality Improvement of Standalone Wind Energy Generation System for Non Linear Load. 2nd ICPEICES, Delhi, India, pp. 374379.

Souza, R. R.; Moreira, Adson B.; Barros, T. A. S.; Nascimento Filho, P. S.; Ruppert, E. (2016). Aplicação de controladores $\mathrm{PI}+$ Ressonante no controle de potências ativa e reativa em geração eólica utilizando GIRB conectado à rede elétrica com tensão distorcida. V Simpósio Brasileiro de Sistemas Elétricos, (SBSE), Natal, RN.

S. Singh.(2016). Wind power: Future lies within. V 7th India International Conference on Power Electronics (IICPE), Patiala, pp. 1-5. 


\section{Capítulo 5}

\section{doi $10.37423 / 211105026$}

\section{ÁLGEBRA DE CLIFFORD APLICADA A ANÁLISE DA POTÊNCIA ELÉTRICA EM SISTEMAS MONOFÁSICOS SOB CONDIÇÕES NÃO SENOIDAIS.}

Rafael Furquim Junior

Niraldo Roberto Ferreira

Fernando Augusto MIOreire

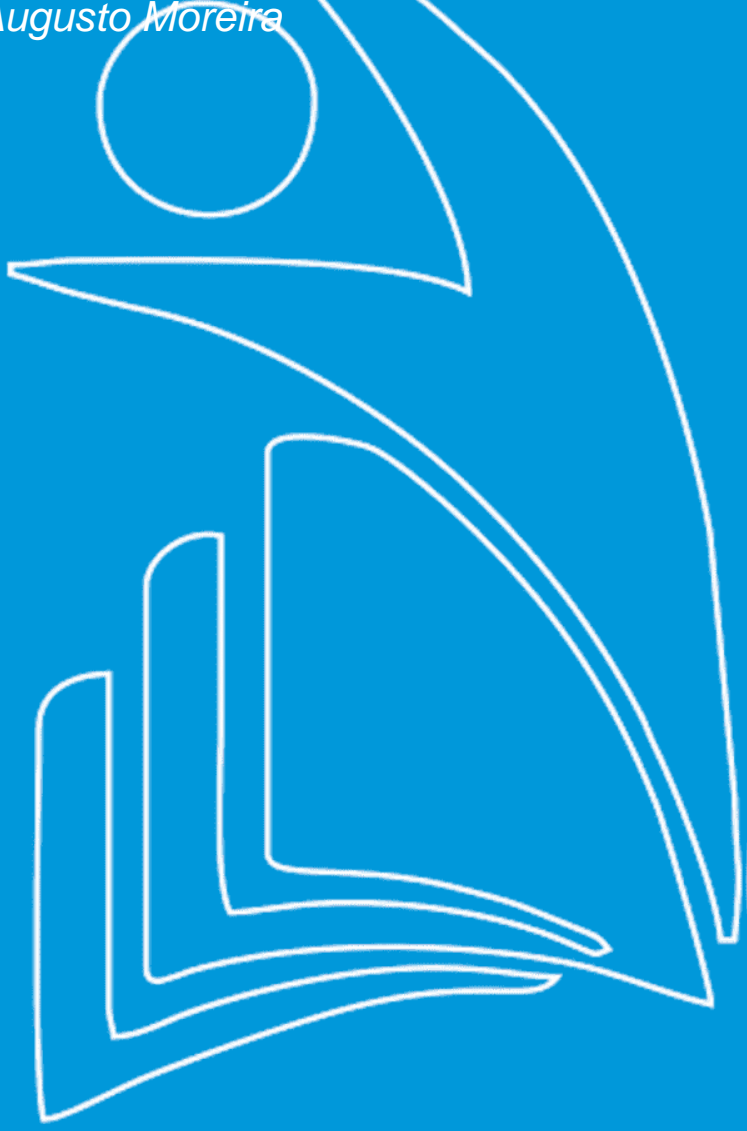

Universidade Federal da Bahia

Universidade Federal da Bahia

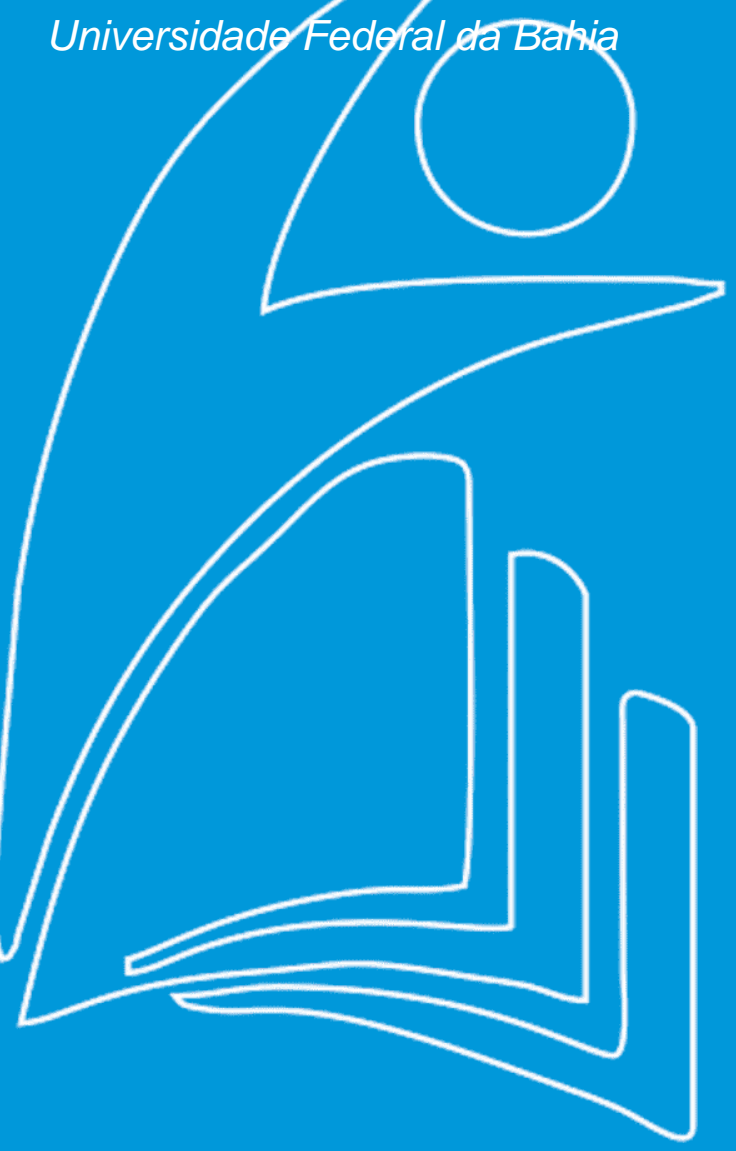


Resumo: A primeira teoria criada para fazer a análise da potência em circuitos elétricos no regime permanente não senoidal foi devida a Budeanu em 1927. Ela se baseia numa extrapolação do método clássico utilizado para o regime puramente senoidal. Por não explicar apropriadamente alguns aspectos do comportamento do fluxo de potências permitiu a proposição de diversas outras teorias. Entre as mais recentes está a proposta de Castro-Núñez, que para modelar adequadamente a potência não ativa e o caráter multivetorial da potência elétrica utiliza uma ferramenta matemática chamada Álgebra de Clifford ou Álgebra Geométrica. Neste artigo apresenta-se uma abordagem modificada da Álgebra Geométrica que se mostra capaz de reproduzir os resultados da análise da potência instantânea no domínio do tempo.

Palavras-chaves: potência aparente; multivetor; álgebra geométrica; potência não ativa; harmônicas. 


\section{INTRODUÇÃO}

A análise de circuitos no regime permanente senoidal tornou- se prática com o uso dos números complexos e dos fasores, sendo proposta por Steinmetz (1897), onde foram definidas as potências ativa $P$, reativa $Q$ e aparente $S$.

A primeira definição de potência no domínio da frequência, aplicada a circuitos monofásicos de corrente alternada em regime periódico não senoidal, foi proposta por Budeanu (1927), na qual foram apresentadas as três parcelas que compõem a potência aparente $S$ : potência ativa $P$, potência reativa QB e potência distorciva DB. Esta teoria é amplamente utilizada na engenharia elétrica.

Logo após Budeanu propor sua teoria no domínio da frequência, Fryze (1932) propôs uma teoria para definição da potência no domínio do tempo. Esta é baseada em decomposição ortogonal, dando origem às componentes de corrente ativa e não ativa.

Contudo, estas teorias foram contestadas por vários pesquisadores e nas décadas de 70 a 90 surgiram outras, destacando-se entre elas as teorias de Shepherd e Zakikhani (1972), Akagi et al. (1983), e Czarnecki (1988). Porém, ainda não há consenso na comunidade científica que aponte uma única teoria para explicar a potência não ativa em regime não senoidal.

Assim sendo, Castro-Núñez (2013) apresentou uma teoria propondo a abordagem da álgebra de Clifford, também conhecida como álgebra geométrica, para a análise da potência em regime permanente não senoidal.

Este trabalho utiliza essa mesma ferramenta para seu desenvolvimento, porém, apresenta uma abordagem mais simples de transformação do domínio do tempo para o domínio da álgebra geométrica de Clifford, propondo pela primeira vez um operador de rotação distinto para cada frequência harmônica.

\subsection{A TEORIA DA POTÊNCIA DE BUDEANU}

Budeanu, em 1927, compreendeu que a potência aparente tinha mais de duas componentes em condições periódicas não senoidais e postulou que a Potência Aparente é composta por duas componentes ortogonais, chamadas de Potência Ativa e Não Ativa. A Potência Ativa sendo definida como a média da potência instantânea no domínio do tempo dada por: 


$$
P=\frac{1}{T} \cdot \int_{0}^{T} p(t) d t=V_{0} \cdot I_{0}+\sum_{\substack{h=1 \\ h, n \in Z^{+}}}^{n} V_{h} \cdot I_{h} \cdot \cos \varphi_{h}
$$

Onde $V_{0}$ e $I_{0}$ representam a componente contínua da tensão e corrente, $V_{h}$ e $I_{h}$ as componentes harmônicas, $n$ o número de harmônicos e $h$ o índice harmônico. $Z^{+}$é o conjunto dos números inteiros positivos.

A Potência Não Ativa é dividida em duas componentes definidas como Potência Reativa de Budeanu $Q B$ e Potência de Distorção $D_{B}$. A Potência Reativa de Budeanu é calculada pela soma das potências reativas individuais de cada ordem harmônica, ou seja:

$$
Q_{B}=\sum_{h=1}^{n} V_{h} \cdot I_{h} \cdot \operatorname{sen} \varphi_{h}
$$

E a Potência de Distorção é dada por:

$$
D_{B}=\sqrt{S^{2}-P^{2}-Q_{B}^{2}}
$$

\subsection{LIMITAÇÕES DA TEORIA DE BUDEANU}

As duas principais limitações da teoria de Budeanu, conforme apontado nos trabalhos de Shepherd e Zakikhani (1972), e também Czarnecki (1988) são:

A redução da potência reativa, no valor de $Q B$, não reduz o valor eficaz da corrente de alimentação para o valor de corrente ativa, como ocorre no caso senoidal; A potência de distorção DB pode, ou não, ter algo em comum com a distorção das formas de onda da tensão e corrente.

Estas limitações na potência reativa de Budeanu podem ter motivado a exclusão deste conceito da norma IEEE 1459 em sua revisão de 2010.

\subsection{POTÊNCIA EM REGIME NÃO SENOIDAL NO DOMÍNIO DO TEMPO.}

Em um circuito com tensões e correntes em diferentes frequências, originam-se potências em diferentes frequências, incluindo-se as associadas as frequências cruzadas, sendo então a potência, 
multivetorial. Assim sendo, para se encontrar a potência aparente total em regime não senoidal, utiliza-se da definição de Fourier, apresentada abaixo sucintamente.

Dado um sinal $x(t)$ periódico não senoidal como abaixo:

$$
x(t)=\sum_{h=1}^{n}\left[\sqrt{2} \cdot A_{h} \cdot \operatorname{sen}(h w t+\alpha)\right]
$$

A norma ou magnitude de $x(t)$ será:

$$
\|x(t)\|=\sqrt{\frac{1}{T} \int_{\frac{-T}{2}}^{\frac{T}{2}} x^{2}(t) d t}=\sqrt{\sum_{h=1}^{n} A_{h}^{2}}
$$

valor eficaz da componente de ordem harmônica $h$, T é o período da onda fundamental.

Sendo $x(t)$ o sinal de tensão $v(t)$, sua norma ou magnitude será:

$$
\|v(t)\|=\sqrt{\sum_{h=1}^{n} V_{h}^{2}}=\sqrt{V_{1}^{2}+V_{2}^{2}+\ldots . V_{n}^{2}}
$$

A potência aparente instantânea no domínio do tempo é definida como:

$$
S(t)=v(t) \cdot i(t)
$$

A norma ou magnitude da potência aparente é definida como:

$$
\|S(t)\|=\|v(t)\| \cdot\|i(t)\|
$$

Substituindo-se as normas de tensão e corrente se obtém:

$$
\|S(t)\|=\sqrt{V_{1}^{2}+V_{2}^{2}+\ldots . V_{n}^{2}} \cdot \sqrt{I_{1}^{2}+I_{2}^{2}+\ldots . I_{n}^{2}}
$$

Rearranjando algebricamente se obtém:

$$
\|S(t)\|=\sqrt{\left(V_{1}^{2}+V_{2}^{2}+\ldots . V_{n}^{2}\right) \cdot\left(I_{1}^{2}+I_{2}^{2}+\ldots . I_{n}{ }^{2}\right)}
$$


Simplificando-se a apresentação da norma ou magnitude da potência aparente, se obtém

$$
\|S(t)\|=\sqrt{S_{11}{ }^{2}+S_{12}{ }^{2}+\ldots \ldots . S_{m n}^{2}}
$$

onde: $\mathrm{S}_{\mathrm{ij}}=\left(\mathrm{V}_{\mathrm{i}}\right)^{2} \cdot\left(\mathrm{I}_{\mathrm{j}}\right)^{2}$

\section{2. ÁLGEBRA DE CLIFFORD}

A álgebra de Clifford, também conhecida como álgebra geométrica, é uma ferramenta matemática capaz de manipular escalares, vetores e objetos geométricos de forma relativamente simples. Portanto, tem encontrado aplicação em vários ramos da física e da engenharia.

Neste trabalho, a álgebra de Clifford será utilizada para a análise da potência em sistemas elétricos monofásicos sob condição periódica não senoidal.

\subsection{DEFINIÇÕES BÁSICAS DA ÁLGEBRA GEOMÉTRICA DE CLIFFORD}

Um entendimento em profundidade é apresentado em Jancewicz (1988), neste trabalho apresenta-se apenas o conteúdo essencial. A base da álgebra geométrica, segundo Chappell et al. (2014), é estender o espaço vetorial euclidiano $\mathbf{R}$ com uma operação de multiplicação, associativa e anticomutativa, designada produto geométrico dando origem a um espaço vetorial expandido $\mathbf{C l}(\mathbf{R n})$, sendo fechado para a soma e multiplicação de vetores.

Considerando-se a base ortonormal $\{\boldsymbol{\sigma} 1, \boldsymbol{\sigma} \mathbf{2}\}$ do espaço vetorial euclidiano $\mathrm{R} 2$ e dois vetores quaisquer V e W deste espaço, sendo:

$$
\begin{aligned}
& \boldsymbol{V}=v_{1} \sigma_{1}+v_{2} \sigma_{2} \\
& \boldsymbol{W}=w_{1} \sigma_{1}+w_{2} \sigma_{2}
\end{aligned}
$$

onde: $\sigma_{1}, \sigma_{2}$ são vetores unitários ortogonais de $R^{2}$ e $v_{1} \sigma_{1}, v_{2} \sigma_{2}, w_{1} \sigma_{1}, w_{2} \sigma_{2}$ são vetores de $R^{2}$

Obtém-se o espaço vetorial expandido $C l\left(R^{2}\right)$, aplicando-se o produto geométrico de Clifford entre $\boldsymbol{V}$ e $\boldsymbol{W}$, abaixo definido:

$$
\begin{aligned}
\boldsymbol{V} \boldsymbol{W} & =\boldsymbol{V} \cdot \boldsymbol{W}+\boldsymbol{V} \boldsymbol{\Lambda} \boldsymbol{W} \\
\boldsymbol{V} \boldsymbol{W} & =\left(v_{1} \sigma_{1}+v_{2} \sigma_{2}\right)\left(w_{1} \sigma_{1}+w_{2} \sigma_{2}\right) \\
& =v_{1} w_{1} \sigma_{1}{ }^{2}+v_{1} w_{2} \sigma_{1} \sigma_{2}+v_{2} w_{1} \sigma_{2} \sigma_{1}+v_{2} w_{2} \sigma_{2}{ }^{2}
\end{aligned}
$$


onde: $\boldsymbol{V} \cdot \boldsymbol{W}$ é o produto interno, um escalar, e corresponde ao produto interno euclidiano e $\boldsymbol{V} \wedge \boldsymbol{W}$ é o produto externo, um novo tipo de elemento chamado bivetor do espaço $\mathbf{C l}\left(\boldsymbol{R}^{2}\right)$.

O produto geométrico (2.1.4) é agrupado utilizando-se do axioma da álgebra de Clifford apresentado abaixo:

$$
\sigma_{i} \sigma_{j}=\left\{\begin{array}{ll}
1 & \Leftrightarrow i=j \rightarrow \sigma_{1}{ }^{2}=\sigma_{2}{ }^{2}=1 \\
-\sigma_{j} \sigma_{i} & \Leftrightarrow i \neq j \rightarrow \sigma_{1} \sigma_{2}=-\sigma_{2} \sigma_{1}
\end{array}\right\}
$$

Do qual origina-se o elemento $\sigma i \sigma j$, anticomutativo, chamado bivetor, o qual tem magnitude, direção e sentido, como um segmento de área orientado, abaixo exemplificado na Fig.1
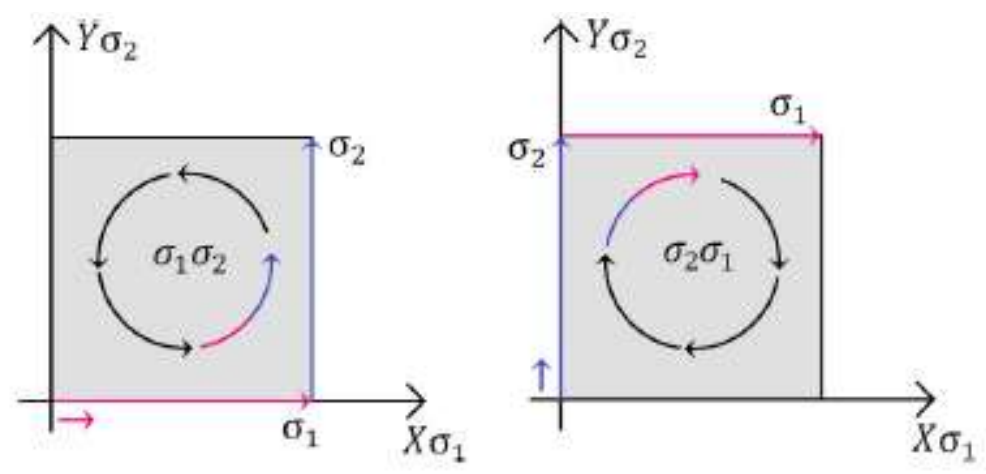

Fig. 1 Unidade bivetora em Castro-Núñez (2013).

Aplicando-se o axioma (2.1.5) ao produto geométrico (2.1.4) obtém-se no domínio geométrico de Clifford $\mathrm{Cl}\left(\boldsymbol{R}^{2}\right)$ :

$$
\boldsymbol{V} \boldsymbol{W}=\left(v_{1} w_{1}+v_{2} w_{2}\right)+\left(v_{1} w_{2}-v_{2} w_{1}\right) \sigma_{1} \sigma_{2}
$$

Portanto, um escalar, que corresponde ao produto interno e um bivetor, que corresponde ao produto externo.

O produto externo da álgebra geométrica estende o conceito de número imaginário para um sistema de n-dimensões.

Conforme Hestenes e Sobczyk (1984), a propriedade de contração, apresentada abaixo, é que diferencia a álgebra geométrica de Clifford de outras álgebras associativas, ao definir que o quadrado de vetores não nulos seja positivo.

$$
a^{2}=a a=a \cdot a=\|a\|^{2}
$$


Assim sendo, a propriedade acima proporciona uma medida de comprimento de vetores, no espaço vetorial de Clifford $\boldsymbol{C l}\left(\boldsymbol{R}^{\mathbf{2}}\right)$ que é a mesma do espaço vetorial euclidiano $\boldsymbol{R}^{\mathbf{2}}$. Seja o vetor $\boldsymbol{a}=a 1 \boldsymbol{\sigma} \mathbf{1}+a \mathbf{2} \boldsymbol{\sigma}$, um vetor qualquer de $\boldsymbol{R}^{2}$, aplicando-se (2.1.7) e (2.1.5) obtém-se a norma no domínio de Clifford:

$$
\begin{aligned}
& \boldsymbol{a}^{2}=a_{1}^{2} \sigma_{1}^{2}+a_{1} a_{2} \sigma_{1} \sigma_{2}+a_{2} a_{1} \sigma_{2} \sigma_{1}+a_{2}^{2} \sigma_{2}^{2}=a_{1}^{2}+a_{2}^{2} \\
& \boldsymbol{a}^{2}=\|\boldsymbol{a}\|^{2}=>\|\boldsymbol{a}\|^{2}=a_{1}^{2}+a_{2}^{2}=>\|\boldsymbol{a}\|=\sqrt{a_{1}^{2}+a_{2}^{2}}
\end{aligned}
$$

\subsection{A ÁLGEBRA DE CLIFFORD E AS FREQUÊNCIAS HARMÔNICAS}

A transformação proposta por Steinmetz (1897) para o domínio da frequência, não se aplica a circuitos com sinais $n$ - senoidais, pois a informação da frequência angular é perdida. Abaixo se vê dois sinais distintos no domínio do tempo que são representados pelo mesmo número complexo.

$$
\begin{aligned}
& v(t)=100 \sqrt{2} \cos \left(w t-90^{\circ}\right) \rightarrow V_{1}=100 e^{-j 90}=-j 100 \\
& v(t)=100 \sqrt{2} \cos \left(3 w t-90^{\circ}\right) \rightarrow V_{3}=100 e^{-j 90}=-j 100
\end{aligned}
$$

Buscando preencher a ligação entre os domínios do tempo e da frequência, alguns pesquisadores, como Castro-Núñez (2013) e Castilla et al. (2008) utilizaram a álgebra geométrica de Clifford, por ter as bases necessárias para representar sinais periódicos não senoidais.

As transformações propostas em Castro-Núñez e Castro-Puche (2012), se apresentam como um produto das bases do sistema, em função da ordem harmônica n, conforme equações abaixo:

$$
\left.\left.\begin{array}{l}
x_{c}(t)=\sqrt{2} \cos (w t) \leftrightarrow \sigma_{1} \\
x_{s}(t)=\sqrt{2} \sin (w t) \leftrightarrow-\sigma_{2}
\end{array}\right\} \begin{array}{l}
x_{c n}(t)=\sqrt{2} \cos (n w t) \leftrightarrow \sigma_{c n}=\Lambda_{i=2}^{n-1} \sigma_{i} \\
x_{s n}(t)=\sqrt{2} \sin (n w t) \leftrightarrow \sigma_{s n}=\Lambda_{i=1, i \neq 2}^{n+1} \sigma_{i}
\end{array}\right\}
$$

Observa-se que a natureza dos elementos propostos para a frequência fundamental em (2.2.2) tratamse de vetores, e ainda que, a transformação de seno foi definida como o negativo da base $\sigma 2$. Enquanto a natureza dos elementos propostos em (2.2.3), um bivetor para a segunda harmônica, onde $n=2$, e um trivetor para a terceira harmônica, onde $n=3$, sendo estes, incoerentes com o domínio do tempo. 
No domínio do tempo, os sinais de excitação senoidais, são sempre representados por vetores, diferenciando-se apenas a velocidade angular entre a frequência fundamental e suas respectivas harmônicas, bem como, o módulo dos vetores.

Apresenta-se, neste trabalho, outra forma de representar as componentes, de tensão ou corrente, senoidais de frequência fundamental e frequências harmônicas no domínio da álgebra geométrica. Bem como, propõem-se pela primeira vez, um operador de rotação distinto para cada frequência, o qual estende o conceito de número complexo para n-dimensões. As transformações propostas são:

$$
\begin{aligned}
& x_{c}(t)=\sqrt{2} \cos (n w t) \leftrightarrow \sigma_{(2 n-1)} \\
& x_{s}(t)=\sqrt{2} \sin (n w t) \leftrightarrow-\sigma_{(2 n)}
\end{aligned}
$$

as quais mostram-se equivalentes, inclusive para a frequência fundamental com $n=1$, eliminando-se a necessidade de duas definições para cada função, como proposto por Castro- Núñez e Castro-Puche (2012) em (2.2.2) e (2.2.3). onde: $x_{-}(t)$ = sinal cosseno ou seno, de tensão ou corrente, na frequência $(\mathrm{n} \omega), \sigma_{(2 \mathrm{n}-1)} \rightarrow$ sinal cosseno no domínio da álgebra geométrica, de tensão ou corrente, na frequência $(n \omega)$, e $\sigma_{(2 n)}-$ sinal seno no domínio da álgebra geométrica, de tensão ou corrente, na frequência $(n \omega)$.

Além disso, com as transformações propostas neste trabalho, a natureza dos sinais de excitação senoidais no domínio de Clifford são sempre vetores, portanto, em conformidade com o domínio do tempo.

As funções cosseno e seno na frequência fundamental do domínio do tempo são mapeadas para o domínio geométrico como vetores $x \boldsymbol{\sigma} \boldsymbol{1}$ e y $\sigma \mathbf{2}$, respectivamente. Assim sendo, o produto dos vetores acima por $\boldsymbol{\sigma} \mathbf{1 \sigma 2}$ produz uma defasagem (rotação) de $90^{\circ}$ no domínio geométrico de Clifford.

Neste trabalho propõem-se um operador de rotação $\sigma(2 n-1)(2 n)$, para cada frequência $(n \omega)$, abaixo definido e utilizando-se da propriedade acima descrita:

$$
\sigma_{(2 n-1)} \Lambda \sigma_{(2 n)}=\sigma_{(2 n-1)(2 n)}
$$

A transformação e o operador de rotação propostos neste trabalho, estendem a transformação proposta por Steinmetz (1897) para o regime periódico não senoidal, utilizando-se das propriedades da álgebra geométrica e de um sistema multivetorial. Dando-se origem a um sistema, no domínio de 
Clifford, totalmente coerente com as operações em regime não senoidal, no domínio do tempo.

Apresentam-se, como exemplo, na Fig. 2 abaixo, as transformações e os operadores de rotação para as frequências fundamental $n=1$, e segunda harmônica $n=2$.
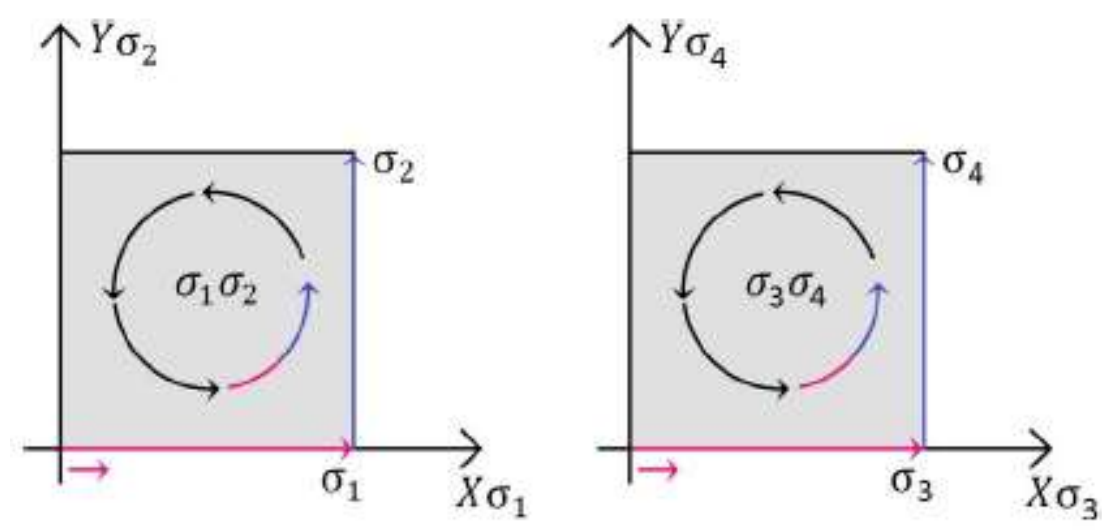

Fig. 2 Sistema multivetorial, adaptado de Castro-Núñez (2013).

Uma consequência da álgebra de Clifford é que utilizando-se do axioma (2.1.5) o quadrado de bivetores, como $\sigma \mathbf{1} \sigma \mathbf{2}$, resultam em -1 , tal como $(\sigma \sigma)^{2}=\sigma \sigma \sigma \sigma=-\sigma \sigma \sigma \sigma=-\sigma \sigma=-(\sigma 1)^{2}=-1$, o que é coerente com a definição da unidade imaginária j dos números complexos, tal que $\mathrm{j}^{2}=(\sigma 1 \sigma 2)^{2}=-1$. Assim sendo, pode-se reescrever as expressões para as reatâncias indutiva e capacitiva do domínio complexo para o domínio da álgebra geométrica, obtendo-se:

$$
\boldsymbol{X}_{\mathrm{L}}=\mathrm{wL} \sigma_{1} \sigma_{2} \quad \boldsymbol{X}_{\mathrm{C}}=\frac{-\sigma_{1} \sigma_{2}}{\mathrm{wC}}
$$

Contudo, neste trabalho propomos a introdução de um operador de rotação (2.2.6) para cada frequência, portanto, as reatâncias indutiva e capacitiva ficam assim definidas:

$$
X_{L}=w L \sigma_{(2 n-1)} \sigma_{(2 n)} \quad X_{C}=\frac{-\sigma_{(2 n-1)} \sigma_{(2 n)}}{w C}
$$

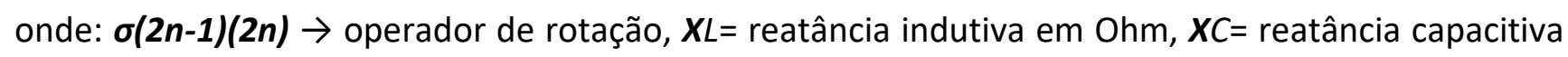
em Ohm, $n$ é a ordem da frequência harmônica sendo considerada.

\subsection{POTÊNCIA COMO PRODUTO GEOMÉTRICO E MULTIVETOR.}

A equação da potência no domínio de Clifford é definida como um multivetor $\boldsymbol{M}$. O multivetor potência como em Castro-Núñez et al. (2019) pode conter um escalar, um vetor, um bivetor, por exemplo: 4, 
$\sigma 1, \sigma 1 \sigma 2, \sigma 5 \sigma 6$, dependendo apenas dos sinais seno ou cosseno e da ordem da maior frequência harmônica presente no circuito.

As equações que definem o multivetor potência são apresentadas abaixo:

$$
M=V I=V \cdot I+V \Lambda I
$$

onde: $\boldsymbol{M}=$ potência no domínio de Clifford em VA, $\boldsymbol{V}=$ vetor de tensão no domínio de Clifford, e $\boldsymbol{I}=$ vetor de corrente no domínio de Clifford.

A aplicação dos produtos interno e externo da álgebra geométrica, resulta em produtos escalares e produtos de ordem k, os quais são agrupados da forma:

$$
\boldsymbol{M}=\sum_{\mathrm{k}=0}^{\mathrm{n}}\langle\rangle_{\mathrm{k}}
$$

Onde $k=0$ representa um escalar (potência ativa), $k=1$ um vetor, $k=2$ um bivetor e assim sucessivamente, então o multivetor será:

$$
\boldsymbol{M}=\langle\rangle_{0}+\langle\rangle_{1}+\langle\rangle_{2}+\ldots \ldots \ldots\langle\rangle_{\mathrm{n}}
$$

O reverso de um multivetor $M$ é indicado conforme apresentado abaixo:

$$
\boldsymbol{M}^{\dagger}=\sum_{\mathrm{k}}(-1)^{\frac{\mathrm{k}(\mathrm{k}-1)}{2}} \cdot\langle\boldsymbol{M}\rangle_{\mathrm{k}}
$$

O reverso do multivetor permite encontrar a norma do multivetor que é definida por:

$$
\|\boldsymbol{M}\|=\sqrt{\left\langle\boldsymbol{M} \cdot \boldsymbol{M}^{\dagger}\right\rangle_{0}}
$$

onde: $\left\langle\boldsymbol{M} \cdot \boldsymbol{M}^{\dagger}\right\rangle_{0}$ representa a parte escalar do multivetor de potência $\mathbf{M}$.

No entanto, como este trabalho estende a proposta de Steinmetz (1897) para o domínio de Clifford, faz-se necessário utilizar-se do conceito de conjugado, pois, caso contrário, não haveria compatibilidade com a convenção de sinais para as potências capacitiva e indutiva, exatamente como ocorre com a transformação do domínio do tempo para o domínio da frequência. Portanto: 


$$
M=V I^{*}=V \cdot I^{*}+V \Lambda I^{*}
$$

\section{APLICAÇÃO DA ÁLGEBRA DE CLIFFORD}

Nesta seção será utilizado o circuito da Fig. 3 abaixo, Castro- Núñez e Castro-Puche (2012), para desenvolvimento das soluções no domínio do tempo e no domínio de Clifford.

O objetivo deste exemplo é mostrar uma aplicação utilizando a metodologia proposta neste trabalho para o domínio de Clifford e evidenciar que conduz ao mesmo resultado obtido no domínio do tempo.

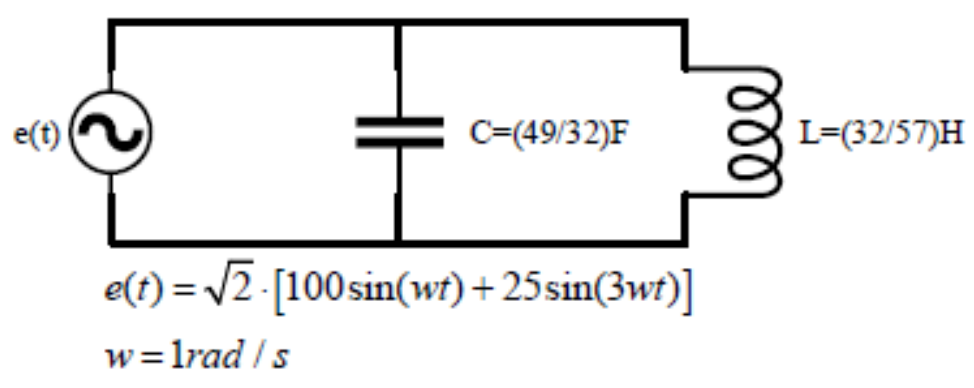

Fig. 3 Circuito usado para demonstrar as análises nos domínios do tempo e da frequência.

\subsection{RESOLUÇÃO NO DOMÍNIO DO TEMPO}

Em função das unidades utilizadas serem as unidades padrão do SI, elas serão omitidas ao longo deste trabalho.

Realizando-se os cálculos no domínio do tempo, para cada sinal de excitação do circuito da Fig. 3, na frequência fundamental obtém-se os seguintes resultados para as correntes (valores máximos):

$$
\begin{aligned}
& I_{C}(w t)=\frac{4900 \sqrt{2} \cdot \sin \left(w t+90^{\circ}\right)}{32} \\
& I_{L}(w t)=\frac{5700 \sqrt{2} \cdot \sin \left(w t-90^{\circ}\right)}{32}
\end{aligned}
$$

Considerando-se que as correntes no capacitor e no indutor estão defasadas de 180, isto possibilita a simples soma algébrica entre estas correntes, dando como resultado uma única parcela, que será capacitiva ou indutiva, em função do módulo de cada componente. Na frequência fundamental o módulo de IL é maior, logo a resultante da corrente é indutiva.

Os cálculos para o terceiro harmônico produzem: 


$$
\begin{aligned}
& I_{C}(3 w t)=\frac{3675 \sqrt{2} \cdot \sin \left(3 w t+90^{\circ}\right)}{32} \\
& I_{L}(3 w t)=\frac{1425 \sqrt{2} \cdot \sin \left(3 w t-90^{\circ}\right)}{96}
\end{aligned}
$$

onde: $I C(k t)=$ corrente no capacitor na frequência $(\omega)$ ou $(3 \omega)$, e $I L(k t)=$ corrente no indutor na frequência $(\omega)$ ou $(3 \omega)$.

Fazendo-se a mesma consideração acima, verifica-se que para a frequência de $3 \omega$ o módulo da corrente capacitiva IC é maior que a indutiva, logo a resultante da corrente é capacitiva.

Abaixo apresentam-se as correntes resultantes na carga para as tensões nas frequências fundamental e terceiro harmônico, respectivamente:

$$
\begin{aligned}
& I_{(w t)}=25 \sqrt{2} \cdot \sin \left(w t-90^{\circ}\right) \\
& I_{(3 w t)}=100 \sqrt{2} \cdot \sin \left(3 w t+90^{\circ}\right)
\end{aligned}
$$

Para o cálculo da potência instantânea no domínio do tempo $S(t)$, realiza-se o produto entre tensões e correntes abaixo indicado:

$$
S_{(t)}=\left\{\begin{array}{l}
\sqrt{2}[100 \sin (w t)+25 \sin (3 w t)] . \\
{\left[25 \sqrt{2} \cdot \sin \left(w t-90^{\circ}\right)+100 \sqrt{2} \cdot \sin \left(3 w t+90^{\circ}\right)\right]}
\end{array}\right\}
$$

Realizando-se os produtos de tensões e correntes acima, utilizando-se das propriedades trigonométricas seno(a+b) e seno(a-b), encontram-se as potências instantâneas fornecidas pelas fontes. No domínio do tempo se obtém:

$$
\begin{aligned}
& S(t)=P+S_{11}(t)+S_{13}(t)+S_{31}(t)+S_{33}(t) \\
& S_{11}(t)=-2500 \cdot[2 \sin (w t) \cos (w t)] \\
& S_{13}(t)=10^{4} \cdot[2 \sin (w t) \cos (3 w t)] \\
& S_{31}(t)=-625 \cdot[2 \sin (3 w t) \cos (w t)] \\
& S_{33}(t)=2500 \cdot[2 \sin (3 w t) \cos (3 w t)]
\end{aligned}
$$


onde: $P=O W$ e $\operatorname{Sij}(t)=$ produto entre tensão e corrente nas frequências $(\omega)$ e $(3 \omega)$.

Aplicando-se (1.3.8) aos resultados das potências instantâneas eficazes obtidas em (3.1.9), calcula-se:

$$
S=\sqrt{(-2500)^{2}+\left(10^{4}\right)^{2}+(-625)^{2}+2500^{2}}=10625 \mathrm{VA}
$$

Aplicando-se (1.3.8) apenas às parcelas $S_{11}$ e $S_{33}$ que correspondem a energia reativa $Q$ nas frequências fundamental e terceiro harmônico, calcula-se:

$$
Q=\sqrt{(-2500)^{2}+2500^{2}}=3535,53 V A r
$$

Aplicando-se (1.3.8) apenas às parcelas $S_{13}$ e $S_{31}$ que correspondem a energia distorciva $D$ nas frequências cruzadas, calcula-se:

$$
D=\sqrt{\left(10^{4}\right)^{2}+(-625)^{2}}=10019,51 V A r
$$

Portanto, fica evidente a capacidade de análise de sistemas monofásicos não senoidais no domínio do tempo.

\subsubsection{RESOLUÇÃO COM O MÉTODO DE BUDEANU.}

A Potência Reativa de Budeanu é calculada pela soma das potências reativas individuais de cada ordem harmônica, conforme (1.1.2). No circuito apresentado anteriormente, as potências calculadas em Castro-Núñez e Castro-Puche (2012), apresentaram os resultados: potência reativa na frequência fundamental $Q=$ j2500 VAr e potência reativa no terceiro harmônico é $Q=-j 2500$ VAr.

Assim sendo, aplicando-se (1.1.2) às potências reativas acima, obtém-se QB $=0$ VAr.

O que está incoerente, pois as potências são de frequências distintas e não se compensam neste circuito como previsto pela teoria de Budeanu.

\subsection{RESOLUÇÃO NO DOMÍNIO DA ÁLGEBRA DE CLIFFORD.}

Aplicando-se a transformação proposta (2.2.5) aos sinais de tensão no domínio do tempo do circuito da Fig. 3, obtém-se os sinais de tensão no domínio de Clifford, resultando em: 


$$
\begin{aligned}
& \sin (n w t) \Leftrightarrow-\sigma_{(2 n)} \rightarrow n=1 \rightarrow-\sigma_{2}, n=3 \rightarrow-\sigma_{6} \\
& v_{1}(t)=100 \sqrt{2} \sin (w t) \rightarrow V_{1}=-100 \sigma_{2} \\
& v_{3}(t)=25 \sqrt{2} \sin (3 w t) \rightarrow V_{3}=-25 \sigma_{6}
\end{aligned}
$$

Considerando-se que, com o operador de rotação proposto neste trabalho, as reatâncias indutiva e capacitiva foram definidas em (2.2.8) como:

$$
\boldsymbol{X}_{L}=w L \sigma_{(2 n-1)} \sigma_{(2 n)} \quad \boldsymbol{X}_{C}=\frac{-\sigma_{(2 n-1)} \sigma_{(2 n)}}{w C}
$$

Levando-se em consideração os sinais de frequência com $n=1$ e $n=3$ obtém-se os operadores de rotação das reatâncias:

$$
n=1 \rightarrow \sigma_{1} \sigma_{2} \quad n=3 \rightarrow \sigma_{5} \sigma_{6}
$$

Realizando-se os cálculos no domínio de Clifford, com as definições acima, para a frequência $\omega=1 \mathrm{rad} / \mathrm{s}$ obtém-se as seguintes correntes no capacitor e no indutor:

$$
\begin{aligned}
& \boldsymbol{I}_{\mathrm{C}(\mathrm{w})}=\frac{-100 \sigma_{2}}{\frac{-\sigma_{1} \sigma_{2}}{1 \cdot \frac{49}{32}}}=\frac{-4900 \sigma_{2}}{-32 \sigma_{1} \sigma_{2}} \cdot \frac{\sigma_{1} \sigma_{2}}{\sigma_{1} \sigma_{2}}=\frac{4900 \sigma_{1}}{32} \\
& \boldsymbol{I}_{\mathrm{L}(\mathrm{w})}=\frac{-100 \sigma_{2}}{1 \cdot \frac{32 \sigma_{1} \sigma_{2}}{57}}=\frac{-5700 \sigma_{2}}{32 \sigma_{1} \sigma_{2}} \cdot \frac{-\sigma_{1} \sigma_{2}}{-\sigma_{1} \sigma_{2}}=\frac{-5700 \sigma_{1}}{32}
\end{aligned}
$$

Como as correntes no indutor e no capacitor estão em fases opostas para a mesma frequência, é possível a soma algébrica de seus módulos no domínio de Clifford, obtendo-se:

$$
\boldsymbol{I}_{(\mathrm{w})}=\boldsymbol{I}_{\mathrm{C}(\mathrm{w})}+\boldsymbol{I}_{\mathrm{L}(\mathrm{w})}=-25 \sigma_{1}
$$

Realizando-se os cálculos no domínio de Clifford, com as definições acima, para a frequência $\omega=3 \mathrm{rad} / \mathrm{s}$ obtém-se as seguintes correntes no capacitor e no indutor: 


$$
\begin{aligned}
& \boldsymbol{I}_{C(3 w)}=\frac{-25 \sigma_{6}}{\frac{-\sigma_{5} \sigma_{6}}{3 \cdot \frac{49}{32}}=\frac{-3675 \sigma_{6}}{-32 \sigma_{5} \sigma_{6}} \cdot \frac{\sigma_{5} \sigma_{6}}{\sigma_{5} \sigma_{6}}=\frac{3675 \sigma_{5}}{32}} \\
& \boldsymbol{I}_{L(3 w)}=\frac{-25 \sigma_{6}}{3 \cdot \frac{32 \sigma_{5} \sigma_{6}}{57}}=\frac{-475 \sigma_{6}}{32 \sigma_{5} \sigma_{6}} \cdot \frac{-\sigma_{5} \sigma_{6}}{-\sigma_{5} \sigma_{6}}=\frac{-475 \sigma_{5}}{32}
\end{aligned}
$$

Como as correntes no indutor e no capacitor estão em fases opostas para a mesma frequência, é possível a soma algébrica de seus módulos no domínio de Clifford, obtendo-se:

$$
\boldsymbol{I}_{(3 w)}=\boldsymbol{I}_{C(3 w)}+\boldsymbol{I}_{L(3 w)}=100 \sigma_{5}
$$

A corrente total da carga do circuito obtém-se com a soma de (3.2.6) e (3.2.9) resultando em:

$$
\boldsymbol{I}_{s}=-25 \sigma_{1}+100 \sigma_{5}
$$

Levando-se em consideração que com a metodologia proposta para o operador de rotação, o número imaginário se estende para circuitos n-senoidais, a corrente do circuito também apresentará um valor conjugado, resultando em:

$$
\boldsymbol{I}_{s}^{*}=+25 \sigma_{1}-100 \sigma_{5}
$$

Aplicando-se (2.3.6), nas tensões em (3.2.1) e na corrente conjugada em (3.2.11), calculam-se as parcelas de potências no domínio de Clifford fornecidas pelas fontes do circuito.

No entanto, designando-se a potência como S (e não M) por ser usual na engenharia elétrica.

$$
\begin{aligned}
& \boldsymbol{S}=\boldsymbol{V} \boldsymbol{I}_{s}^{*} \\
& \boldsymbol{S}=\left(-100 \sigma_{2}-25 \sigma_{6}\right) \cdot\left(+25 \sigma_{1}-100 \sigma_{5}\right) \\
& \boldsymbol{S}=-2500 \sigma_{2} \sigma_{1}+10^{4} \sigma_{2} \sigma_{5}-625 \sigma_{6} \sigma_{1}+2500 \sigma_{6} \sigma_{5}
\end{aligned}
$$

Observa-se que este resultado é exatamente o mesmo obtido no domínio do tempo, diferindo apenas no fato de que apresenta valores eficazes e não máximos. A interpretação dos resultados em (3.2.13), com a transformação proposta, é imediata, considerando-se que $\cos (n \omega t) \rightarrow \sigma(2 n-1)$ e que $\operatorname{sen}(n \omega$ t) $\rightarrow \sigma(2 n)$ então, para n=1 obtém-se $\sigma 1$ e $\sigma 2$ e para $n=3$ obtém-se $\sigma 5$ e $\sigma 6$ respectivamente. 
Logo, obtém-se uma correspondência direta e exata com o domínio do tempo, conforme verifica-se em (3.1.9) reescrito abaixo:

$$
\begin{aligned}
& S_{11}(t)=-2500 \cdot[2 \sin (w t) \cos (w t)] \rightarrow \sigma_{2} \sigma_{1} \\
& S_{13}(t)=10^{4} \cdot[2 \sin (w t) \cos (3 w t)] \rightarrow \sigma_{2} \sigma_{5} \\
& S_{31}(t)=-625 \cdot[2 \sin (3 w t) \cos (w t)] \rightarrow \sigma_{6} \sigma_{1} \\
& S_{33}(t)=2500 \cdot[2 \sin (3 w t) \cos (3 w t)] \rightarrow \sigma_{6} \sigma_{5}
\end{aligned}
$$

Concluindo-se a análise de potência aparente, aplica-se (2.3.4) a cada parcela do multivetor (3.2.13), calculando-se o reverso do multivetor potência:

$$
S_{21}^{\dagger}=(-1)^{\frac{2(2-1)}{2}} \cdot\left[\left\langle-2500 \sigma_{2} \sigma_{1}\right\rangle_{2}\right]=+2500 \sigma_{2} \sigma_{1}
$$

onde: $\mathrm{k}=2$ dado que as parcelas são bivetores.

Assim sendo, como as quatro parcelas do multivetor correspondem a bivetores, haverá a inversão de sinal em todas as parcelas, obtendo-se:

$$
\boldsymbol{S}^{\dagger}=+2500 \sigma_{2} \sigma_{1}-10^{4} \sigma_{2} \sigma_{5}+625 \sigma_{6} \sigma_{1}-2500 \sigma_{6} \sigma_{5}
$$

Para se calcular a norma do multivetor aplica-se (2.3.5) aos resultados (3.2.13) e (3.2.15), obtendo-se:

$$
\begin{aligned}
& \|\boldsymbol{S}\|=\sqrt{\left\langle\boldsymbol{S} \cdot \boldsymbol{S}^{\dagger}\right\rangle_{0}} \\
& S=\sqrt{\left\langle\begin{array}{l}
\left(-2500 \sigma_{2} \sigma_{1}+10^{4} \sigma_{2} \sigma_{5}-625 \sigma_{6} \sigma_{1}+2500 \sigma_{6} \sigma_{5}\right) \cdot \\
\left(2500 \sigma_{2} \sigma_{1}-10^{4} \sigma_{2} \sigma_{5}+625 \sigma_{6} \sigma_{1}-2500 \sigma_{6} \sigma_{5}\right)
\end{array}\right\rangle_{0}}
\end{aligned}
$$

Levando-se em consideração que na equação acima interessa- nos apenas a parte escalar da multiplicação, a equação se reduz ao apresentado abaixo:

$$
S=\sqrt{2500^{2}+\left(10^{4}\right)^{2}+625^{2}+2500^{2}}=10625 \mathrm{VA}
$$

resultado idêntico ao domínio do tempo, para a potência aparente total na fonte.

Analisando-se no domínio de Clifford, aplica-se (2.3.5) e calcula-se a norma de $Q$ com os valores de potência reativa em (3.2.13), obtendo-se: 


$$
\begin{aligned}
& \|Q\|=\sqrt{\left\langle\boldsymbol{Q} \cdot \boldsymbol{Q}^{\dagger}\right\rangle_{0}}=\sqrt{\left\langle\begin{array}{l}
\left(-2500 \sigma_{2} \sigma_{1}+2500 \sigma_{6} \sigma_{5}\right) \cdot \\
\left(+2500 \sigma_{2} \sigma_{1}-2500 \sigma_{6} \sigma_{5}\right)
\end{array}\right\rangle_{0}} \\
& Q=\sqrt{2500^{2}+2500^{2}}=3535,53 \mathrm{VAr}
\end{aligned}
$$

Levando-se em consideração que a base do sistema é ortonormal, portanto, os valores estão em quadratura e que a potência ativa é nula $(R=0 \Omega)$, aplica-se (1.1.3) e calcula-se a potência de distorção D:

$$
\begin{aligned}
& D=\sqrt{S^{2}-P^{2}-Q^{2}}=\sqrt{10625^{2}-0^{2}-3535,53^{2}} \\
& D=10019,51 V A r
\end{aligned}
$$

Analisando-se no domínio de Clifford, aplica-se (2.3.5) e calcula-se a norma de $D$ com os valores de potências cruzadas em (3.2.13), obtendo-se:

$$
\begin{aligned}
& \|\boldsymbol{D}\|=\sqrt{\left\langle\boldsymbol{D} \cdot \boldsymbol{D}^{\dagger}\right\rangle_{0}}=\sqrt{\left\langle\begin{array}{l}
\left(10^{4} \sigma_{2} \sigma_{5}-625 \sigma_{6} \sigma_{1}\right) \cdot \\
\left.\left(-10^{4} \sigma_{2} \sigma_{5}+625 \sigma_{6} \sigma_{1}\right)\right\rangle_{0}
\end{array}\right.} \\
& D=\sqrt{\left(10^{4}\right)^{2}+625^{2}}=10019,51 \mathrm{VAr}
\end{aligned}
$$

O que está de acordo com a consideração das potências em quadratura em (3.2.19). Portanto, fica evidente que os valores de potência no domínio do tempo são encontrados no domínio de Clifford, utilizando-se da transformação e operador de rotação propostos.

Verifica-se que os resultados obtidos em Castro-Núñez e Castro-Puche (2012), no domínio de Clifford, divergem dos resultados encontrados no domínio do tempo, os quais são a base de comparação para qualquer sistema, abaixo apresentasse a Tabela 1 sintetizando os resultados. 
Tabela 1. Análise da Potência - Estudo de caso

\begin{tabular}{|c|c|c|c|}
\hline \multicolumn{3}{|c|}{$\begin{array}{l}\text { Resultados obtidos } \\
\text { neste artigo }\end{array}$} & $\begin{array}{c}\text { Castro-Núñez } \\
\text { (2012) }\end{array}$ \\
\hline $\begin{array}{c}\text { Termos } \\
\text { de } \\
\text { Potência }\end{array}$ & $\begin{array}{l}\text { Domínio } \\
\text { do } \\
\text { tempo }\end{array}$ & $\begin{array}{l}\text { Domínio } \\
\text { de } \\
\text { Clifford }\end{array}$ & $\begin{array}{l}\text { Domínio } \\
\text { de } \\
\text { Clifford }\end{array}$ \\
\hline $\mathrm{S}_{11}$ & $-2500 \cdot\left[\begin{array}{l}2 \sin (w t) \\
\cos (w t)\end{array}\right]$ & $-2500 \sigma_{2} \sigma_{1}$ & $*$ \\
\hline $\mathrm{S}_{13}$ & $10^{4} \cdot\left[\begin{array}{l}2 \sin (w t) \cdot \\
\cos (3 w t)\end{array}\right]$ & $10^{4} \sigma_{2} \sigma_{5}$ & $*$ \\
\hline $\mathrm{S}_{31}$ & $-625 \cdot\left[\begin{array}{l}2 \sin (3 w t) \\
\cos (w t)\end{array}\right]$ & $-625 \sigma_{6} \sigma_{1}$ & $*$ \\
\hline \multirow[t]{3}{*}{$\mathrm{S}_{33}$} & $2500 \cdot\left[\begin{array}{l}2 \sin (3 w t) \\
\cos (3 w t)\end{array}\right]$ & $2500 \sigma_{6} \sigma_{5}$ & $*$ \\
\hline & $\begin{array}{l}S(t)=P \\
+S_{11}(t) \\
+S_{13}(t) \\
+S_{31}(t) \\
+S_{33}(t)\end{array}$ & $\begin{array}{l}S= \\
-2500 \sigma_{2} \sigma_{1} \\
+10^{4} \sigma_{2} \sigma_{5} \\
-625 \sigma_{6} \sigma_{1} \\
+2500 \sigma_{6} \sigma_{5}\end{array}$ & $\begin{array}{l}\boldsymbol{M}_{S}= \\
-5000 \sigma_{1} \sigma_{2} \\
-10625 \sigma_{3} \sigma_{4}\end{array}$ \\
\hline & 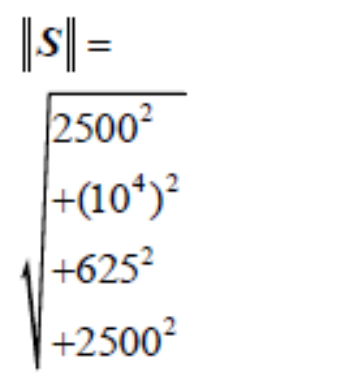 & $\begin{array}{l}\|S\|= \\
\sqrt{\begin{array}{l}2500^{2} \\
+\left(10^{4}\right)^{2} \\
+625^{2} \\
+2500^{2}\end{array}}\end{array}$ & $\begin{array}{l}\left\|\boldsymbol{M}_{S}\right\|= \\
\sqrt{\begin{array}{l}5000^{2} \\
+10625^{2}\end{array}}\end{array}$ \\
\hline $\mathrm{S}(\mathrm{VA})$ & 10625 & 10625 & 11742,7 \\
\hline
\end{tabular}

onde: * indica não apresentado em Castro-Núñez e Castro-Puche (2012) e P=0W. 
Embora, não apresentado em detalhes em Castro-Núñez e Castro-Puche (2012), é possível verificar-se que no multivetor MS as parcelas S11 e S33 foram consideradas como sendo de mesma natureza, pois, com as transformações propostas no referido trabalho, ambas parcelas resultam em $\sigma 1 \sigma 2$ e, portanto, foram adicionadas algebricamente resultando em $-5000 \sigma 1 \sigma 2$. Assim como, as parcelas S13 e S31 também foram consideradas como sendo de mesma natureza, pois, com as transformações propostas no referido trabalho, ambas parcelas resultam em $\sigma 3 \sigma 4$ e, portanto, foram adicionadas algebricamente resultando em $-10625 \sigma 3 \sigma 4$.

Neste trabalho calcula-se em (3.2.12) a potência total no domínio de Clifford S=VI*s, fornecida pela fonte, a partir da corrente total, entretanto, em Castro-Núñez e Castro-Puche (2012) segue-se outro caminho e calcula-se a potência total adicionando-se as potências indutiva e capacitiva do multivetor $M S=M L+M C$, o qual, pelo princípio da superposição, deveria conduzir ao mesmo resultado obtido no domínio do tempo, o que não ocorreu, conforme apresentado na Tabela 1 acima.

Apenas para ilustrar-se a diferença, apresenta-se abaixo os resultados para o multivetor $M S=M L+M C$, utilizando-se as transformações propostas neste trabalho:

$$
\begin{aligned}
& \boldsymbol{M}_{L}=\left(\boldsymbol{V}_{1}+\boldsymbol{V}_{3}\right) \cdot\left(\boldsymbol{I}_{L(w)}^{*}+\boldsymbol{I}_{L(3 w)}^{*}\right) \\
& \boldsymbol{M}_{L}=\left(-100 \sigma_{2}-25 \sigma_{6}\right) \cdot\left(\frac{+5700 \sigma_{1}}{32}+\frac{+475 \sigma_{5}}{32}\right) \\
& \boldsymbol{M}_{L}=\frac{-57 \cdot 10^{4}}{32} \sigma_{2} \sigma_{1}-\frac{47500}{32} \sigma_{2} \sigma_{5}- \\
& \frac{25 \cdot 5700}{32} \sigma_{6} \sigma_{1}-\frac{25 \cdot 475}{32} \sigma_{6} \sigma_{5}
\end{aligned}
$$

Confirma-se, portanto, a ocorrência de quatro parcelas distintas no multivetor potência.

$$
\begin{aligned}
& \boldsymbol{M}_{C}=\left(\boldsymbol{V}_{1}+\boldsymbol{V}_{3}\right) \cdot\left(\boldsymbol{I}_{C(w)}^{*}+\boldsymbol{I}_{C(3 w)}^{*}\right) \\
& \boldsymbol{M}_{C}=\left(-100 \sigma_{2}-25 \sigma_{6}\right) \cdot\left(\frac{-4900 \sigma_{1}}{32}+\frac{-3675 \sigma_{5}}{32}\right) \\
& \boldsymbol{M}_{C}=\frac{49 \cdot 10^{4}}{32} \sigma_{2} \sigma_{1}+\frac{367500}{32} \sigma_{2} \sigma_{5}+ \\
& \frac{25 \cdot 4900}{32} \sigma_{6} \sigma_{1}+\frac{25 \cdot 3675}{32} \sigma_{6} \sigma_{5}
\end{aligned}
$$


Adicionando-se algebricamente as quatro parcelas de mesma natureza nos multivetores acima, obtém-se:

$$
\begin{aligned}
& \boldsymbol{M}_{S}=\boldsymbol{M}_{L}+\boldsymbol{M}_{C} \\
& \boldsymbol{M}_{S}=-2500 \sigma_{2} \sigma_{1}+10^{4} \sigma_{2} \sigma_{5}-625 \sigma_{6} \sigma_{1}+2500 \sigma_{6} \sigma_{5}
\end{aligned}
$$

Obtendo-se o mesmo resultado alcançado em (3.2.13) e que está coerente com o resultado no domínio do tempo.

Logo, o multivetor potência obtido em Castro-Núñez e Castro-Puche (2012), e transcrito abaixo:

$$
\boldsymbol{M}_{S}=-5000 \sigma_{1} \sigma_{2}-10625 \sigma_{3} \sigma_{4}
$$

Apresenta apenas duas parcelas distintas, quando o domínio do tempo e o domínio de Clifford, com a transformação e operador de rotação propostos neste trabalho, resultam em quatro parcelas distintas.

Portanto, quando comparadas ao domínio do tempo, as transformações propostas em Castro-Núñez e Castro-Puche (2012) não são suficientes para discriminar de forma inequívoca as distintas parcelas de potência, resultando então, em uma potência aparente que diverge da potência aparente no domínio do tempo.

\section{CONCLUSÕES}

Com a transformação e operador de rotação propostos neste trabalho, fica evidente a capacidade da álgebra geométrica de Clifford em absorver completamente a álgebra dos números complexos e, portanto, estender a análise de circuitos elétricos monofásicos em regime não senoidal de forma simples e eficaz.

A forma proposta neste trabalho para a transformação e operador de rotação, estendem o conceito de Steinmetz (1897), de sistemas senoidais, para sistemas monofásicos em regime não senoidais, de forma inequívoca e imediata, o que pode não acontecer em outras propostas, onde os resultados de potência no domínio de Clifford não correspondem aos resultados de potência no domínio do tempo, visto que, a estratificação das parcelas nas bases do sistema (sigmas) não se apresentam coerentes.

O resultado das potências no domínio do tempo é alcançado no domínio de Clifford, porém, em função da transformação e operador de rotação propostos neste trabalho, com um esforço de cálculo 
incomparavelmente menor que o domínio do tempo, inclusive, não sendo necessário recorrer a operações trigonométricas.

Neste trabalho buscou-se apresentar a fundamentação teórica necessária de ambos os domínios, bem como, demonstrar todas as etapas de cálculo necessárias para o completo entendimento da passagem do domínio do tempo para o domínio de Clifford, objetivando esclarecer este assunto ainda pouco difundido.

\section{AGRADECIMENTOS}

À Fundação de Amparo à Pesquisa do Estado da Bahia - FAPESB pela concessão da bolsa de estudos, tornando possível a realização deste trabalho. 


\section{REFERÊNCIAS}

Akagi, H., Y. Kanazawa and A. Nabae, (1983), "Generalized Theory of the Instantaneous Reactive Power in Three- Phase Circuits," IPEC - International Power Electronics Conference, Tokyo, pp. 1375-1386.

Budeanu, C. I. (1927), "Puissances Reactives et Fictives," Institute Romain de Energie, no. 2.

Castilla, M., Juan Carlos Bravo, M. Ordóñez, and Juan Carlos Montaño, (2008),"Clifford Theory A Geometrical Interpretation of Multivectorial Apparent Power" IEEETransactions On Circuits and Systems-I: Regular Papers, Vol. 55, No. 10, November

Castro-Núñez, M., (2013), 'The use of geometric algebra in the analysis of non-sinusoidal networks and the construction of a unified power theory for single phase systems - a paradigm shift', University of Calgary

Castro-Núñez, M., R. Castro-Puche, (2012), "Advantages of Geometric Algebra Over Complex Numbers in the Analysis of Networks With Nonsinusoidal Sources and Linear Loads," IEEE Transactions On Circuits and Systems-I: Regular Papers, Vol. 59, No. 9, September.

Castro-Núñez, M., Londoño-Monsalve, D., Castro-Puche, R. (2019), "Theorems of compensation and Tellegen in non-sinusoidal circuits via geometric álgebra", The Journal of Engineering, Vol. 2019 Iss. 4, pp. 3409-3417.

Chappell et al. (2014), "Geometric Algebra for Electrical and Electronic Engineers" Proceedings of the IEEE, Vol. 102, No. 9, September.

Czarnecki, L. S. (1988), "Orthogonal Decomposition of the Currents in a 3-phase Nonlinear Asymmetrical Circuit with a Nonsinusoidal Voltage Source," IEEE Transaction on Instrumentation and Measurement, vol. 1, no. 37, pp. 30-34.

Fryze, S. (1932), "Wirk-, Blind- und Scheinleistung in Elektrischen Stromkreisen mit Nichtsinusförmigem Verlauf von Strom und Spannung," ETZ-A Elektrotech Zeitschrift, vol. 53, no. 25, pp. pp. 596-599, 625-627,700-702.

Hestenes, D., Sobczyk, G. (1984), "Clifford Algebra to Geometric Calculus - A Unified Language for Mathematics and Physics", D. Reidel Publishing Company, Dordiecht, Holland.

IEEE Standard Definitions for the Measurement of Electric Power Quantities Under Sinusoidal, Nonsinusoidal, Balanced, or Unbalanced Conditions, IEEE Std 1459- 2010 (Revision of IEEE Std 14592000), pp. 1 -40, 19March 2010.

Jancewicz, B. (1988), Multivectors and Clifford Algebra in Electrodynamics. Singapore: World Science.

Shepherd, W., Zakikhani, P. (1972), "Suggested Definitions of Reactive Power for Nonsinusoidal Systems," IEEE Proceedings, vol. 9, no. 119, pp. 1361-1362.

Steinmetz, C. P. (1897), Theory and Calculation of Alternating Current Phenomena. New York: McGraw- Hill. 


\section{Capítulo 6}

\section{doi $10.37423 / 211105064$}

\section{COMPARAÇÃO DE CLASSIFICADORES NA ANÁLISE DE GASES DISSOLVIDOS}

José Jorge de Oliveira Neto

George Victor Rocha Xavier

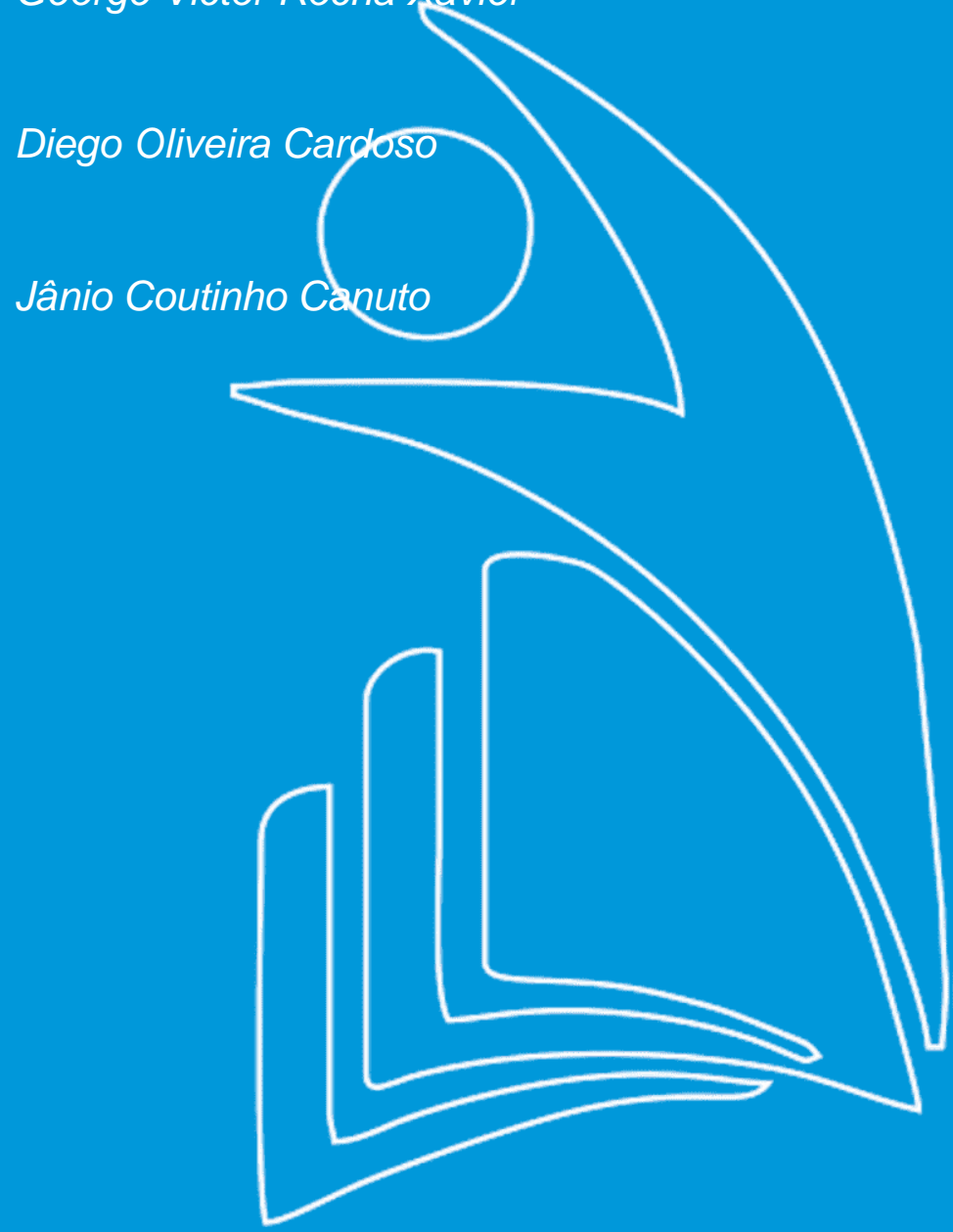

Universidade Federal de Sergipe

Universidade Federal de Gampina Grande

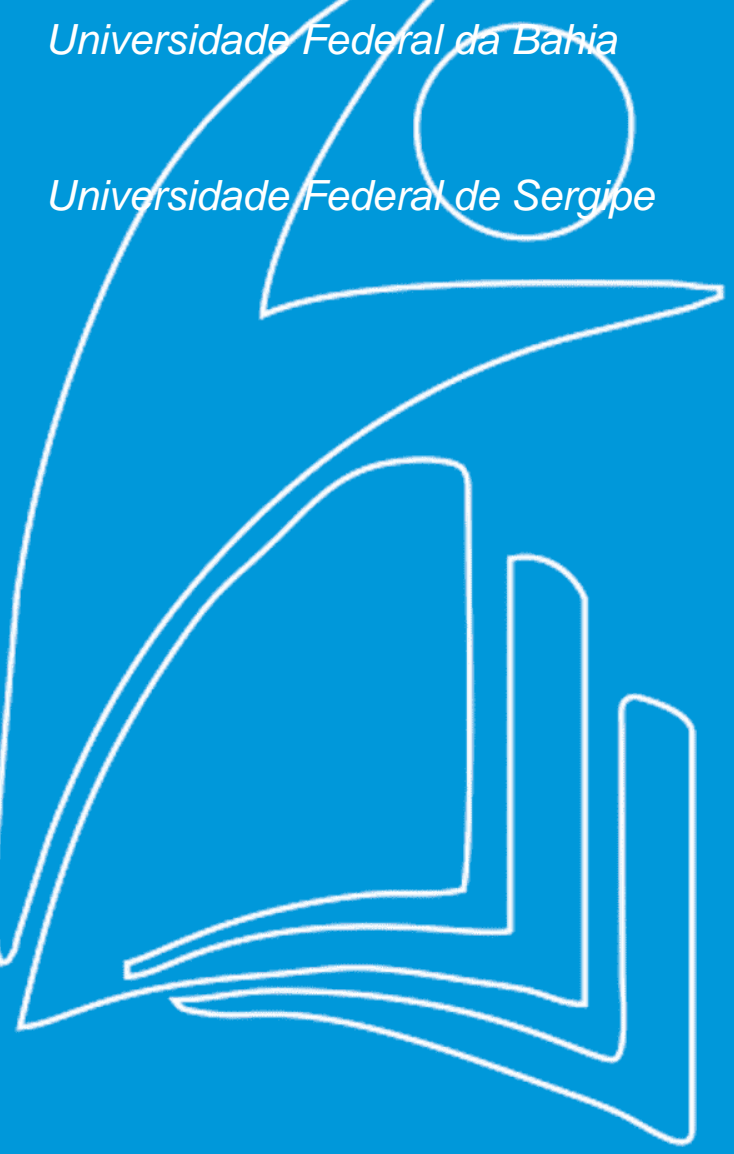


Resumo: A Análise de Gases Dissolvidos (AGD) 'e uma poderosa técnica para diagnóstico de falhas incipientes em transformadores isolados a óleo. A utilização de classificadores inteligentes tem se tornado uma pr'atica cada vez mais recorrente nesta área, sendo a Rede Neural Artificial (RNA) um dos algoritmos mais populares. Neste trabalho, busca-se comparar três classificadores de rápida implementação com a RNA, método já estabelecido, porém mais complexo. Os classificadores são: o k-ésimo vizinho mais próximo $(K N N)$, um baseado no Discriminante Linear de Fisher e um na métrica de Mahalanobis. Dentre esses, os melhores resultados foram obtidos pelo KNN e a RNA, com $81,97 \%$ e $85,25 \%$ de acertos durante a validação, seguidos pelo Discriminante de Fisher e Mahalanobis, ambos com 70,05\%. Todos os classificadores tiveram um bom desempenho, mostrando superioridade a algumas técnicas clássicas como a de Rogers e Doernenburg para os dados analisados. Dessa forma, os três algoritmos se mostraram uma alternativa `a RNA, com implementação mais rápida e com menor peso computacional, cabendo dar destaque ao KNN.

Palavras-chaves: análise de Gases Dissolvidos; Reconhecimento de Padrões; Falhas em Transformadores; Discriminante Linear de Fisher; Redes Neurais Artificiais; Comparação de Classificadores. 


\section{INTRODUÇÃO}

Os transformadores são de extrema importância para o sistema elétrico. Naturalmente, devido ás consequências graves associadas à sua falha, como perda de equipamentos, multas e risco `a segurança, esse componente se torna centro de diversas pesquisas para garantir o seu funcionamento em condições normais. Por meio de diferentes técnicas de monitoramento, busca-se o momento ideal para sua manutenção em que os defeitos ainda são incipientes (Abu-Elanien and Salama, 2010). Dentre as diferentes técnicas, a Análise de Gases Dissolvidos (AGD) é uma das mais tradicionais, sendo estudada há muitos anos, remontando á primeira guerra mundial (Kelly, 1980).

A AGD possui diversas ferramentas que auxiliam na realização do diagnóstico, muitas delas dispostas em guias e normas baseadas em investigações estatísticas de uma extensa base de dados ao longo dos anos, como os métodos de Rogers, Doernenburg, Duval, dentre outros (Std- C57.104, 2009; Duval, 2006). Aliada a estas ferramentas, diversos sistemas inteligentes vêm sendo desenvolvidos, comumente utilizando Redes Neurais Artificiais (RNA), Lógica Fuzzy e Máquina de Vetores de Suporte (Bakar et al., 2014; Senoussaoui et al., 2018; Zirbes et al., 2005). No entanto, tais algoritmos possuem maior custo computa- cional devido ao ajuste de par^ametros necessários para seu funcionamento ideal, o que por sua vez demanda tempo de acordo com o poder computacional disponílvel. Como alternativa, discriminantes lineares podem ser aplicados nesse tipo de tarefa de forma eficiente, seja utilizando tal classificador de forma independente (Zaini, 2019) ou com-binada a outros algoritmos (Liang et al., 2008). Quando utilizado de forma independente, são construídos a partir de cálculos e operações matriciais simples, possibilitando uma implementação direta. Desta maneira, numa situação de urgência em que tempo e poder computacional não estejam a disposição, tais classificadores podem auxiliar na avaliação do equipamento ao lado de outras técnicas, por exemplo.

Neste trabalho, é realizada uma comparação de quatro classificadores, a saber: RNA, k-ésimo vizinho mais próximo, Discriminante Linear de Fisher e um discriminante baseado na métrica Mahalanobis. Assim, busca-se investigar o quão eficiente seria a aplicação destas técnicas comparadas a um classificador bem estabelecido como a RNA.

\section{METODOLOGIA}

Para o desenvolvimento deste estudo foi utilizado o conjunto de dados disponibilizado por Morais et al. (2004). Essa base de dados é composta por três conjuntos, dos quais dois são analisados 
neste trabalho: (A) disponibilizado pelo Centro de Pesquisa em Energia Elétrica (Cepel) e (B) disponibilizadas pelo International Electrote-chnical Commission (IEC). O conjunto A é constituído pela concentração de gases dissolvidos em transformadores com e sem comutadores de carga (On Load Tap Changer - OLTC). O conjunto B é puramente composto por equipamentos sem comutadores. Cada amostra contém a concentração em ppm de cinco gases $\left(\mathrm{H}_{2}, \mathrm{CH}_{4}, \mathrm{C}_{2} \mathrm{H}_{2}, \mathrm{C}_{2} \mathrm{H}_{4}\right.$, $\left.\mathrm{C}_{2} \mathrm{H}_{6}\right)$, com uma rotulação de acordo com as suas condições, a saber:

- Conjunto A (Cepel) - 83 amostras de Condições Normais $(N), 80$ de Falha Térmica $(T)$ e 61 de Falha Elétrica $(E)$;

- Conjun B (IEC) - 16 amostras de Condições Normais $(N), 14$ de Falha Térmica $(T)$ e 22 de Falha Elétrica $(E)$.

Dois experimentos foram realizados com diferentes objetivos. O primeiro experimento, buscou comparar o desempenho dos classificadores entres si. Para tanto, uniu-se o Conjunto A (após pré processamento) e B separando $70 \%$ para treinamento e 30\% para validação. O segundo experimento utilizou o Conjunto A para treinamento e o B para validação. Neste ponto, o intuito é analisar o desempenho dos algoritmos com relação aos métodos clássicos de Rogers e Doernenburg aplicados aos dados IEC.

\subsection{PRÉ-PROCESSAMENTO}

As amostras passaram por um pré processamento, etapa em que as entradas são normalizadas. Durante a implementação direta dos classificadores no conjunto de dados $A$, foi percebido que a presença de dois tipos de transformadores poderia influenciar nas decisões devido as suas diferenças operacionais. Dessa forma, realiza-se um procedimento de agrupamento dos dados buscando obter um conjunto mais puro. O algoritmo utilizado foi o k-means, para k igual 2, implementada na classe de amostras N e T, em que os dois tipos de transformadores se tornam mais evidentes. Após a separação, observou-se um grupo de dados com concentrações de hidrogênio relativamente altas quando comparadas aos demais gases, o que foi interpretado como um indicativo de arco elétrico na operação dos transformadores. Cabe ressaltar que o hidrogênio é um dos gases chave de falhas elétricas como descargas parciais e formação de arco, como relatado no Guia IEEE (Std- C57.104, 2009). Ademais, a formação de arco elétrico é comum na operação normal dos transformadores OLTC (Duval, 2008). Nas Figuras 1 e 2 é possível observar a média dos dois grupos obtidos para as classes $\mathrm{N}$ e $\mathrm{T}$, respectivamente. Dessa forma, um novo conjunto de dados A, sem comutadores de carga, 'e formado, composto por 38 amostras N , 52 T e $61 \mathrm{E}$. 


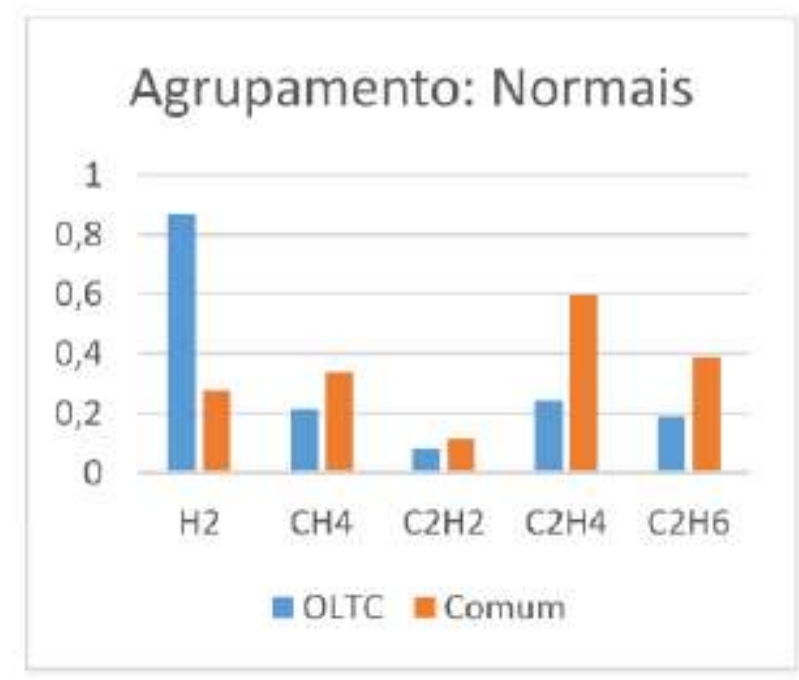

Figura 1. Média das concentrações na classe de dados N.

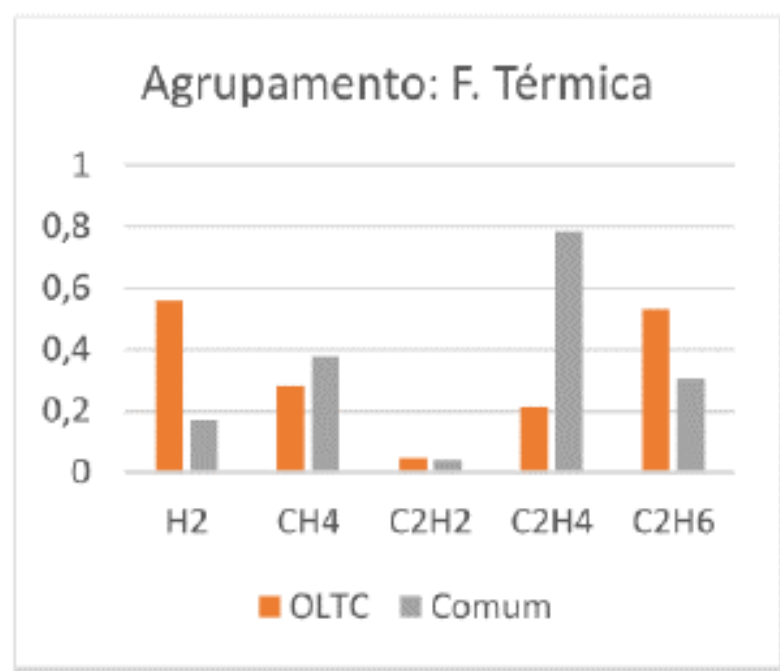

Figura 2. Média das concentrações na classe de dados T.

A partir desse ponto, inicia-se o treinamento dos modelos. No Experimento 1, uni-se o novo conjunto A e o conjunto $B$ e se divide $70 \%$ para treinamento e o restante para validação. No Experimento 2, o conjunto A 'e utilizado para o treinamento e o conjunto B para validação. Os algoritmos de reconhecimento de padrões foram implementados via software MATLAB. A avaliação é realizada por meio de tabelas de acurácia e de confusão dos classificadores. Ademais, uma representação gráfica dos dados em duas dimensões também 'e realizada utilizando Análise de Discriminante Linear (ADL) (Marcialis and Roli, 2002) para redução de dimensão. 


\subsection{CLASSIFICADOR 1}

O Classificador 1 consiste numa cascata de outros dois baseados na função discriminante linear de Fisher. Tal função é uma combinação linear dos dados, buscando maximizar a separação entre duas populações (Varella,2008). A função discriminante é dada pela equação (1), enquanto o ponto médio entre as duas populações é dado pela equação (2):

$$
\begin{gathered}
D(x)=\left[\mu_{1}-\mu_{2}\right] \cdot \Sigma^{-1} \cdot x=w \cdot x \\
m=\frac{1}{2}\left[\mu_{1}-\mu_{2}\right] \cdot \Sigma^{-1} \cdot\left[\mu_{1}+\mu_{2}\right]
\end{gathered}
$$

em que $x$ é a amostra a ser classificada, $\mu_{i}$ é a média da classe $i, \Sigma$ é a matriz de covariância das amostras. A amostra $x$ é classificada de acordo com o valor de $D(x)$, caso esse seja maior ou igual a $m, x$ é classificado como pertencente a população 1 , caso contrário, pertence a população 2 .

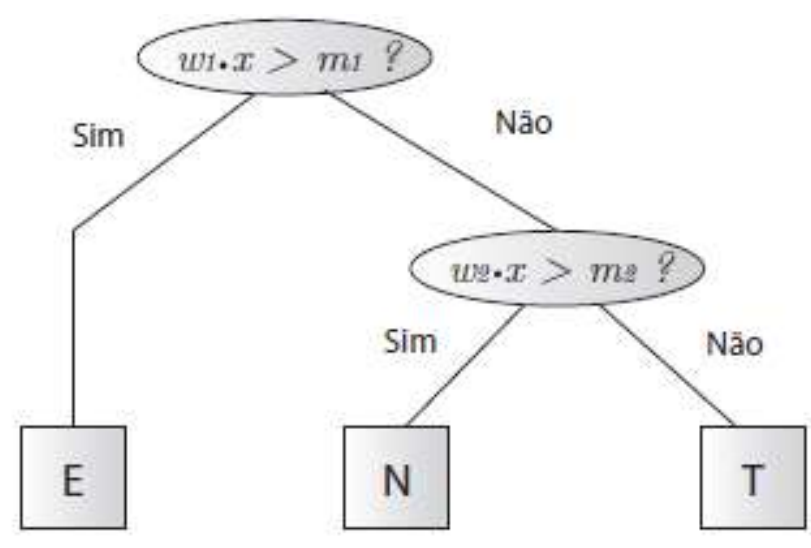

Figura 3. Cascata utilizada na classificação.

O algoritmo desenvolvido realiza a primeira separação em duas populações de amostras, uma composta por amostras E e outra por amostras N e T. Em seguida, separam-se as classes $\mathrm{N}$ e T. Na Figura 3 pode ser visto o fluxograma da cascata utilizada. A escolha da separação foi realizada observando a disposição dos dados, onde foi reconhecido uma maior distinção das falhas elétricas das demais. Para auxiliar a visualização, foi feita uma redução de dimensão, de 5 para 2, utilizando ADL e pode ser observada na Figura 4.

Após o treinamento, o classificador é submetido á validação, onde é possível observar seu desempenho diante de novos dados (também dispostos nas mesmas três classes, N, T e E). 


\subsection{CLASSIFICADOR 2}

O segundo classificador a ser implementado _e baseado na distância de Mahalanobis. Esse classificador realiza a discriminação das diferentes classes de acordo com a métrica descrita em (3):

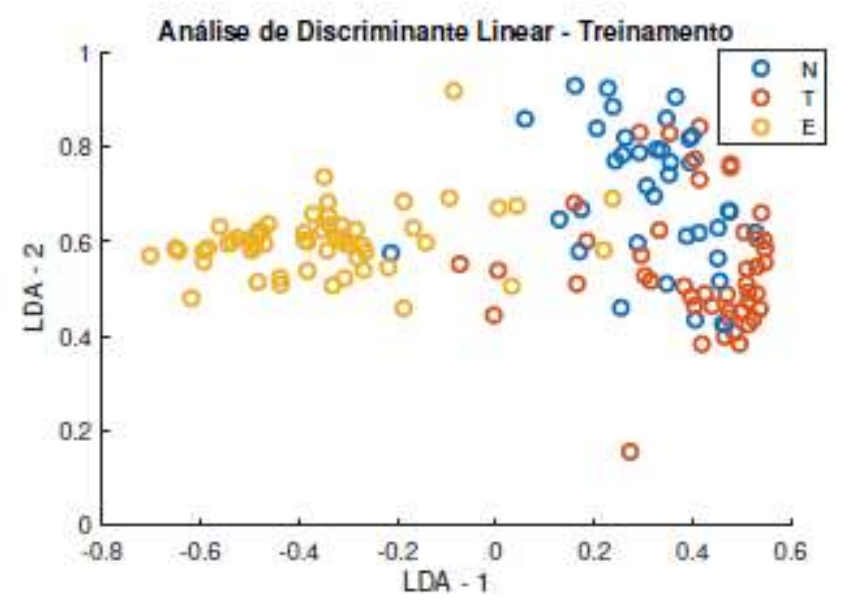

Figura 4. análise gráfica da fase de treinamento.

$$
D m_{i}=\sqrt{\left(x-\mu_{i}\right) \Sigma^{-1}\left(x-\mu_{i}\right)}
$$

em que x é a amostra a ser classificada, $\mu_{i}$ é a média da classe $i, \Sigma$ é a matriz de covariância das amostras.

A amostra x é classificada de acordo com o menor valor de Dmi, pertencendo ao grupo mais próximo de acordo com essa métrica. Supondo um conjunto de amostras distribuídas como uma gaussiana, esse tipo de métrica pode oferecer uma melhor delimitação dos conjuntos que a distância euclidiana, por exemplo. Adicionalmente, possui uma implementação simples e rápida.

\subsection{CLASSIFICADOR 3}

A terceira metodologia utilizada para classificação das amostras contou com um algoritmo mais robusto conhecido como Redes Neurais Artificiais. A rede neural busca emular o aprendizado a partir do modelo do neurônio (Figura 5). Assim como o neurônio humano, o modelo exta sujeito a diferentes estímulos, os quais são amplificados ou atenuados de acordo com os pesos sinápticos w, inibidos ou não pelos vieses b. Esses estímulos são capazes de provocar determinado nível de excitação, representada no modelo pela função de ativação g(:). A partir da organização, do número de neurônios e das técnicas utilizadas para aprendizado é possível estruturar diferentes arquiteturas. 
A arquitetura utilizada neste trabalho utiliza uma camada escondida, conforme a Figura 6 , em que $n=$ $5, \mathrm{k}=90 \mathrm{em}=3$.

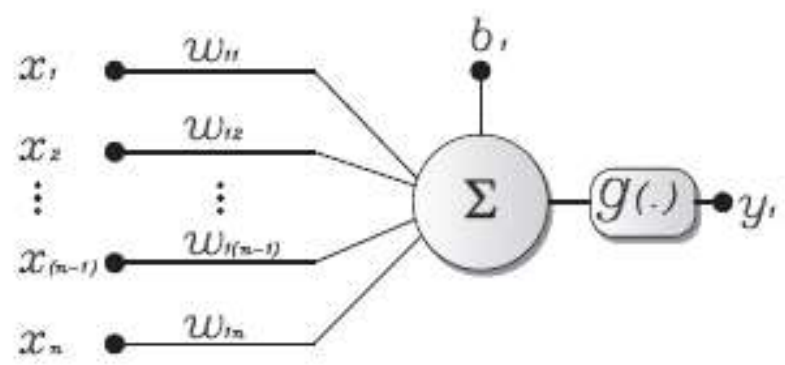

Figura 5. Modelo do neurônio artificial.

O treinamento do algoritmo foi realizado após a separação do conjunto A (mencionada na subseção anterior). A rede tem como entrada as cinco concentrações de gases e como saída um vetor de três dimensões. As amostras normais apresentam sua saída como $[1,0,0]$, as de falha elétrica $[0,1,0]$ e térmica $[0,0,1]$. Tais saídas são obtidas reconhecendo o máximo valor do vetor y.

Após a realização de diferentes testes variando o número de neurônios na camada escondida se obteve a configuração apresentada na Tabela 1. Como método de treinamento,

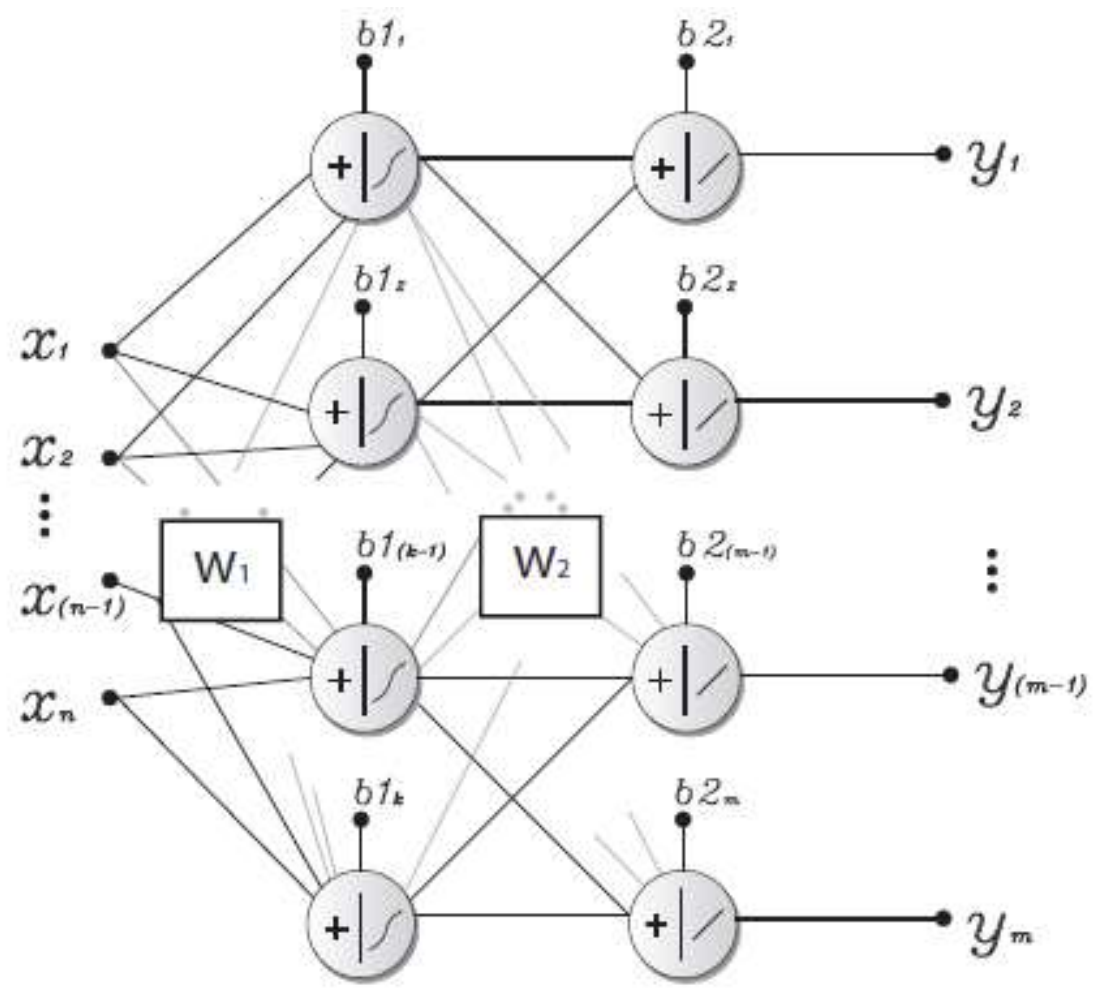

Figura 6. Arquitetura de RNA utilizada. 
Tabela 1. Configuração da RNA implementada.

\begin{tabular}{cc}
\hline Número de Épocas & 800.000 \\
\hline Número de Neurônios (camada escondida) & 90 \\
\hline Número de Camadas & 2 \\
\hline Função de Ativação 1 & Tangente Hiperbólica \\
\hline Função de Ativação 2 & linear \\
\hline Taxa de Aprendizado & 0,001 \\
\hline
\end{tabular}

utilizou-se o backpropagation (Theodoridis and Koutroumbas, 1999) com gradiente estocástico, objetivando um ajuste dos parâmetros uniforme com relação a todos os pontos. Como critério de parada foi utilizado o número de épocas $(800.000)$ e o valor da maior atualização dos parâmetros (pesos sinápticos e vieses). Quando a maior atualização fosse inferior a $0,310 \times 1^{5}$. A etapa de validação se deu de maneira análoga ao Classificador 1.

\subsection{CLASSIFICADOR 4}

O quarto classificador é baseado no K-ésimo Vizinho mais Proximal, do inglês K-Nearst Neighborhood - KNN. Esse algoritmo rotula a amostra de teste de acordo com a classe mais frequente dentre as $\mathrm{k}$ mais próximas, utilizando algum tipo de métrica para avaliar a distância. Nesse trabalho, o valor de $\mathrm{k}$ utilizado foi 10, enquanto que número das amostras de cada classe também foi limitado ao tamanho da menor classe.

\section{RESULTADOS E DISCUSSÕES}

\subsection{EXPERIMENTO 1}

Durante a construção dos classificadores, foram observados os seus desempenhos por meio da taxa de acertos na fase de treinamento e validação. Nas Tabelas 2 e 3 se encontram listados a acurácia de cada um dos classificadores com relação a cada classe e o total.

No intuito de mensurar detalhadamente o desempenho dos classificadores, foram montadas as Matrizes de Confusão de cada um, dadas pelas Tabelas 4 a 7. Considerando os 
Tabela 2. Parcela de Acertos durante a fase de treinamento.

\begin{tabular}{c|c|c|c|c}
\hline & $N(\%)$ & $T(\%)$ & $E(\%)$ & Total $(\%)$ \\
\hline Clasf. 1 & 65,79 & 71,74 & 91,38 & 78,17 \\
\hline Clasf. 2 & 65,79 & 71,74 & 89,00 & 77,46 \\
\hline Clasf. 3 & 73,68 & 78,26 & 96,55 & 84,51 \\
\hline Clasf. 4 & 73,68 & 78,26 & 89,67 & 81,69 \\
\hline
\end{tabular}

Tabela 3. Parcela de Acertos durante a fase de validação.

\begin{tabular}{c|c|c|c|c}
\hline & $N(\%)$ & $T(\%)$ & $E(\%)$ & Total $(\%)$ \\
\hline Clasf. 1 & 50,00 & 75,00 & 96,00 & 77,05 \\
\hline Clasf. 2 & 50,00 & 75,00 & 96,00 & 77,05 \\
\hline Clasf. 3 & 62,50 & 90,00 & 96,00 & 85,25 \\
\hline Clasf. 4 & 68,75 & 80,00 & 92,00 & 81,97 \\
\hline
\end{tabular}

Dados de forma binária, em condições normais ou condições de falha ( $T$ e $E$ ), é possível realizar algumas observações.

Os classificadores 1, 2 e 4 tiveram 11,11\% das amostras faltosas classificadas como normais (falsos positivos). Nesse tipo de problema, a classificação de um transformador defeituoso como saudável pode ter consequências graves, trazendo riscos de perda total do equipamento, risco a segurança das equipes de manutenção, etc. Ainda, os classificadores 1 e 2 obtiveram o maior número de falsos negativos, $50,00 \%$ das amostras normais classificadas como falha.

Essa condição pode ser prejudicial ao sistema, acarretando intervenções desnecessárias.

Tabela 4. Matriz de Confusão do Classificador 1.

\begin{tabular}{|c|c|c|c|c|}
\hline & \multicolumn{4}{|c|}{ Clasf. 1} \\
\hline \multirow{4}{*}{ 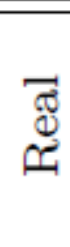 } & & $N$ & $\bar{T}$ & $E$ \\
\hline & $N$ & 8 & 6 & 2 \\
\hline & $T$ & 5 & 15 & 0 \\
\hline & $E$ & 0 & 1 & 24 \\
\hline
\end{tabular}


Tabela 5. Matriz de Confusão do Classificador 2.

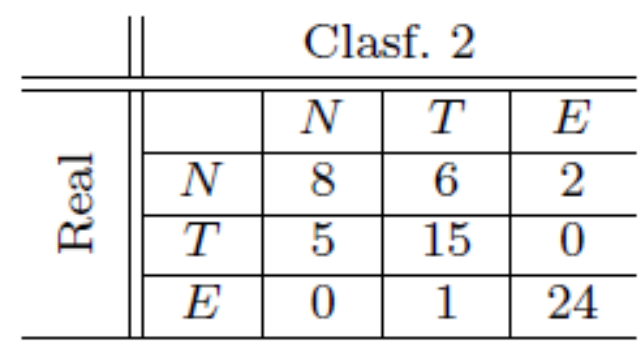

Tabela 6. Matriz de Confusão do Classificador 3.

\begin{tabular}{|c|c|c|c|c|}
\hline & \multicolumn{4}{|c|}{ Clasf. 3} \\
\hline \multirow{4}{*}{ ๘ే } & & $N$ & $T$ & $E$ \\
\hline & $N$ & 10 & 4 & 2 \\
\hline & $T$ & 2 & 18 & 0 \\
\hline & $E$ & 0 & 1 & 24 \\
\hline
\end{tabular}

De modo geral, 0 ideal é que o classificador não possua ou tenha valores reduzidos de ambos, semelhante ao Classificador 3, conforme Tabela 6. A RNA obteve um

Tabela 7. Matriz de Confusão do Classificador 4.

\begin{tabular}{|c|c|c|c|c|}
\hline & \multicolumn{4}{|c|}{ Clasf. 4} \\
\hline \multirow{4}{*}{$\underset{\mathscr{\Phi}}{\widetilde{\varpi}}$} & & $N$ & $T$ & $E$ \\
\hline & $N$ & 11 & 3 & 2 \\
\hline & $T$ & 4 & 16 & 0 \\
\hline & $E$ & 1 & 1 & 23 \\
\hline
\end{tabular}

menor número de falsos positivos diante dos demais, cerca de 4,44\% na validação, e a melhor acurácia dentre os quatro, 85,25\%. Em seguida, o KNN apresentou $81,97 \%$ de acurácia nesta etapa, se posicionando como o segundo colocado.

O Classificador 4 apresentou o menor valor de falsos negativos, 3,12\%. Cabe ressaltar que, dentre os quatro classificadores, a RNA é sem dúvidas o que exige maior esforço computacional. Tal algoritmo demanda tempo durante seu treinamento, necessitando de diversas iterações, enquanto os demais, por serem técnicas baseadas em estatísticas, são de rápida implementação, consistindo na execução de pequenas decisões. Ademais, os Classificadores 1, 2 e 4 apresentaram taxas de acerto próximas da RNA, tornando essas ferramentas atraentes em situações de pouco recurso computacional e tempo disponíveis. 


\subsection{EXPERIMENTO 2}

Ainda é possível comparar os resultados obtidos neste estudo com os de métodos clássicos disponíveis na literatura, como Rogers e Doernenburg (Std-C57.104, 2009). Morais et al. (2004) trazem no seu trabalho tabelas com a acurácia dessas técnicas perante os dados disponibilizados pela IEC.

Dessa forma, realizou-se o treinamento dos quatro classificadores apenas com os dados Cepel (Tabela 8). A Tabela 9 é uma adaptação listando os resultados de ambos métodos, onde se observa o desempenho baixo com relação aos classificadores trazidos neste trabalho. Os autores também salientam quanto ao índice de falsos positivos no método Doernenburg, em torno de $13,46 \%$ de todo o conjunto, $36,84 \%$ sobre o total de erros. O método de Rogers não foi capaz de identificar certas amostras, alcançando uma parcela de $32,69 \%$ de amostras não identificadas.

Tabela 8. Parcela de Acertos durante a fase de treinamento- Dados Cepel.

\begin{tabular}{c|c|c|c|c}
\hline & $N(\%)$ & $T(\%)$ & $E(\%)$ & Total $(\%)$ \\
\hline Clasf. 1 & 52,63 & 71,15 & 91,80 & 74,83 \\
\hline Clasf. 2 & 50,00 & 71,15 & 88,52 & 72,85 \\
\hline Clasf. 3 & 63,15 & 78,84 & 95,08 & 81,45 \\
\hline Clasf. 4 & 63,15 & 82,69 & 88,52 & 80,13 \\
\hline
\end{tabular}

Na Tabela 9 é possível notar o alto desempenho dos classificadores com relação ao treinamento. Isso pode ser explicado devido a signinicativa sobreposição dos dados Cepel (Figura 7), não tão evidente nos dados IEC (Figura 8). A superposição tende a dificultar a tarefa dos classificadores, principalmente se tratando de métodos lineares. Desta maneira, ao serem aplicados em um conjunto de dados onde as classes estão mais separadas, o desempenho tende apresentar melhores resultados. Ainda neste experimento, o KNN se mostrou superior a RNA durante a validação, atingindo 96,15\%. 
Comparação De Classificadores Na Análise De Gases Dissolvidos

Tabela 9. Parcelas de Acertos de métodos clássicos diante dos dados IEC apresentadas por Morais et al. (2004).

\begin{tabular}{c|c|c|c|c}
\hline & $N(\%)$ & $T(\%)$ & $E(\%)$ & Total $(\%)$ \\
\hline Rogers & - & 86,36 & 64,28 & 53,84 \\
\hline Doern. & 43,75 & 72,73 & 71,43 & 63,46 \\
\hline Clasf. 1 & 93,75 & 71,42 & 100 & 90,38 \\
\hline Clasf. 2 & 87,50 & 71,43 & 100 & 88,46 \\
\hline Clasf. 3 & 93,75 & 78,57 & 100 & 92,31 \\
\hline Clasf. 4 & 100,00 & 85,71 & 100 & 96,15 \\
\hline
\end{tabular}

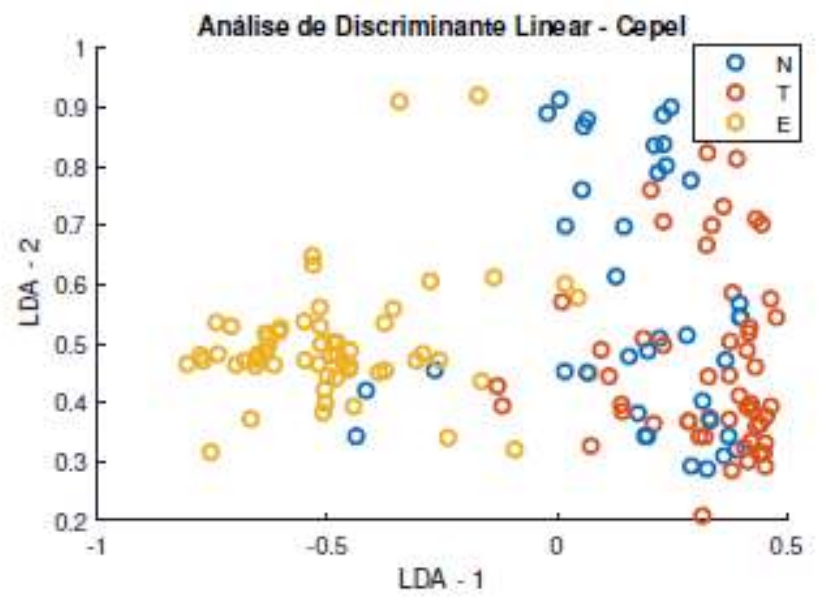

Figura 7. análise gráfica dos dados Cepel.

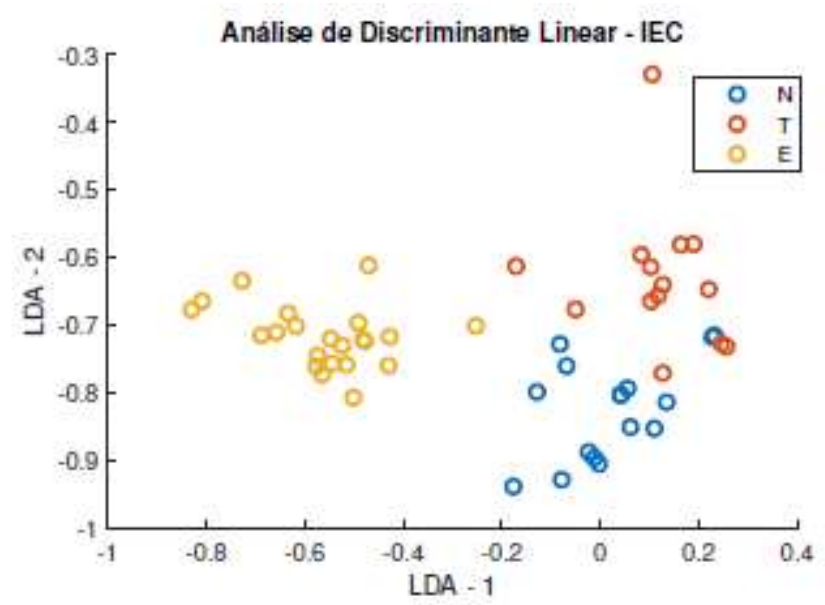

Figura 8. análise gráfica dos dados IEC. 


\subsection{RESULTADOS: PRÉ-PROCESSAMENTO}

Na Tabela 10 se encontram listados os desempenhos de cada classificador antes e após separação dos dados, a qual é realizada no pré-processamento. Todos apresentaram um melhor desempenho quando treinados com o novo conjunto de dados, evidenciando o benefício da metodologia.

Ainda é possível observar que a RNA e o KNN tiveram as alterações mais significativas, saltando de 75,00 para $92,11 \%$ e de 82,69 para $96,15 \%$ respectivamente. Essa melhoria era esperada, dado que as possíveis amostras de transformadores com OLTCs possuem um perfil diferente daqueles que não os possui.

Tabela 10. Acurácia dos classificadores antes e depois da separação de dados.

\begin{tabular}{c|c|c|c|c}
\hline Clasf. & $1(\%)$ & $2(\%)$ & $3(\%)$ & $4(\%)$ \\
\hline \hline Antes & 86,54 & 82,69 & 75,00 & 82,69 \\
\hline Depois & 90,38 & 88,46 & 92,11 & 96,15 \\
\hline
\end{tabular}

\section{CONCLUSÃO}

A AGD é uma das técnicas para diagnóstico de falhas incipientes mais estabelecida ao longo dos anos. Neste trabalho, foram desenvolvidos e comparados quatro classificadores de falhas de transformadores a partir desse tipo de análise.

O Classificador 1, o qual consiste em dois discriminantes lineares de Fisher em cascata, obteve 78,17\% e $77,05 \%$ de acertos durante o treinamento e validação, respectivamente. 0 segundo classificador, baseado na distância de Mahalanobis, alcançou taxas de acerto de 77,46\% e 77,05\%, treinamento e validação. Ambos apresentaram o maior número de falsos positivos, equipamentos defeituosos classificados como normais, conforme Tabelas 4 e 5. Nesta aplicação é desejável que ocorra o menor número possível desse tipo de erro devido aos riscos associados a não detecção da falha do transformador.

A RNA, Classificador 3, obteve uma acurácia de $84,51 \%$ e $85,25 \%$, treinamento e validação respectivamente. Ade- mais, observou-se valores reduzidos de falsos positivos e negativos, conforme Tabela 6. Dessa maneira, é possível verificar a capacidade desse algoritmo na identificação de falhas na AGD. 
O quarto classificador, $K N N$, apresentou valores próximos a RNA, 81,51\% e $81,97 \%$, treinamento e validação.

Ainda foi observado que todos os classificadores obtiveram resultados superiores á aplicação de técnicas clássicas no conjunto de dados B (IEC) de acordo com o apresentado por Morais et al. (2004). Nesta etapa, o Classificador 4 apresentou uma acurácia superior até mesmo a RNA.

Como pode ser notado, todos os classificadores obtiveram bons desempenhos, dentre os quais a RNA e o KNN se destacaram. Os três classificadores apresentados são de rápida implementação, podendo ser utilizados como uma alternativa com pouco custo computacional, com suas restrições.

\section{AGRADECIMENTOS}

Os autores deste trabalho agradecem a CAPES e a Universidade Federal de Sergipe pelo apoio financeiro e estrutural recebido na realização deste estudo. 


\section{REFERÊNCIAS}

Abu-Elanien, A.E. and Salama, M. (2010). Asset ma- nagement techniques for transformers. Electric power systems research, 80(4), 456-464.

Bakar, N.A., Abu-Siada, A., and Islam, S. (2014). A review of dissolved gas analysis measurement and interpretation techniques. IEEE Electrical Insulation Magazine, 30(3), 39-49.

Duval, M. (2006). Dissolved gas analysis and the duval triangle. TechCon Asia Pacific, Sydney, Australia, $1-20$.

Duval, M. (2008). The duval triangle for load tap changers, non-mineral oils and low temperature faults in transfor- mers. IEEE Electrical Insulation Magazine, 24(6), 22- 29.

Kelly, J.J. (1980). Transformer fault diagnosis by dissolved-gas analysis. IEEE Transactions on Industry Applications, (6), 777-782.

Liang, Y., Sun, X., Liu, Q., Bian, J., and Li, Y. (2008). Fault diagnosis model of power transformer based on combinatorial kfda. In 2008 International Conference on Condition Monitoring and Diagnosis, 956959. IEEE.

Marcialis, G.L. and Roli, F. (2002). Fusion of Ida and pca for face verification. In International Workshop on Biometric Authentication, 30-37. Springer.

Morais, D.R. et al. (2004). Ferramenta inteligente para detecção de falhas incipientes em transformadores baseada na análise de gases dissolvidos no óleo isolante.

Senoussaoui, M.E.A., Brahami, M., and Fofana, I. (2018). Combining and comparing various machinelearning al- gorithms to improve dissolved gas analysis interpretation. IET Generation, Transmission \& Distribution, 12(15), 3673-3679.

Std-C57.104, I. (2009). leee guide for the interpretation of gases generated in oil-immersed transformers. IEEE Std C57.104-2009. doi:10.1109/IEEESTD.2009.4776518.

Theodoridis, S. and Koutroumbas, K. (1999). Pattern recognition and neural networks. In Advanced Course on Artificial Intelligence, 169-195. Springer.

Varella, C.A.A. (2008). Análise multivariada aplicada as ciências agrárias.

Zaini, H.G. (2019). Diagnosis of the power transformer faults based on dga using intelligent classifier. Interna- tional Journal of Engineering Research and Technology, 12(8), 1964-1971.

Zirbes, R., Rolim, J.G., and Zu“rn, H.H. (2005). Me-todologias para avaliação e diagnóstico do estado de isolamentos de papel impregnado com óleo mineral. Sba: Controle \& Automação Sociedade Brasileira de Automa- tica, 16(3), 318-331. 